\title{
DEPRESSÃO POR ENDOGAMIA DOS COMPONENTES DA PRODUÇÃO EM POPULAÇÕES E HÍBRIDOS DE MILHO (Zea mays L.)
}

\author{
RHAINER GLEICO CARDOSO \\ Engenheiro Agrônomo
}

Orientador: Prof. Dr. CLÁUDIO LOPES DE SOUZA JÚNIOR

\begin{abstract}
Dissertação apresentada à Escola Superior de Agricultura "Luiz de Queiroz", da Universidade de São Paulo. para obtenção do título de Mestre em Agronomia, Área de concentração: Genética

Melhoramento de Plantas.
\end{abstract}

PIRACICABA

ESTADO DE SÃO PAULO - BRASIL

MAIO - 1999 
Cardoso, Rhainer Gleico Depressão por endogamia dos componentes da produção em populações e híbridos de milho (Zea mays $\mathbb{L}_{0}$ ). Piracicaba, Dissertação (Mestrado). Escola Superior de Agricultura "Luiz de Queiroz", Universidade de São Paulo. 1999. 134p.

\section{ERRATA \& CORRIGENDA N.1}

p. item linha onde se lê

$\begin{array}{llll}35 & 3.1 .1 & 28 & \text { Empresa brasileira de }\end{array}$ agropecuária (EMBRAPA). . .

$69 \quad 4.3 \quad 6$

$\begin{array}{lll}70 & 4.3 \quad 16\end{array}$

$81 \quad 4.6 \quad 6$
... inferiores . . .

... heterozigótica;

Tais afirmações confirmam os resultados obtidos no presente trabalho para... leia-se

Empresa Brasileira de Pesquisa

Agropecuária (EMBRAPA). . .

. . . superiores . . .

... homozigótica;

Os resultados obtidos no presente trabalho confirmam tais afirmações para . . . 
Dados Internacionais de Catalogação na Publicação (CIP) DIVISĀo DE BIBLIOTECA E DOCUMENTAÇĀO - Campus “Luiz de Queiroz"/USP

\section{Cardoso, Rhainer Gleico}

Depressão por endogamia dos componentes da produção em populaçōes e hibridos de milho (Zea mays L.) / Rhainer Gleico Cardoso. - - Piracicaba, 1999.

$134 \mathrm{p}$.

Dissertaçāo (mestrado) - - Escola Superior de Agricultura Luiz de Queiroz, 1999. Bibliografia.

1. Autofecundaçāo 2. Endogamia 3. Grāo 4. Melhoramento genético vegetal 5. Milho híbrido 6. Populaçāo vegetal 7. Produçāo vegetal I. Título

CDD 633.15 
Pelo apoio, pelo incentivo

e pelo exemplo, a meus pais

OFEREÇO

Aos meus grandes amigos

José Valdir Sartori Filho,

Jonas José Villa Nova e

Ednilson Leite do Amaral 


\section{AGRADECIMENTOS}

A Deus, pelo dom da vida, por cada dia e pela luz no horizonte.

Ao Conselho Nacional Científico e Tecnológico (CNPq) e à Coordenação de Aperfeiçoamento de Pessoal de Nivel Superior (CAPES) pelas bolsas concedidas para a realização deste estudo.

Ao Professor Dr. Cláudio Lopes de Souza Júnior, pela preciosa orientação desde minha iniciação científica até a elaboração deste trabalho, pela compreensão, respaldo, atenção e, acima de tudo, confiança depositada.

Aos Professores do Departamento e Instituto de Genética da ESALQ/USP, pelos ensinamentos e apoio prestados, os quais contribuíram sobremaneira para a minha formação, em especial ao Prof. Dr. Isaías Olivio Geraldi pelas sugestões e críticas.

Aos funcionários do Departamento de Genética da ESALQ/USP, em especial aos técnicos Antônio Jocelino Desidério e Alfredo de Araújo, que colaboraram na execução dos trabalhos de campo, e às secretárias Cândida Vanderléia de Oliveira e Carmem M. S. F. Pilotto pelos inúmeros auxílios.

Às bibliotecárias Silvana Marchizelli Gregório pela revisão das referências bibliográficas e Aparecida Elisabeth dos Santos da Silva pelos seus gentis préstimos no decorrer do curso.

A Antônio Augusto Franco Garcia pelo estímulo durante minha iniciação no melhoramento de plantas e pelos inúmeros auxílios.

Ao colega Nelson da Silva Fonseca Júnior pelos inestimáveis auxílios no desenvolvimento do programa e análises estatísticas usadas neste trabalho.

Aos colegas do curso de Pós-Graduação em Genética e Melhoramento de Plantas pelo companheirismo, em especial a: Paulo Augusto Vianna Barroso, Cláudio Yuji Tsutsumi, Josué Maldonado Ferreira, Ana Cláudia de Carvalho Badan e Ângela Célis de Almeida Lopes.

A Lôide de Jesus Martins pelo incentivo, apoio, amor e carinho.

Finalmente sou grato a todas as pessoas que, embora não mencionadas, contribuíram direta ou indiretamente para a execução deste trabalho. 


\section{SUMÁRIO}

LISTA DE FIGURAS .......................................................................................

LISTA DE TABELAS.......................................................................... vi

RESUMO

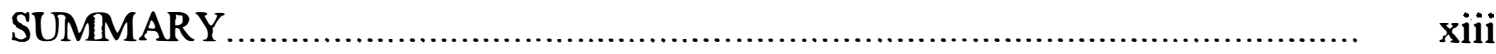

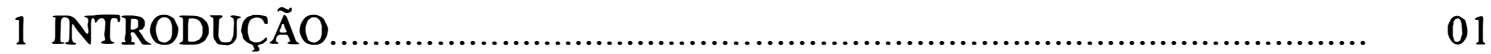

2 REVISÃO DE LITERATURA.................................................................. 04

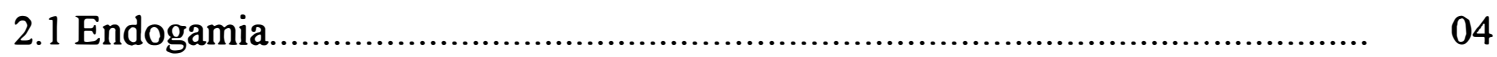

2.2 Depressão por endogamia: Base genética................................................... 06

2.3 Depressão por endogamia em milho ............................................................. 11

2.4 Componentes da produção de grãos........................................................... 26

3 MATERIAL E MÉTODOS ...................................................................... 35

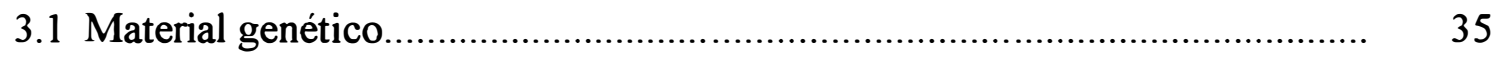

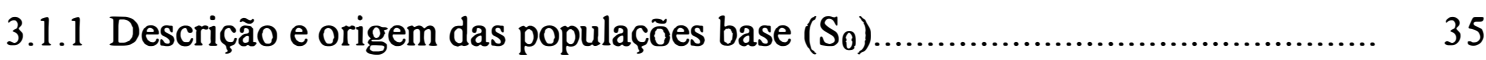

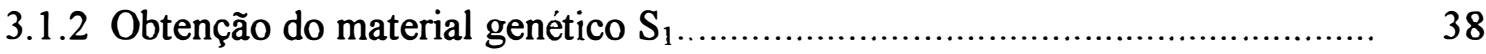

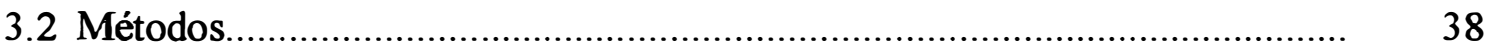

3.2.1 Execução experimental........................................................................... 38

3.2.2 Análises estatístico-genéticas................................................................. 42

3.2.2.1 Análise da variância ao nível de parcela............................................. 42

3.2.2.2 Estimativa da depressão por endogamia .................................................. 47

3.2.2.3 Componentes da produção de grãos........................................................... 48

4 RESULTADOS E DISCUSSÃO............................................................... 51

4.1 Análise geral dos resultados ................................................................. 51 
Página

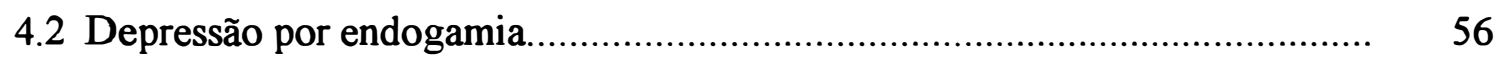

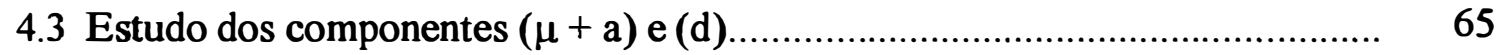

4.4 Componentes da produção de grãos................................................... 71

4.5 Componentes da produção de grãos e sua depressão por endogamia................ 74

4.6 Considerações gerais............................................................................. 80

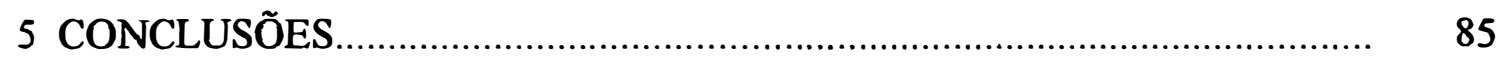

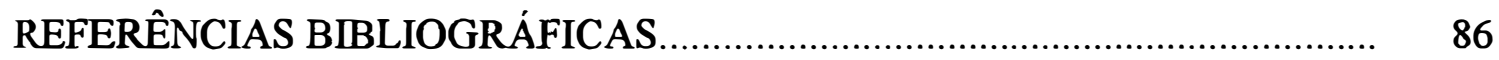




\section{LISTA DE FIGURAS}

1 Médias dos componentes da produção de grãos, para o tipo de material

$\mathrm{S}_{0}$, expressos em porcentagem em relação à produção de grãos, para cada um dos subgrupos dos híbridos e para o grupo das variedades

2 Médias dos componentes da produção de grãos, para o tipo de material $S_{1}$, expressos em porcentagem em relação à produção de grãos, para cada um dos subgrupos dos híbridos e para o grupo das variedades. 106

3 Diferenças porcentuais dos logaritmos dos componentes da produção de grãos entre os tipos de materiais $S_{0}$ e $S_{1}$, expressas em porcentagem em relação à produção de grãos, para cada um dos subgrupos dos híbridos e para o grupo das variedades. 


\section{LISTA DE TABELAS}

Página

1 Estimativas da depressão por endogamia (\%), em relação às médias $S_{0}$, para peso de grãos, em diferentes materiais genéticos do Brasil..

2 Descrição dos materiais genéticos empregados no presente estudo.

3 Esquema de análise de variância conjunta e esperança matemática dos quadrados médios e teste $F$, seguindo uma estrutura em faixas, para um modelo fixo (Kempthorne, 1952)

4 Esquema de análise de variância conjunta seguindo uma estrutura em blocos casualizados e desdobramentos do efeito de cultivares.

5 Médias dos cultivares (populações e híbridos) para os dois tipos de materiais ( $S_{o}$ e $S_{1}$ ), referentes a cada um dos três locais avaliados, para o caráter produção de grãos $(\mathrm{Kg} / \mathrm{ha})$, médias gerais por tipo de material $\left(\mathrm{S}_{O}\right.$ e $S_{1}$ ) e médias dos três locais. Coeficientes de variação das análises individuais e conjunta 109 6 Médias dos cultivares (populações e hibridos) para os dois tipos de materiais ( $\mathrm{S}_{\mathrm{O}}$ e $\mathrm{S}_{1}$ ), referentes a cada um dos três locais avaliados, para o caráter peso de espigas despalhadas $(\mathrm{Kg} / \mathrm{ha})$, médias gerais por tipo de material $\left(\mathrm{S}_{\mathrm{O}}\right.$ e $\left.\mathrm{S}_{1}\right)$ e médias dos três locais. Coeficientes de variação das análises individuais e conjunta.

7 Resumo das análises conjuntas da variância, ao nível de médias das parcelas, para os caracteres produção de grãos $(\mathrm{Kg} / \mathrm{ha})$, peso de espigas despalhadas $(\mathrm{Kg})$, número de espigas, prolificidade (número de espigas/planta) e peso de 500 grãos(g/parcela). 
8 Resumo das análises conjuntas da variância, ao nível de médias das parcelas, para os caracteres diâmetro da espiga $(\mathrm{cm})$, diâmetro do sabugo (cm), número de fileiras, comprimento da espiga $(\mathrm{cm})$, número de grãos por fileira e profundidade do grão $(\mathrm{cm})$

9 Resumo das análises conjuntas da variância, ao nível de médias das parcelas, para os caracteres estande (plantas/parcela), altura da planta (cm), altura da espiga $(\mathrm{cm})$ e posição relativa da espiga (AE/AP).

10 Médias gerais $\left(S_{0}+S_{1}\right)$ dos subgrupos e dos grupos de materiais estudados no presente trabalho

11 Médias dos tratamentos para os materiais $S_{o}$ e $S_{1}$, estimativas da depressão por endogamia em unidades do caráter $(\mathrm{DE})$, porcentagem em relação à população base $(\mathrm{DE} \%)$, contribuição dos locos homozigotos $(\mu+\mathrm{a})$, heterozigotos (d) e relação $(\mu+a) /(d)$ para o caráter peso de espigas (Kg/parcela ).

12 Médias dos tratamentos para os materiais $S_{o}$ e $S_{1}$, estimativas da depressão por endogamia em unidades do caráter $(\mathrm{DE})$, porcentagem em relação à população base (DE\%), contribuição dos locos homozigotos $(\mu+a)$, heterozigotos (d) e relação $(\mu+a) /(d)$ para o caráter produção de grãos ( $\mathrm{Kg} /$ parcela ).

13 Médias dos tratamentos para os materiais $S_{o}$ e $S_{1}$, estimativas da depressão por endogamia em unidades do caráter $(\mathrm{DE})$, porcentagem em relação à população base (DE\%), contribuição dos locos homozigotos $(\mu+a)$, heterozigotos (d) e relação $(\mu+\mathrm{a}) /(\mathrm{d})$ para o caráter peso de 500 grãos (gramas ) 
Página

14 Médias dos tratamentos para os materiais $S_{o}$ e $S_{1}$, estimativas da depressão por endogamia em unidades do caráter (DE), porcentagem em relação à população base $(\mathrm{DE} \%)$, contribuição dos locos homozigotos $(\mu+\mathrm{a})$, heterozigotos (d) e relação $(\mu+a) /(d)$ para o caráter altura da planta (cm)

15 Médias dos tratamentos para os materiais $S_{o}$ e $S_{1}$, estimativas da depressão por endogamia em unidades do caráter $(\mathrm{DE})$, porcentagem em relação à população base (DE\%), contribuição dos locos homozigotos $(\mu+a)$, heterozigotos (d) e relação $(\mu+a) /(d)$ para o caráter altura da espiga (cm)

16 Médias dos tratamentos para os materiais $S_{o}$ e $S_{l}$, estimativas da depressão por endogamia em unidades do caráter (DE), porcentagem em relação à população base (DE\%), contribuição dos locos homozigotos $(\mu+a)$, heterozigotos $(d)$ e relação $(\mu+a) /(d)$ para o caráter posição relativa da espiga.

17 Médias dos tratamentos para os materiais $S_{o}$ e $S_{1}$, estimativas da depressão por endogamia em unidades do caráter (DE), porcentagem em relação à população base $(\mathrm{DE} \%)$, contribuição dos locos homozigotos $(\mu+a)$, heterozigotos $(d)$ e relação $(\mu+a) /(d)$ para $o$ caráter número de espigas por parcela.

18 Médias dos tratamentos para os materiais $S_{o}$ e $S_{1}$, estimativas da depressão por endogamia em unidades do caráter $(\mathrm{DE})$, porcentagem em relação à população base $(\mathrm{DE} \%)$, contribuição dos locos homozigotos $(\mu+\mathrm{a})$, heterozigotos (d) e relação $(\mu+a) /(d)$ para o caráter prolificidade. 
19 Médias dos tratamentos para os materiais $S_{o}$ e $S_{1}$, estimativas da depressão por endogamia em unidades do caráter $(\mathrm{DE})$, porcentagem em relação à população base $(\mathrm{DE} \%)$, contribuição dos locos homozigotos $(\mu+\mathrm{a})$, heterozigotos (d) e relação $(\mu+a) /(d)$ para o caráter estande......

20 Médias dos tratamentos para os materiais $S_{o}$ e $S_{1}$, estimativas da depressão por endogamia em unidades do caráter $(\mathrm{DE})$, porcentagem em relação à população base (DE\%), contribuição dos locos homozigotos $(\mu+a)$, heterozigotos $(d)$ e relação $(\mu+a) /(d)$ para o caráter diâmetro da espiga (cm).

21 Médias dos tratamentos para os materiais $S_{0}$ e $S_{1}$, estimativas da depressão por endogamia em unidades do caráter $(\mathrm{DE})$, porcentagem em relação à população base $(\mathrm{DE} \%)$, contribuição dos locos homozigotos $(\mu+a)$, heterozigotos $(d)$ e relação $(\mu+a) /(d)$ para o caráter diâmetro do sabugo (cm).

22 Médias dos tratamentos para os materiais $S_{0}$ e $S_{1}$, estimativas da depressão por endogamia em unidades do caráter (DE), porcentagem em relação à população base (DE\%), contribuição dos locos homozigotos $(\mu+a)$, heterozigotos $(d)$ e relação $(\mu+a) /(d)$ para o caráter número de fileiras de grãos

23 Médias dos tratamentos para os materiais $S_{o}$ e $S_{1}$, estimativas da depressão por endogamia em unidades do caráter $(\mathrm{DE})$, porcentagem em relação à população base (DE\%), contribuição dos locos homozigotos $(\mu+a)$, heterozigotos $(d)$ e relação $(\mu+a) /(d)$ para o caráter número de grãos por fileira. 
Página

24 Médias dos tratamentos para os materiais $S_{o}$ e $S_{1}$, estimativas da depressão por endogamia em unidades do caráter (DE), porcentagem em relação à população base (DE\%), contribuição dos locos homozigotos $(\mu+a)$, heterozigotos (d) e relação $(\mu+a) /(d)$ para o caráter comprimento da espiga $(\mathrm{cm})$.

25 Médias dos tratamentos para os materiais $S_{o}$ e $S_{1}$, estimativas da depressão por endogamia em unidades do caráter (DE), porcentagem em relação à população base (DE\%), contribuição dos locos homozigotos $(\mu+a)$, heterozigotos $(d)$ e relação $(\mu+a) /(d)$ para o caráter profundidade do grão $(\mathrm{cm})$.

129

26 Valores médios dos componentes da produção de grãos para os tipos de materiais $S_{0}$ e $S_{1}$ : peso médio do grão $(\mathrm{Pg})$, em miligramas, número de espigas da parcela (NE), número de fileiras (NF), número de grãos por fileira (NGF) e produção de grãos esperada (Pesp), em miligramas por parcela.

27 Logaritmo dos valores médios da produção de grãos esperada (Pesp) e de seus componentes para os tipos de materiais $S_{0}$ e $S_{1}$.

28 Componentes da produção de grãos expressos em porcentagem com base na escala logarítmica tomando a produção de grãos esperada (Pesp) como valor $100 \%$ para os tipos de materiais $S_{0}$ e $S_{1}$

29 Diferenças dos logaritmos dos componentes da produção de grãos $\left[\log _{10}\left(S_{0}\right)-\log _{10}\left(S_{1}\right)\right]$

30 Porcentagem das diferenças dos logaritmos tomando a produção de grãos esperada como valor $100 \%$ 


\title{
DEPRESSÃO POR ENDOGAMIA DOS COMPONENTES DA PRODUÇÃO EM POPULAÇÕES E HÍBRIDOS DE MILHO (Zea mays L.)
}

\author{
Autor: RHAINER GLEICO CARDOSO \\ Orientador: Prof. Dr. CLÁUDIO LOPES DE SOUZA JÚNIOR
}

\section{RESUMO}

O objetivo deste trabalho foi avaliar a depressão por endogamia dos componentes da produção e suas contribuições na depressão por endogamia da produção de grãos em milho. Os materiais utilizados foram variedades (VAR), híbridos simples (HS), hibridos triplos (HT) e híbridos duplos (HD), com uma geração de autofecundação $\left(\mathrm{S}_{1}\right)$ e 'per se' $\left(\mathrm{S}_{0}\right)$. Esses materiais foram avaliados em faixas seguindo o delineamento em blocos completos casualizados, em três ambientes no ano agrícola de 1993/94, com dez repetições por local.

Os principais caracteres avaliados foram produção de grãos (PROD), peso de 500 grãos $\left(\mathrm{PG}_{500}\right)$, número de fileiras de grãos $(\mathrm{NF})$, número de grãos por fileira (NGF) e prolificidade (PROL). A partir das médias dos caracteres das gerações $\mathrm{S}_{0}\left(\mathrm{~m}_{\mathrm{S} 0}\right)$ e $S_{1}\left(m_{S 1}\right)$ foram obtidas as estimativas das depressões por endogamia $\left(D E=m_{S 0}-m_{S_{1}}\right)$ de cada caráter. Utilizou-se, a seguir, a metodologia de Grafius (1960) para estimar a contribuição de cada componente para a produção de grãos nas gerações $S_{0}, S_{1}$ e para a depressão por endogamia.

Todos os materiais genéticos avaliados apresentaram significativa depressão por endogamia para os caracteres avaliados, e a magnitude da depressão variou com o caráter e com o tipo de material. Em geral, os hibridos apresentaram maiores depressões por endogamia que as variedades para produção de grãos e peso de 500 grãos, mas para os demais caracteres não se observou essa tendência. Dos componentes da produção, o caráter que apresentou a menor depressão por endogamia foi o número de fileiras de grãos, seguido do número de grãos por fileira, prolificidade e peso de 500 grãos. 
O caráter peso médio do grão contribuiu com maior valor para a produção de grãos tanto em $\mathrm{S}_{0}$ quanto em $\mathrm{S}_{1}$, com valor médio de $38,0 \%$, enquanto os demais componentes contribuiram com cerca de $20,0 \%$ cada. A contribuição dos componentes da produção de grãos para a depressão por endogamia foi variável dentro de cada grupo de material avaliado. $O$ peso médio do grão foi o que mais contribuiu $(60,0 \%)$ no grupo do híbridos simples, enquanto que a prolificidade foi a que apresentou maior contribuição $(47,0 \%)$ no grupo das variedades.

Apesar de apresentar depressão por endogamia relativamente alta, o caráter prolificidade parece ser o mais indicado para ser utilizado como critério auxiliar na seleção de linhagens mais produtivas. Isso porque esse caráter é o que apresenta maior facilidade de avaliação e significativa contribuição para a produção de grãos. 


\title{
INBREEDING DEPRESSION OF YIELD COMPONENTS IN \\ POPULA TIONS AND HYBRIDS OF MAIZE (Zea mays L.)
}

\author{
Author: RHAINER GLEICO CARDOSO \\ Adviser: Prof. Dr. CLÁUDIO LOPES DE SOUZA JÚNIOR
}

\section{SUMMARY}

This research was aimed to evaluate the grain yield components and their contribution to the inbreeding depression of grain yield in maize. Materials consisted of different groups of cultivars: open-pollinated varieties (VAR), single-crosses (SC), three-way crosses (TW) and double-crosses (DC), with one generation of selffertilization $\left(\mathrm{S}_{1}\right)$ and as per se $\left(\mathrm{S}_{0}\right)$. These materials were evaluated in split-blocks following a randomized complete block design in three environments with 10 replications per environment in the agricultural season of 1993/94.

The main traits recorded were grain yield (GY), weight of 500 kernels $\left(\mathrm{W}_{500}\right)$, number of kernels per row (NKR), number of rows (NR) and prolificacy (PROL). From the means of the traits in the $\mathrm{S}_{0}\left(\mathrm{~m}_{\mathrm{s} 0}\right)$ and in the $\mathrm{S}_{1}\left(\mathrm{~m}_{\mathrm{S} 1}\right)$ generations, inbreeding depression was computed as $\mathrm{ID}=\mathrm{m}_{\mathrm{s} 0}-\mathrm{m}_{\mathrm{s}}$, for each trait. Grafius' (1960) methodology was used to compute the contribution of each component for grain yield in the generations $S_{0}$ and $S_{1}$, and for inbreeding depression.

All genetic materials presented significative inbreeding depression for the traits recorded, although the magnitude of inbreeding depression varied with the trait and with the type of material. In general, hybrids were more sensitive than varieties to inbreeding depression for grain yield and weight of 500 kernels, but for the other traits this trend was not observed. From the grain yield components, the number of rows was less sensitive to inbreeding depression followed by the number of kernels per row, prolificacy and weight of 500 kernels. 
Average kernel weight contribution to grain yield was greater than the contribution of other components for both $\mathrm{S}_{0}$ and $\mathrm{S}_{1}$ generations. Its contribution was in average $38.0 \%$ and the other components contribution was in average $20.0 \%$ each. The contribution of grain yield components to inbreeding depression varied within each group of material. For the single-crosses, the average kernel weight was the component with larger contribution $(60.0 \%)$, whereas for the varieties the prolificacy was the component whose contribution (47.0\%) for inbreeding depression was more expressive.

Despite of its high inbreeding depression, prolificacy seems to be the more suitable trait to be used as an auxiliar criterion for selecting of high yielding inbred lines during the inbred line development. This is because prolificacy could be easily evaluated and its contribution for grain yield is high. 


\section{INTRODUÇÃO}

Os efeitos da endogamia têm sido observados em várias espécies de plantas, sendo que grande parte de seu entendimento em milho foi apresentado por Shull (1908). A endogamia pode ocorrer tanto naturalmente como artificialmente, controlandose os cruzamentos entre individuos relacionados. O sistema mais comumente usado de endogamia é através de contínuas autofecundações, embora outras formas menos drásticas de endogamia também sejam empregadas. Plantas endogâmicas apresentam decréscimo no seu vigor, quando comparadas a genótipos não endogâmicos. Esse fenômeno é conhecido como depressão por endogamia, sendo que os principais caracteres agronômicos alterados são: produção, altura das plantas, ciclo vegetativo e composição química.

O sistema linhagem-híbrido de melhoramento proposto por Shull (1909), foi o esquema fundamental para produção de hibridos de milho. Contudo, a depressão por endogamia para vários caracteres importantes pode restringir a freqüência do uso de linhagens que possam ser extraidas da população. Hallauer \& Miranda Filho (1988) apresentam uma revisão dos efeitos da endogamia para vários caracteres. Muitos casos têm mostrado que o decréscimo na produção de linhagens endogâmicas pode ser tão drástica ao ponto de limitar o sucesso de se obter linhagens endogâmicas para caracteres importantes, tal como a produção. $\mathrm{O}$ método mais direto e simples para a avaliação da depressão por endogamia é a comparação entre o desempenho de linhagens $S_{1}$ (individualmente ou em bulk) e a população parental não endogâmica. 
É fato bem conhecido na literatura que o caráter produção de grãos na cultura do milho é o mais afetado pela depressão por endogamia, e tendo em vista a sua importância agronômica vem merecendo diversos estudos detalhados. Além disso, são encontrados diversos trabalhos que abordam estudos da produção de grãos através do comportamento de seus componentes sob depressão (Allard, 1960; Hallauer \& Sears, 1973; Hallauer \& Miranda Filho, 1988).

Deve-se ressaltar a importância de se estudar a contribuição dos componentes da produção envolvidos na redução da produção de grãos sob o efeito depressivo da endogamia, uma vez que o conhecimento dessa informação é fundamental para a seleção de materiais promissores quanto a extração de linhagens vigorosas. Sabendo que os efeitos individuais, que contribuem para a expressão do caráter produção de grãos, são dificeis de serem reconhecidos e avaliados separadamente, faz-se necessário o emprego de uma metodologia mais adequada para alcançar tal objetivo.

O estudo dos componentes da produção de grãos, não só em milho como também em diversas culturas, foi introduzido por Grafius (1959), que desenvolveu uma fórmula através da qual a produção de grãos é estimada como resultado do produto entre os caracteres número de espigas (NE), número de fileiras de grãos (NF), número de grãos por fileira (NGF) e peso médio do grão (Pg). Posteriormente, Grafius (1960) através da aplicação de logaritmos a esse modelo multiplicativo, tornou-o linear, o que permitiu uma avaliação mais eficaz da contribuição de cada componente para a produção. Entretanto, ainda são escassos os trabalhos referentes ao uso dessa metodologia, o que pode ser explicado em razão da dificuldade prática na medição desses caracteres citados.

Tendo em vista a importância da produção de grãos em programas de obtenção de linhagens para produção de hibridos, estudos detalhados sobre a contribuição de seus componentes da produção poderiam auxiliar na escolha de materiais potencialmente favoráveis à extração de linhagens vigorosas. 
De acordo com o exposto, o presente trabalho teve como objetivos:

a) avaliar a depressão por endogamia em diversos grupos de materiais genéticos após uma geração de autofecundação;

b) avaliar a participação dos componentes da produção de grãos sobre a produção de grãos nos diversos grupos de materiais genéticos estudados e, também, avaliar a contribuição de cada um desses componentes para a redução da produção de grãos sob o efeito da depressão por endogamia. 


\section{REVISÃO DE LITERATURA}

\subsection{Endogamia}

Por endogamia entende-se 0 acasalamento entre indivíduos aparentados, incluindo autofecundação. $\mathrm{O}$ grau de parentesco está relacionado à presença de pelo menos um ancestral comum em alguma geração anterior. Se todos os indivíduos de uma geração qualquer possuíssem ancestrais separados, o número destes ultrapassaria os limites de uma população real. Portanto, qualquer par de indivíduos deve estar relacionado com um ou mais ancestrais comuns num passado mais ou menos remoto, e quanto menor o tamanho da população em gerações anteriores, maior a probabilidade de ocorrência de ancestrais comuns (Falconer, 1989).

A principal conseqüência resultante do fato de dois indivíduos possuírem um ancestral comum é que eles podem carregar réplicas de um dos alelos presentes no ancestral, e se eles se acasalam, podem transmitir essa réplicas à sua progênie. Portanto, indivíduos endogâmicos podem carregar, em um loco, dois alelos que são réplicas de um mesmo alelo de alguma geração anterior.

A endogamia pode ser medida através do coeficiente de endogamia, que se refere à probabilidade de dois alelos tomados ao acaso em qualquer loco, num indivíduo, serem idênticos por descendência. Reflete assim, o grau de parentesco entre os genitores desse indivíduo. $\mathrm{O}$ coeficiente de endogamia, geralmente expresso por $\mathrm{F}$, foi primeiramente definido por Wright (1922), como sendo a correlação entre os gametas que se unem. Posteriormente, Malecot (1948) e Crow (1954) propuseram a definição aqui apresentada, que é equivalente. 
Deve-se ressaltar que este conceito somente é válido quando existe especificação de algum ponto no passado, no qual todos os alelos presentes na população são considerados independentes, ou seja, não idênticos por descendência. Este ponto representa a população base, e, por definição, tem um coeficiente de endogamia igual a zero. Em determinada geração subseqüente, o coeficiente de endogamia expressa a magnitude total do processo dispersivo que vem ocorrendo, desde a população base (Rezende, 1997).

Em programas de melhoramento de plantas a existência de variabilidade genética é uma exigência básica na obtenção de genótipos superiores. Essa variabilidade pode ser gerada mediante introgressão genética e mutações e, em populações com alto grau de melhoramento, variabilidade adicional pode ser liberada através de processos endogâmicos. A endogamia, além de liberar variabilidade genética, pode ser utilizada para diminuir a carga genética, identificar progenitores potenciais, identificar fontes para derivar linhagens e/ou para determinar a importância dos efeitos epistáticos na expressão de um caráter (Blandón, 1996).

Diversos procedimentos podem ser utilizados para produzir endogamia, sendo que os mais comuns envolvem cruzamentos entre parentes como irmãos completos, meios irmãos e autofecundação. Uma das maiores aplicações da endogamia está relacionada à obtenção de linhagens homozigóticas requeridas na produção híbridos. A autofecundação, devido a sua rapidez para atingir a homozigosidade total, é o procedimento mais utilizado neste propósito; no entanto, apresenta como desvantagem baixa eficiência na produção de linhagens. Uma alta proporção destas, são descartadas já nas primeiras gerações de autofecundação em vista da falta de adaptação decorrente da fixação de alelos prejudiciais (Blandón, 1996).

A grande importância da endogamia está no desenvolvimento de genótipos que podem ser perpetuados através de múltiplas gerações de produção de sementes com mínimas modificações na sua composição genética, sendo empregada no melhoramento genético tanto para a produção de híbridos de linhagens endogâmicas, quanto para o melhoramento de populações. 
Deve-se lembrar que a endogamia não está associada à efeitos biológicos desfavoráveis como, por exemplo, perda de vigor, alterações metabólicas ou anomalias. A endogamia apenas expõe genes deletérios ou letais (mascarados pelo alelo dominante nos heterozigotos) em dupla dose. Quando uma população com elevada concentração de tais genes (carga genética) é submetida a autofecundação, a depressão por endogamia é muito alta. Por esse motivo, em populações de milho, por exemplo, das quais se deseja obter linhagens endogâmicas, geralmente são realizadas autofecundações periódicas para retirada ou diminuição da quantidades desses genes. Nas espécies autógamas não existe carga genética, pois ela foi eliminada durante o processo de evolução.

\subsection{Depressão por endogamia: Base Genética}

Como comentado anteriormente, o acasalamento entre indivíduos aparentados provoca aumento da homozigose e decréscimo de heterozigose na descendência. Isso permite que alelos recessivos de efeito desfavorável, encobertos pelos respectivos dominantes na antiga condição de heterozigose, se manifestem em homozigose, causando a chamada depressão por endogamia, que resulta numa redução no valor adaptativo do individuo. A quantidade total desses alelos desfavoráveis é chamada de carga genética. Portanto, quanto maior a carga genética, maior a depressão por endogamia (Vencovsky \& Barriga, 1992). Deve-se mencionar, contudo, que a redução na heterozigose, por si só, também leva a depressão por endogamia, em função da perda de interações alélicas favoráveis (dominância e/ou sobredominância), independentemente da presença de carga genética (Hallauer \& Miranda Filho, 1988; Souza Júnior \& Fernandes, 1997).

A depressão por endogamia é observada através da redução do valor fenotípico expressa pelos caracteres relacionados com a capacidade reprodutiva ou eficiência fisiológica (Falconer, 1989). Na prática, ela é observada pela redução na 
produção de sementes, na fertilidade do pólen, na taxa de crescimento, no tamanho e vigor das plantas, na maior suscetibilidade à pragas e doenças, além de outros eventos depressivos em diversos caracteres (Allard, 1960; Hallauer \& Miranda Filho, 1988), sendo que sua intensidade varia de acordo com a população. Também espera-se que a mesma varie dentro das populações, isto é, que genótipos de uma população tenham diferentes valores fenotípicos médios sob endogamia.

Apesar da importância da depressão por endogamia, as causas genéticas deste fenômeno não são completamente conhecidas, existindo algumas hipóteses para explicá-la. Como comentado anteriormente, a depressão por endogamia é resultante da quebra da combinação ideal dos alelos que governam um caráter (efeito de dominância e/ou sobredominância) e também do aparecimento em dupla dose de alelos recessivos deletérios e/ou letais, no caso de espécies diplóides.

Uma das teorias que explicam o fenômeno é a da dominância parcial, a qual afirma que a existência de dominância entre alelos faz com que hajam diferenças entre valores genotípicos de homozigotos e heterozigotos. Dessa forma, a simples endogamia sem seleção faz com que haja alterações na média da população, sendo que a diminuição da média considerando o efeito combinado de todos os locos que influenciam um caráter qualquer é de: $-2 F \sum_{i} p_{i} q_{i} d_{i}$ (Falconer, 1989), sendo $p_{i}$ e $q_{i}$ as frequiências gênicas no loco $i, d_{i}$ o valor genotípico codificado do heterozigoto para o loco i e F o coeficiente de endogamia. $\mathrm{O}$ valor de $\mathrm{d}_{\mathrm{i}}$ será zero na ausência de dominância, mas aumenta à medida que aumenta o grau médio de dominância. A depressão causada pela endogamia é, então, proporcional ao grau de dominância, sendo maior para os locos com freqüências intermediárias. Uma vez que os caracteres quantitativos estão sob controle de muitos locos, a redução do caráter dependerá do grau médio de dominância (Allard, 1960; Williams, 1964; Falconer, 1989). Uma vez que os caracteres em uma mesma planta ou espécie apresentam diferentes níveis de dominância média é de se esperar que apresentem diferentes respostas a depressão por endogamia em função do grau de dominância. Para os caracteres em que o grau de dominância média é alto, como por exemplo para a produção de grãos e o peso de espigas despalhadas a depressão é muito 
drástica, reduzindo muito o valor da média desses caracteres após uma geração de autofecundação. Por outro lado, para caracteres em que o grau médio de dominância é menor, como por exemplo para a altura da planta e a altura da espiga, a depressão verificada é menor. Além disso, a depressão por endogamia é diretamente proporcional ao coeficiente de endogamia (F). Falconer (1989) relata que quanto maior o grau de parentesco entre os dois indivíduos que se acasalam (maior valor de F), maior será a depressão por endogamia esperada.

Diversos estudos têm mostrado que a endogamia causa mudança na média fenotípica em uma direção que causa redução no seu valor (Charlesworth \& Charlesworth, 1987; Ralls et al., 1988; Lynch, 1989).

Outra teoria é a da carga genética, que explica que a endogamia expõe genes recessivos deletérios e/ou letais em dupla dose, o que causa a perda de vigor da planta e de populações. Willis (1992) afirma que a carga genética só é mantida na população graças a vantagem adaptativa dos heterozigotos sobre os homozigotos para os alelos favoráveis, o que faz com que alelos recessivos indesejáveis sejam, muitas vezes, mantidos na população. Os genes recessivos mais comuns relacionados com a queda do vigor são os de deficiência de clorofila (Willis, 1992).

Dessas duas teorias citadas a da dominância genética é tida como o principal responsável pela depressão por endogamia (Crow, 1948; Lande \& Schemske, 1985; Charlesworth \& Charlesworth, 1987). Entretanto, a validade dessas duas teorias é de dificil verificação porque há um grande número de genes envolvidos, com pequeno efeito individual. Cabe ressaltar que tais hipóteses simplificam muito a explicação desse fenômeno, e não são excludentes, somando-se. Apesar de muitos autores defenderem uma ou outra dessas hipóteses, na verdade a depressão por endogamia deve ser resultante do aglomerado de todos os efeitos explicados por essas.

Hallauer \& Miranda Filho (1988) afirmam que o desempenho médio para um determinado caráter é relacionado linearmente com seu nível de heterozigosidade, enquanto o desvio da linearidade é atribuído a interações interalélicas ou epistasia. Estudos da endogamia através de regressão têm revelado que a produção de 
grãos em milho pode ser descrita adequadamente por um modelo genético aditivo dominante. Foi observado pelos referidos autores que mais de $90 \%$ da variação na queda do vigor foi explicada pelo coeficiente de endogamia. A mesma situação foi observada para os caracteres altura da planta, comprimento da espiga, diâmetro da espiga, número de fileiras de grãos por espiga e peso de grãos em milho (Hallauer \& Sears, 1973; Cornelius \& Dudley, 1974; Good \& Hallauer, 1977; Benson \& Hallauer, 1994).

Segundo Stebbins (1957), a perda de vigor resultante da autofecundação em plantas de polinização cruzada é mais acentuada nas primeiras gerações e torna-se progressivamente menor nas gerações subseqüentes. Esta redução do vigor é devido aos genes recessivos de efeitos desfavoráveis presentes no conjunto gênico de uma determinada população e que estão mascarados pelos alelos dominantes em locos heterozigóticos.

Do exposto acima, observa-se que para Hallauer \& Miranda Filho (1988) a depressão por endogamia se deve principalmente ao nível de heterozigosidade do material e que apresenta decréscimo linear ao longo de sucessivas autofecundações, por outro lado Stebbins (1957) defende a idéia de que depressão por endogamia é explicada principalmente pela carga genética presente no material e que seu decréscimo não é linear. Deve-se observar aqui que Hallauer \& Miranda Filho (1988) estudaram principalmente materiais híbridos provenientes de linhagens endogâmicas, e portanto, apresentam quase nenhuma carga genética, além disso apresentam alto nivel de heterozigose, o que permite concluir que a depressão nesse tipo de material é devida exclusivamente a segregação de alelos devida a endogamia. Por outro lado, Stebbins (1957) estudou as mais variadas espécies de plantas, nas quais esse autor se preocupou em estudar a perda de vigor através da expressão de genes deletérios e/ou sub-letais.

A depressão por endogamia total (D.E.) é medida pela diferença entre $S_{\mathrm{o}}$ e $S_{e}$, onde $S_{o}$ é a média da população original e $S_{e}$ a média da população endogâmica. Portanto, a estimativa da depressão por endogamia é dada por: D.E. $=S_{e}-S_{o}$ $=-2 F \sum_{i} p_{i} q_{i} d_{i}$. Também, costuma-se estimar a depressão por endogamia em termos de 
porcentagem em relação à média da população original; assim, tem-se: D.E. $(\%)=$ $\left[\left(\mathrm{S}_{\mathrm{e}}-\mathrm{S}_{\mathrm{o}}\right) / \mathrm{S}_{\mathrm{o}}\right] .100$.

O efeito da endogamia sobre a variância genética de um caráter métrico é aparente pela descrição das mudanças das freqüências gênicas. Considerando-se uma população constituída de diferentes genes em seus locos, o efeito da endogamia será dispersivo, de modo que a tendência é de se formarem diversas linhas de indivíduos homozigóticos, diferenciados pela freqüência gênica. Uma vez que o valor genotípico médio de um caráter quantitativo depende das freqüências gênicas nos locos que a afetam, as linhas tornam-se diferenciadas em relação ao seu valor genotípico médio. E, uma vez que os componentes genéticos da variância se reduzem à medida que as freqüências gênicas tendem a direção dos valores extremos 0 ou 1 , a variância genética dentro das linhas decresce. A conseqüência geral da endogamia, portanto, é uma redistribuição da variância genética; o componente que surge entre as médias de linhas aumenta, enquanto aquele que aparece dentro das linhas diminui. Portanto, o que a endogamia faz é promover diferenciação genética entre linhas e uniformidade genética dentro delas (Falconer, 1989).

Souza Júnior \& Fernandes (1997) a partir da simulação de dados verificaram a possibilidade de derivar a variância genética, permitindo predizer a amplitude da depressão por endogamia em gerações avançadas para populações panmíticas. Segundo os autores a variância da depressão é função das variâncias genéticas relacionadas ao efeito de dominância e dos coeficientes de endogamia das gerações avaliadas. Concluiu-se que, quanto maior o nível de dominância de um determinado caráter, maior é a variância da depressão, e que as amplitudes de tais variâncias são menores em populações com $\mathrm{p}>0,6$ ou $\mathrm{p}<0,4$ do que em populações com $\mathrm{p}=0,5$. 


\subsection{Depressão por endogamia em milho}

A prática da autofecundação é largamente utilizada em processos de melhoramento de milho, tanto na obtenção de linhagens para produção de híbridos, como na avaliação de progênies $S_{1}$ ou $S_{2}$ no melhoramento de populações. Hallauer \& Sears (1973) comentam que, embora os efeitos da endogamia sejam conhecidos desde o início do século, poucas avaliações foram feitas no sentido de quantificar as alterações em caracteres quantitativos associados com a endogamia.

Os primeiros experimentos com autofecundação em milho foram conduzidos por Darwin (1877), onde foram observadas reduções no vigor das plantas. Posteriormente McCluer '1(1892), citado por Pinho (1995), informou a respeito da obtenção de híbridos enfatizando que o cruzamento aumentava o vigor e o rendimento, e que a autofecundação produzia plantas parcialmente estéreis; observou ainda, que a segunda geração de sementes híbridas apresentava rendimento mais baixo que a primeira. Entretanto, foi Shull (1909) quem começou os trabalhos com autofecundação em milho visando a produção de milho híbrido, indicando a superioridade do cruzamento entre linhagens autofecundadas. O nível de redução, com a endogamia, variou com os genótipos envolvidos.

O fenômeno da depressão por endogamia em milho tem merecido muitos estudos, principalmente para o caráter produção de grãos. Conforme mencionado por Hallauer \& Miranda Filho (1988), este assunto já foi objeto de consideração de East \& Jones (1918) e Jones (1918).

Hallauer \& Miranda Filho (1988) reportaram estimativas de depressão por endogamia em populações de milho para vários caracteres. Observaram que existe uma grande variação deste fenômeno de caráter para caráter, e que o caráter produção de grãos é o que sofre maior depressão. Esta última observação também foi relatada por Jones (1918), Hallauer \& Sears (1973), Good \& Hallauer (1977) e Marques (1988).

\footnotetext{
${ }^{1}$ McCluer, G.W. Corn crossing III. Agr. Exp. Sta., 1892. n.p. (Bulletin 12)
} 
Hallauer \& Miranda Filho (1988) reportaram ainda que diferentes populações exibem diferentes níveis de depressão por endogamia para um mesmo caráter. Deve-se ressaltar aqui, que a depressão para produtividade de grãos e outros caracteres quantitativos, pode levar a uma situação na qual o decréscimo na produtividade em linhagens endogâmicas se toma tão acentuado a ponto de limitar sua utilização em programas de obtenção de híbridos. Evidentemente, isso depende do nível de melhoramento que a população apresenta.

Em trabalhos realizados por Hallauer \& Sears (1973), verificou-se que o número de locos que afetam um determinado caráter é um fator determinante na relação entre a taxa de declínio observado com o aumento da homozigose. Isto significa que em caracteres expressos por menor número de genes, a homozigose é atingida mais rapidamente em comparação a um caráter mais complexo, onde participa um grande número de genes, como é o caso da produção de grãos.

Conforme relatam Hallauer \& Miranda Filho (1988), embora um grande número de autofecundações já tenham sido realizadas na cultura do milho, as estimativas de depressão por endogamia para diferentes caracteres é surpreendentemente pequena na maioria dos casos. Em levantamento realizado pelos autores, a depressão por endogamia esperada para produção de grãos, ao nível de 50\% de homozigose induzida pela autofecundação, variou de 42,2 a 71,9 gramas/planta, enquanto que para a altura da planta e a altura da espiga, os valores oscilaram entre 7,8 a 33,4 cm e 10,4 a 29,6 cm, respectivamente.

Estimativas de depressão por endogamia expressas pela diferença entre as médias das gerações $S_{o}$ e $S_{e}$ em relação à $S_{o}$, foram obtidas por diversos autores, para vários caracteres, em variedades ou compostos (Sing et al. 1967; Paterniani, 1980; Geraldi \& Vencovsky, 1980; Vianna et al., 1982; Lima et al., 1984; Gama et al., 1985; Nass \& Miranda Filho, 1995); variedades sintéticas (Genter, 1971; Meghji et al., 1984; Lamkey \& Smith, 1987), híbridos simples e duplos (Gama \& Hallauer, 1977; Gama et al., 1985) e híbridos triplos (Gama et al., 1985). Os valores de depressão por endogamia variaram entre zero e 58,0\%, para a produção de grãos; entre 9,6 e 20,3\%, para a altura 
da planta; entre 3,9 e 27,4\%, para a altura da espiga; entre 5,1\% e 12,6\%, para o comprimento da espiga; entre 2,2 e $8,9 \%$, para o diâmetro da espiga; entre 0,6 e 5,2\%, para o número de fileiras de grãos por espiga e entre 3,9 e $14,75 \%$, para o peso de 300 sementes.

Jones (1939) relatou decréscimos na produção da ordem de 79\% após 30 gerações de autofecundação, com valores crescentes de depressão por endogamia até a vigésima geração. As médias de altura da planta, no entanto, foram reduzidas em $29 \%$, estabilizando-se por volta da $5^{\underline{a}}$ geração de autofecundação. Tendências semelhantes foram encontradas por Hallauer \& Sears (1973) e Good \& Hallauer (1977), submetendo a população "Iowa Stiff Stalk Synthetic" (BSSS) a sucessivas gerações de autofecundação. Tais resultados são atribuidos aos maiores níveis de dominância gênica, aliados a alta complexidade do caráter produção de grãos.

Mota (1974) estudando a variedade Centralmex comparou linhagens endogâmicas $S_{1}$ com progênies que eram meias irmãs de $S_{1}$ 's. Verificou que os caracteres peso de espigas, peso de grãos e peso de 100 grãos apresentaram valores de depressão por endogamia de $34,27 \%, 36,68 \%$ e $34,27 \%$, respectivamente, sendo estes, dentre os caracteres estudados, os mais afetados. Os caracteres número de grãos por fileira e altura da planta, apresentaram uma porcentagem de depressão intermediária, aproximadamente 15,41\%. A altura da espiga, comprimento e diâmetro da espiga manifestaram uma perda em torno de $9,32 \%$. O caráter que apresentou menor porcentagem de depressão foi número de fileiras de grãos, com valor de depressão próximo de 3,65\%.

Lamkey \& Smith (1987) avaliaram a depressão por endogamia em sintéticos representando sete décadas de melhoramento (antes de 1930 e as seis décadas subseqüentes). A melhoria no desempenho das populações $S_{0}$ e $S_{1}$, bem como os aumentos na diferença $\left(S_{0}-S_{1}\right)$ com o decorrer das décadas foram atribuidos a dois fatores: a) maior número de locos em heterozigose das populações; b) baixos valores de freqüências de alelos favoráveis $(\mathrm{p}<0,5)$ nas populações originais, sendo aumentadas nas populações recentes. 
No Brasil vários estudos têm sido conduzidos para avaliar a depressão por endogamia já que as populações atualmente disponíveis apresentam uma acentuada carga genética (Marques, 1988). Estimativas de depressão por endogamia após uma geração de autofecundação, expressas em porcentagem em relação à $S_{o}$ são observadas por diversos autores. Geraldi \& Vencovsky (1980) apresentaram valores de depressão por endogamia para o caráter produção de nove populações brasileiras variando entre 36,7 \% a $54,8 \%$. Para a produção de grãos de 14 populações introduzidas, Vianna et al.(1982) constataram valores para esse fenômeno variando de 42,0 \% a 58,0 \%. Valois \& Miranda Filho (1984) avaliando a produção de grãos da variedade Centralmex encontraram uma depressão por endogamia da ordem de $39,0 \%$.

Extensas avaliações foram realizadas em 32 populações de milho brasileiras por Lima et al. (1984), tendo observado que a depressão por endogamia, após uma geração de autofecundação, variou de $27,0 \%$ a $59,9 \%$ para a produção de grãos; de $6,6 \%$ a $20,3 \%$ para a altura da planta e, de $6,9 \%$ a $27,4 \%$ para a altura da espiga. Verificaram também que para o caráter produção de grãos as populações derivadas de linhagens endogâmicas apresentaram valor médio de $34,0 \%$ de depressão, enquanto que nos compostos e variedades de polinização livre, a média foi de $41,3 \%$. De acordo com Miranda Filho \& Viegas (1987) tais resultados corroboram em certo grau com a hipótese de que populações derivadas de linhas endogâmicas, ou que já passaram por alguma fase de endogamia, são menos sensiveis aos efeitos de depressão causados por genes deletérios.

Medidas de depressão por endogamia após uma geração de autofecundação em populações semi-exóticas de milho EE1 (ESALQ-PB1 x Entrelaçado 1) e EC4 (ESALQ PBl x Cravo 4) são apresentadas por Nass (1992), sendo respectivamente, $13,7 \%$ e $12,8 \%$ para altura da planta; $15,9 \%$ e $14,2 \%$ para altura da espiga; $45,9 \%$ e $31,3 \%$ para número de espigas; $17,14 \%$ e $12,39 \%$ para diâmetro da espiga; $19,1 \%$ e $9,8 \%$ para estande; $44,8 \%$ e $44,9 \%$ para peso de espigas e $44,8 \%$ e $46,7 \%$ para peso de grãos. 
Terasawa Júnior (1993) avaliou material $S_{1}$ no quarto ciclo de seleção recorrente com endogamia nas populações de milho ESALQ PB2- $\mathrm{C}_{3}$ e ESALQ PB3$\mathrm{C}_{3}$, com ênfase na determinação da depressão por endogamia. Para as populações-base ESALQ PB2- $C_{3}$ e ESALQ PB3- $C_{3}$ a depressão estimada foi de $40,0 \%$ e $44,0 \%$ para produção de grãos; $8,1 \%$ e $8,0 \%$ para altura da planta e $8,9 \%$ e $8,2 \%$ para altura da espiga, respectivamente.

Na Tabela 1 adaptada de Vencovsky et al.(1988) e de Terasawa Júnior (1993), encontram-se outras estimativas de depressão por endogamia em diferentes materiais genéticos. De acordo com essas estimativas, nota-se que as variedades de polinização livre e as populações, exibiram praticamente tanta depressão quanto à observada pelo grupo de híbridos.

Silva e Pinto (1982) avaliando a depressão por endogamia em seis variedades de milho opaco-2, a saber, Centralmex, Composto Flint, Composto Dent, AG 504, UFV e Colômbia endosperma duro, encontraram valores depressivos de $16,2 \%$, $15,6 \%, 14,3 \%, 51,7 \%$ e $55,4 \%$ para os caracteres altura da planta, altura da espiga, peso de 500 grãos, peso de espigas (t/ha) e produção de grãos ( $t / h a)$, respectivamente. Os autores observaram ainda que nas comparações dos referidos caracteres, notou-se que a depressão foi menor nos que foram mais intensamente submetidos à seleção.

Estudos de Gama et al. (1985) sobre o efeito da depressão por endogamia após uma geração de autofecundação em materiais de híbridos simples, triplos, duplos e intervarietais, encontraram para altura da planta valores médios de depressão por endogamia de 4,53\%,7,50\%, 8,32\% e 7,09\% para esses grupos, respectivamente. Para o caráter altura da espiga encontraram valores de 5,06\%, 8,74\%, $8,85 \%$ e $8,61 \%$, respectivamente. Para o caráter prolificidade os valores de $6,30 \%$, $1,37 \%, 2,23 \%$ e $9,16 \%$, respectivamente. Já para produção de grãos verificaram uma redução média da ordem de $34,28 \%$ para híbridos simples, $26,49 \%$ para híbridos triplos, $32,35 \%$ para híbridos duplos e $26,98 \%$ para os hibridos intervarietais. 
Tabela 1. Estimativas da depressão por endogamia (\%), em relação às médias $S_{0}$, para peso de grãos, em diferentes materiais genéticos do Brasil.

\begin{tabular}{|c|c|c|}
\hline Material Genético & Média \% & Intervalo de Variação (\%) \\
\hline Várias Populações $\left(\mathrm{S}_{0}, \mathrm{~S}_{1}\right)$ & 45,8 & 40,2 a $60,4(1)$ \\
\hline Várias Populações $\left(\mathrm{S}_{0}, \mathrm{~S}_{1}\right)$ & 40,5 & 27,0 a $57,9(2)$ \\
\hline Vários Hibridos $\left(\mathrm{S}_{0}, \mathrm{~S}_{1}\right)$ & 48,6 & 40,9 a $56,7(3)$ \\
\hline \multicolumn{3}{|l|}{ Variedades } \\
\hline CMS-05-C $\left(\mathrm{S}_{0}, \mathrm{~S}_{1}\right)$ & 42,5 & 18,6 a $66,0(4)$ \\
\hline CMS-05-C $1\left(\mathrm{~S}_{0}, \mathrm{~S}_{1}\right)$ & 38,9 & 17,9 a $58,4(4)$ \\
\hline Centralmex $\left(\mathrm{S}_{0}, \mathrm{~S}_{1}\right)$ & 36,7 & 11,6 a $67,4(5)$ \\
\hline \multicolumn{3}{|l|}{ Compostos } \\
\hline ESALQ $-\mathrm{PB} 2-\mathrm{C}_{2}\left(\mathrm{~S}_{0}, \mathrm{~S}_{1}\right)$ & 43,7 & 15,2 a $76,3(6)$ \\
\hline ESALQ - PB3 $-C_{2}\left(S_{0}, S_{1}\right)$ & 49,4 & 22,5 a $76,1(6)$ \\
\hline ESALQ $-\mathrm{PB} 2-\mathrm{C}_{3}\left(\mathrm{~S}_{0}, \mathrm{~S}_{1}\right)$ & 40,0 & 1,5 a $65,8(7)$ \\
\hline ESALQ $-\mathrm{PB} 3-\mathrm{C}_{3}\left(\mathrm{~S}_{0}, \mathrm{~S}_{1}\right)$ & 44,0 & 12,4 a $69,1(7)$ \\
\hline Suwan - DMR $\left(S_{0}, S_{1}\right)$ & 42,4 & $--\quad(8)$ \\
\hline Composto Thai $\left(\mathrm{S}_{0}, \mathrm{~S}_{1}\right)$ & 42,3 & $--\quad(8)$ \\
\hline $\mathrm{EE} 1\left(\mathrm{~S}_{0}, \mathrm{~S}_{1}\right)$ & 46,2 & 30,2 a $91,4(9)$ \\
\hline $\mathrm{EC} 4\left(\mathrm{~S}_{0}, \mathrm{~S}_{1}\right)$ & 46,7 & 9,4 a 81,7 \\
\hline
\end{tabular}

(1) Vianna et al.(1982); (2) Lima et al.(1984); (3) Gama et al.(1985); (4) Môro (1982); (5) Mota (1974); (6) Marques (1988); (7) Terasawa Júnior (1993); (8) Lima et al. (1982); (9) Nass \& Miranda Filho (1995). 
Mauro (1990) avaliando um material Composto Dentado encontrou valores depressivos na primeira geração de autofecundação de 19,20\% para a altura da planta, $24,86 \%$ para altura da espiga, $32,60 \%$ para peso de espigas e $35,21 \%$ para peso de grãos.

Hallauer \& Sears (1973) avaliando a depressão por endogamia em sucessivas gerações de autofecundação na variedade sintética "Iowa Stiff Stalk Synthetic" (BSSS) para diversos caracteres da planta e da espiga, encontram para a primeira geração de autofecundação, reduções de 12,75\% para altura da planta, 16,84\% para altura da espiga, 8,67\% para comprimento da espiga, 8,13\% para diâmetro da espiga, 3,69\% para diâmetro do sabugo, 12,95\% para comprimento do grão, 4,67\% para largura da espiga com palha e $31,28 \%$ para produção de grãos (Kg/ha).

Outros trabalhos de avaliação da depressão por endogamia confirmam a importância de seu estudo em diversos materiais genéticos de milho, especialmente após uma geração de autofecundação. Morera (1989) examinando os efeitos da depressão por endogamia em variedades sintéticas encontrou valores de 30,23\% a 36,17\% para produção de grãos. Eagles \& Hardacre (1993) observaram a depressão por endogamia variando de 48,2\% a 65,3\% em cinco variedades sintéticas para o caráter produção de grãos. Esses autores relataram que a elevada depressão por endogamia apresentada por algumas das variedades foi devida a presença de genes deletérios recessivos.

Um aspecto importante da depressão por endogamia é que esta sofre alterações na medida em que se melhora as populações. Genter (1971), Burton et al.(1971), Harris et al.(1972), Goulas \& Lonquist (1976) e Benson \& Hallauer (1994) relataram que o melhoramento nas populações implicam em um decréscimo na depressão, uma vez que os genes deletérios e/ou letais são eliminados. Walters et al.(1991) realizaram avaliações da depressão por endogamia na variedade sintética "Towa Staff Stalk Synthetic" e em populações dessa variedade melhoradas através de sete e nove ciclos de seleção recorrente. Esses autores verificaram que para todos os caracteres avaliados a depressão por endogamia diminuiu significativamente. Para o caráter produção de grãos a depressão por endogamia na população original era de $34,47 \%$ e foi 
reduzida para $18,20 \%$ a $23,17 \%$ nas populações melhoradas. Para os caracteres da planta número de espigas por planta, altura da planta e altura da espiga, a depressão por endogamia na população original era de $11,11 \%, 9,76 \%$ e $12,02 \%$, respectivamente, e foram reduzidas para $0,00 \%$ a $10,00 \%, 8,13 \%$ a $8,37 \%$ e $10,30 \%$ a $13,07 \%$, respectivamente. Para os caracteres da espiga comprimento da espiga, diâmetro da espiga, número de fileiras e peso de 300 grãos, a depressão por endogamia na população original era de $18,04 \%, 6,81 \%, 4,10 \%$ e $7,69 \%$, respectivamente, e foram reduzidas para $7,23 \%$ a $10,96 \%, 2,38 \%$ a $4,65 \%, 0,00 \%$ a $2,90 \%, 2,48 \%$ a $5,63 \%$, respectivamente. $\mathrm{O}$ caráter comprimento do grão, que não apresentava depressão por endogamia na população original manteve esse mesmo comportamento nas populações melhoradas.

Por outro lado, no melhoramento de materiais híbridos, Lamkey \& Smith (1987), verificaram que na avaliação de sintéticos representativos de sete eras de melhoramento houve um aumento na depressão à medida que os híbridos são melhorados. Com isso, mostraram que o melhoramento está incrementando o nível de heterozigose dos híbridos. A taxa de ganho genético para produtividade foi de 0,38 ton/ha para a população $S_{1}$, sendo esta significativamente menor que a taxa de ganho genético para a população $S_{0}$. Além disso, a depressão como porcentagem de $S_{0}$ não mostrou diferença entre as eras. Notou-se também, que a sua taxa na era 6 , apresentavase como o dobro das populações de polinização livre.

Cabe aqui ressaltar o fato de que enquanto as populações tendem a ter a depressão por endogamia reduzida à medida que são melhoradas, com os híbridos ocorre o contrário, a sua depressão aumenta, sendo as explicações desses fatos totalmente distintas. No caso das populações a diminuição da depressão por endogamia ocorre em razão de o melhorista eliminar as plantas com baixo vigor durante o processo de melhoramento, o que significa eliminação de genes deletérios e/ou letais. Com isso, no final do processo de melhoramento essa população se encontra com baixo nível de genes desfavoráveis, os quais já se sabe, são responsáveis pela depressão por endogamia. No caso dos híbridos, para os quais o processo de melhoramento se dá pela exploração da heterose, o aumento da depressão por endogamia se deve ao fato de haver aumento do 
nível de heterozigose, especialmente os híbridos simples, onde o nível é muito elevado. Sendo assim, nos híbridos os efeitos de dominância e/ou sobredominância são muito grandes para diversos caracteres. Portanto, a ocorrência de endogamia nos híbridos levaria a uma quebra da combinação gênica ideal e, assim, reduziria o valor fenotípico médio para esses diversos caracteres.

Para o caráter produção de grãos, tem sido observada, de maneira geral, uma tendência de redução da depressão por endogamia dos materiais submetidos a diferentes métodos de seleção recorrente (Genter, 1971; Goulas \& Lonquist, 1976; Oyervides-Garcia \& Hallauer, 1986; Hallauer et al., 1988; Rodriguez \& Hallauer, 1988; Odhiambo \& Compton, 1989).

No melhoramento via seleção recorrente para que os objetivos possam ser alcançados, deve-se trabalhar com tamanhos efetivos populacionais suficientemente grandes (Pereira \& Vencovsky, 1988), o que muitas vezes não acontece em função das fortes intensidades de seleção aplicadas durante as gerações de melhoramento. Como conseqüência disso, deve ocorrer depressão por endogamia (Rezende, 1997).

Estudos teóricos realizados por Souza Júnior (1985), para seleção recorrente intrapopulacional, mostram que, considerando um loco com dois alelos e dominância completa, a depressão por endogamia só diminui quando a freqüência do alelo favorável é superior a 0,5 . Se essa freqüência for inferior a 0,5 , a depressão por endogamia tende a se acentuar com a seleção. Portanto, este modelo explica os resultados citados na literatura, uma vez que espera-se um aumento na frequência dos alelos favoráveis para um grande número de locos, na medida em que se pratica o melhoramento das populações.

Fernandes (1990) demonstrou que a alteração ocorrida na depressão por endogamia, após a realização de um ciclo seletivo, é função da diferença entre o progresso esperado na população sob seleção e o progresso esperado nas linhagens dela originadas, obtendo, para vários esquemas de seleção recorrente, expressões que possibilitaram a comparação entre os métodos. De maneira geral, concluiu-se que tanto para a seleção intra como para a interpopulacional, a depressão por endogamia aumenta 
em populações com baixas freqüências de alelos favoráveis $(<0,5)$, praticamente não se altera em populações com freqüências altas de alelos favoráveis $(>0,5)$, confirmando exatamente os mesmo padrões observados por Souza Júnior (1985). Foi evidenciado ainda, que dentro desta tendência geral esperada, os diferentes esquemas de seleção recorrente podem alterar a depressão por endogamia em diferentes intensidades.

Variações na depressão por endogamia devidas à seleção foram reportadas por Odhiambo \& Compton (1989). Para as populações NBS, NSS e NKS, a depressão por endogamia para o caráter produção de grãos caiu de $33,2 \%$ para $22,0 \%$, de $37,5 \%$ para $20,6 \%$ e de $35,1 \%$ para $14,9 \%$, respectivamente, após cinco ciclos de seleção com progênies $S_{1}$ 's.

Oyervides-Garcia \& Hallauer (1986) reportam alterações na depressão por endogamia na população BSSS para o caráter produção de grãos na seleção. A depressão por endogamia na primeira geração de autofecundação para a população original (BSSSCO) que era de $41,5 \%$, alterou-se para $35,8 \%$ após 3 ciclos com materiais $S_{1}$ 's e $40,5 \%$ após 2 ciclos com materiais $S_{2}$ 's.

Hallauer et al. (1988) reportam alterações na depressão por endogamia para seis caracteres em milho na população BSK. Após 4 e 8 ciclos de seleção com progênies endogâmicas $S_{1}$ 's, a depressão por endogamia alterou de $43,1 \%$ na população original para $37,2 \%$ e para $31,3 \%$, respectivamente para o caráter produção de grãos.

Das comparações entre as populações melhoradas e suas respectivas populações originais, desconsiderando os métodos de melhoramento, foi evidente que as primeiras, na maioria dos casos, manifestaram menor depressão. Dessa maneira, a depressão por endogamia deixou transparecer que nas populações melhoradas houve maior freqüência de alelos favoráveis, menor número de locos segregantes ou frequiências gênicas acima de 0,5 .

Outro ponto a ser lembrado é que a homozigose não é um estado genético natural de espécies em que predomina o intercruzamento das plantas, ou seja, a alogamia. Daí a dificuldade de obter-se linhagens puras vigorosas e sadias. Linhagens com tais propriedades, todavia, são condições básicas para viabilizar o programa de 
produção de híbridos. Para que se possa obtê-las com uma probabilidade aceitável, devese partir de populações geneticamente adequadas, o que significa que tais populações devem ter alta freqüência de alelos favoráveis para diversos caracteres de interesse e baixa frequêencia de alelos desfavoráveis (carga genética). A primeira condição, atingível pela seleção recorrente, é sinônima de alta capacidade geral de combinação. A segunda, por sua vez, significa baixa depressão por endogamia (Vencovsky \& Barriga, 1992).

Vencovsky \& Barriga (1992) afirmam que uma seleção de linhagens vigorosas pressupõe a existência de uma dispersão ou variação genética entre elas, sendo tal dispersão causada por diferentes tipos de componentes genéticos da variação genotípica total, presente na população base. Pelo que foi exposto por Cockerham (1983), não é tarefa fácil descrever-se o perfil completo de uma população, quanto à natureza da variabilidade genética que ela possui, para aquilatar seu potencial como fonte de linhagens. Mesmo assim, sem que empreguem-se modelos genéticos complexos, podese avaliar populações, de modo aproximado, para que se tenha uma visão de suas potencialidades (Vencovsky \& Barriga, 1992).

Diversos trabalhos da literatura, como por exemplo os de Vianna et al. (1982), Lima et al. (1984), Pinto et al. (1989) e Nass \& Miranda Filho (1995), referentes ao estudo da depressão por endogamia em milho, relatam que o método mais direto e curto para a avaliação de um material, quanto ao potencial como fonte de linhagens, é a comparação entre o desempenho de linhagens $S_{1}$ (individualmente ou bulk) e a população parental não endógama.

Conforme Gardner (1965), a média de um caráter numa população panmítica $\left(\mathrm{Y}_{\mathrm{o}}\right)$, supondo número arbitrário de locos, qualquer nível de dominância, mas na ausência de interações epistáticas, pode ser decomposta em:

$$
\hat{Y}_{o}=\mu+\mathbf{a}+\mathrm{d}+\mathrm{e}_{\mathrm{o}}
$$

Se forem feitas autofecundações sucessivas nesta população até que se transforme num conjunto de linhagens puras, a média esperada dessas será:

$$
\hat{Y}_{L}=\mu+\mathbf{a}+\mathbf{e}_{\mathrm{L}}
$$


Nestas médias, 'a' é a contribuição devida aos locos em homozigose e ' $d$ ' aos locos em heterozigose, que coexistem na população original (0), sendo $e_{o}$ e e $e_{L}$ os erros associados as estimativas de $\hat{Y}_{o}$ e $\hat{Y}_{L}$, respectivamente. Autofecundando-se plantas da população uma só vez, a média do caráter nas progênies $S_{1}$ será, no âmbito do modelo admitido:

$$
\hat{Y}_{1}=\mu+a+(1 / 2) d+e_{1}
$$

Com base nas equações 1 e 3 apresentadas, é possível estimar-se $\hat{Y}_{L}$ (equação 3), através de das informações das médias da população original e da progênie $S_{1}$, da seguinte maneira:

$(-)\left\{\begin{array}{c}2 \hat{Y}_{1}=2 \mu+2 \mathrm{a}+\mathrm{d}+2 \mathrm{e}_{1} \\ \hat{Y}_{o}=\mu+\mathrm{a}+\mathrm{d}+\mathrm{e}_{\mathrm{o}}\end{array}\right.$

$$
2 \hat{Y}_{1}-\hat{Y}_{o}=\mu+\mathrm{a}+2 \mathrm{e}_{1}-\mathrm{e}_{\mathrm{o}}
$$

Então, a estimativa de $(\mu+$ a) fica sendo:

$$
(\mu+\mathrm{a})=2 \hat{Y}_{1}-\hat{Y}_{o}
$$

Também, é possivel estimar-se o valor da contribuição devida aos locos em heterozigose (d) do seguinte modo:

$$
\frac{(-) \quad\left\{\begin{array}{l}
\hat{Y}_{o}=\mu+\mathrm{a}+\mathrm{d}+\mathrm{e}_{\mathrm{o}} \\
\hat{Y}_{\mathrm{i}}=\mu+\mathrm{a}+(1 / 2) \mathrm{d}+\mathrm{e}_{1}
\end{array}\right.}{\hat{Y}_{o}-\hat{Y}_{1}=\quad(1 / 2) \mathrm{d}+\mathrm{e}_{\mathrm{o}}-\mathrm{e}_{1}}
$$

Então, a estimativa de $\hat{d}$ fica sendo:

$$
\begin{aligned}
(1 / 2) \hat{d} & =\hat{Y}_{o}-\hat{Y}_{1} \\
\hat{d} & =2\left(\hat{Y}_{o}-\hat{Y}_{1}\right)
\end{aligned}
$$


Portanto, essas equações tornam-se uma ferramenta importante ao melhorista, auxiliando-o na escolha, dentre diversos materiais, aqueles com maior potencial como fonte de linhagens vigorosas, especialmente para produção de grãos. $\mathrm{Na}$ realidade, $(\mu+a)$ é a estimativa da média do caráter da população em completa homozigose, enquanto (d) representa a contribuição dos locos heterozigotos para o caráter.

No Brasil tem havido particular interesse em se conhecer o potencial das populações como fonte de linhagens endogâmicas. Lima et al.(1984), no seu estudo de 32 populações brasileiras, relataram valores médios de $(\mu+$ a) e (d) para produção de grãos $(\mathrm{Kg} / \mathrm{ha})$ de 1120 e 5180; para altura da planta $(\mathrm{cm})$ de 172 e 71; e altura da espiga (cm) de 105 e 47, respectivamente. Vianna et al. (1982) avaliando 14 populações de milho introduzidas no Brasil, quanto a produção de grãos $(\mathrm{Kg} / \mathrm{ha})$, encontraram valores de $(\mu+$ a) variando entre -480 a 250 e (d) variando entre 1360 a 3520 .

Nass (1992) nos estudos das populações semi-exóticas de milho ESALQ PB-1 x Entrelaçado 1 (EE1) e ESALQ PB-1 x Cravo 4 (EC4) encontrou os seguintes valores de $(\mu+\mathrm{a})$ : 195,09 e 202,89 para altura da planta $(\mathrm{cm}) ; 115,94$ e 124,62 para altura da espiga $(\mathrm{cm}) ; 2,57$ e 3,40 para diâmetro da espiga $(\mathrm{cm}) ; 10,92$ e 11,30 para comprimento da espiga $(\mathrm{cm}) ; 8,72$ e 11,57 para estande de 15 plantas/parcela; 1,00 e 5,00 para espigas por parcela; 660,00 e 960,00 para produção de espigas $(\mathrm{Kg} / \mathrm{ha}) ; 468,00$ e 612,00 para produção de grãos $(\mathrm{Kg} / \mathrm{ha})$, respectivamente. Também foram encontrados os seguintes valores de (d) para essas mesmas populações: 73,62 e 69,90 para altura da planta $(\mathrm{cm}) ; 54,24$ e 49,56 para altura da espiga $(\mathrm{cm}) ; 1,34$ e 1,12 para diâmetro da espiga $(\mathrm{cm}) ; 6,50$ e 5,22 para comprimento da espiga $(\mathrm{cm}) ; 5,42$ e 2,84 para estande de 15 plantas/parcela; 11,44 e 8,38 para espigas por parcela; 5712,00 e 8448,00 para produção de espigas $(\mathrm{Kg} / \mathrm{ha})$; 5808,00 e 8808,00 para produção de grãos $(\mathrm{Kg} / \mathrm{ha})$, respectivamente.

Terasawa Júnior (1993) encontrou os seguintes valores de $(\mu+a)$ para a população de milho ESALQ PB- $2 C_{3}$ e ESALQ PB- $3 C_{3}: 1220,0$ e 960,0 para produção (Kg/ha); 197,1 e 189,0 para altura da planta $(\mathrm{cm}) ; 112,4$ e 106,3 para altura da 
espiga $(\mathrm{cm})$, respectivamente. E encontraram os seguintes valores de (d) para essas mesmas populações: 4607,0 e 4393,0 para produção (Kg/ha); 37,7 e 36,3 para altura da planta $(\mathrm{cm}) ; 23,6$ e 20,6 para altura da espiga $(\mathrm{cm})$, respectivamente.

Pinto et al. (1989) analisaram a metodologia apresentada por Gardner \& Eberhart (1966) quanto a estimação da depressão causada pela endogamia em linhagens obtidas ao acaso em oito populações de milho. Os autores relataram que, como os efeitos de dominância estão intimamente relacionados com a endogamia, é possível que as estimativas de efeitos aditivos ou média de todas as linhagens homozigóticas $(\mu+$ a) sejam sub-estimadas, como conseqüência de uma provável super-estimação dos efeitos de dominância. Considerando-se a linearidade do efeito de dominância no modelo proposto por Gardner \& Eberhart (1966), pressupõe-se que continuando-se com a endogamia o caráter produção de grãos continue a cair proporcionalmente. Assim, uma super-estimação dos efeitos da endogamia agrava o problema nas gerações mais avançadas, levando à obtenção de estimativas irreais (negativas) de produção de grãos para linhagens. A linearidade da depressão por endogamia, pressuposta no cálculo da média das linhagens puras, existe na ausência de alelos recessivos deletérios de efeito forte e/ou letais. Se a carga genética for muito grande a linearidade entre o coeficiente de endogamia (F) e a depressão deixa de existir. Portanto, a linearidade existe na redução da contribuição dos locos em heterozigose supondo que a contribuição desses é maior que a dos homozigotos.

Lima et al. (1984) explicaram a ocorrência de valores de $(\mu+a)$ negativos como uma conseqüência de erro experimental ou devida a uma homozigosidade maior do que a proporção esperada (50\% para as linhagens $\mathrm{S}_{1}$ ); complementam, ainda, que há possibilidade da ocorrência do efeito epistático de outros sistemas genéticos (outros pares de genes) sobre os genes controlando os caracteres produção de grãos, altura da planta e altura da espiga.

Diversos trabalhos têm mostrado que os efeitos de epistasia, caso ocorram, são de baixa magnitude ou se anulam na obtenção das médias (Castro et al., 1968; Hallauer \& Sears, 1973; Vianna et al., 1982; Pinto et al., 1985; Pinto et al., 1989). 
Assim, a utilização de uma única geração de autofecundação, embora não permita o cálculo adequado da média das linhagens puras, pode fornecer uma aproximação, permitindo a formação de mais um critério para a seleção de populações para obtenção de linhagens.

Modelos lineares e quadráticos foram ajustados visando relacionar o desempenho médio das gerações de autofecundação para vários caracteres com a porcentagem de homozigose. Verificou-se que, para o caráter produção de grãos , ocorreu um decréscimo, essencialmente linear, com o aumento da homozigose, sendo que os desvios do modelo linear entre as gerações de endogamia parecem ser indicativos da presença de epistase, a qual parece ser de menor importância (Robinson \& Cockerham, 1961; Good \& Halluer, 1977).

Por outro lado, Hallauer \& Miranda Filho (1988), referindo-se à estudos de endogamia feito por diversos autores, concluíram que um modelo de regressão linear parece ser apropriado para descrever o desempenho médio de diferentes gerações de endogamia, e que em muitos casos as proporções das somas de quadrados explicam mais de $90 \%$ do modelo de regressão linear. Contudo, a taxa de decréscimo do desempenho médio das populações endogâmicas não foi totalmente explicada por um modelo simples com valores genotípicos positivos e sem epistasia.

\subsection{Componentes da produção de grãos}

Tendo em vista que a produção de grãos no milho é altamente afetada pela depressão por endogamia, como apresentado no ítem anterior, e que isso acarreta limitações em programas de obtenção de linhagens, estudos mais detalhados sobre esse assunto quanto a compreensão da contribuição dos componentes da produção para a queda do vigor desse caráter poderiam auxiliar muito na escolha de materiais com menor depressão por endogamia. 
Sabe-se que a produção de grãos nas diversas culturas é um caráter complexo. Duncan et al. (1978) reconhecem esse caráter como resultante da associação de um complexo de processos de desenvolvimento, além do período de enchimento de grãos. Em razão disso tem sido investigada com base em seus componentes individuais, tais como: comprimento da espiga, diâmetro da espiga, número de fileiras de grãos, número de grãos por fileira, número de espigas, peso de 100 grãos e peso médio do grão.

Dentre os componentes da produção em milho pode-se destacar quatro principais: número de fileiras de grãos, número de grãos por fileira, número de espigas e peso médio do grão. Quando estes componentes são medidos com bastante precisão e expressos em unidades apropriadas seu produto é a produção de grãos. Grafius (1959), que propôs essa concepção geométrica para produção, sugere que a produção de grãos possa ser eficientemente aumentada pela seleção de um ou mais componentes da produção.

A análise da produção de grãos dentro de seus componentes pode prover hipóteses dentro das causas básicas da variação na produção de grãos, o que permite ao melhorista de plantas estabelecer estratégias eficientes para o melhoramento da produção de grãos ou outros caracteres em cereais. Por exemplo, a análise dos componentes da produção pode: (i) indicar qual componente contribui para os objetivos específicos do melhoramento (McMullan et al., 1988); (ii) gerar hipóteses que permitam maiores ganhos de produção (Payne et al., 1986); e (iii) mostrar quais genes para um componente específico da produção poderia ser usado para aumentar a produção quando incorporado em um conjunto gênico elite, assumindo que a compensação entre a interação dos componentes da produção pode ser minimizada (Frey, 1988; Rasmusson, 1987).

Os componentes da produção primeiramente foram objeto de interesse em milho, quando Leng $(1953,1954)$ os considerou como tais. Este autor tomou a produção como expressa por quatro componentes primários (número de espigas por planta, número de fileiras, número de grãos por fileira e peso médio do grão) e dois secundários (número de grãos por espiga e peso de grãos). Nessas bases, efetuando um 
estudo com 92 híbridos diferentes e as respectivas linhagens parentais, observou que, em relação às linhagens parentais mais produtivas, os híbridos eram inferiores em número de espigas por planta, aproximadamente idênticos quanto ao número de fileiras, cerca de $8 \%$ superiores em peso dos grãos e 42 \% superiores em número de grãos por fileira.

Grafius (1959) estudando os componentes da produção em cevada, desenvolveu um esquema geométrico para explicar a produção, sendo que essas considerações feitas pelo autor foram estendidas para a cultura do milho. Grafius (1960) reconhece os componentes da produção (W) no milho numa função multiplicativa (W=R.S.T.U ), onde estão envolvidos os caracteres: número de espigas (R), número de grãos por fileira (S), número de fileiras de grãos (T) e peso médio do grão (U). Observase que, se estes componentes não são correlacionados, diferentes grupos de genes devem atuar sobre cada componente, não existindo um grupo de genes para a produção em si. Este modelo, então, foi transformado para a escala logarítmica, o que fez com que ele se torne aditivo, permitindo que a contribuição dos componentes da produção seja mais facilmente visualizada. Tal fato foi posteriormente confirmado por Driscoll \& Abel (1976) e Piepho (1995), sendo que este último comprova haver correlação entre os logaritmos dos componentes e os próprios componentes não transformados. Apesar dessa transformação ter sido demonstrada adequada para fazer comparações entre diferentes populações, ela não reflete biologicamente bem a participação de componentes que apresentem valores menores que um, como é o caso do peso médio do grão. Isso porque, uma vez que passam a depender da escala logarítmica, podem assumir valor negativo, o que se torna biologicamente incorreto. Para corrigir isso, pode-se simplesmente tomar a unidade de medida do peso médio do grão transformada de gramas para miligramas.

O emprego dessa metodologia desenvolvida por Grafius (1960) é encontrada em poucos trabalhos na literatura. Tavares (1972), por exemplo, estudou o modo pelo qual os componentes da produção em milho contribuem para a produção em seis populações de milho, a saber: Centralmex, ETO-Colômbia, Piracar, WP-25, WP-17 e WP-4. O autor verificou que, além dos componentes manifestarem respostas com 
magnitudes diferentes em relação à produção, o relacionamento entre os componentes foram particulares para cada uma destas populações, observando, assim, um efeito de compensação entre eles, o que é concordante com a biologia da planta. Os componentes que mais contribuíram para a produção foram número de grãos por fileira e número de fileiras, com cerca de $72 \%$ e $55 \%$, respectivamente.

Métodos de interpretação da compensação dos componentes da produção foram estudados por Grafius (1960), Tavares (1972), Driscoll \& Abel (1976) e Payne et al. (1986). Em todos esses estudos há concordância de que a compensação é efeito da competição por limite de recursos do meio.

Stoskopf \& Reinbergs (1966) afirmaram que o caráter número de grãos por espiga era o melhor componente para a seleção para produção em cereais. Isso pode estar correto, mas resultados de Smail et al.(1986) indicaram que, com o forte efeito pleiotrópico dos dados sobre esse caráter, qualquer processo de seleção compensaria essa diferença no aumento com uma redução no valor de outro componente. Puri et al. (1981) sugerem que, combinando grãos por espiga e peso de grãos dentro do parâmetro de seleção (peso de espiga), seria o método mais eficiente para aumentar a produção.

Deve-se novamente ressaltar que são poucos os trabalhos na literatura que empregam esta metodologia para estudo dos componentes da produção, e especialmente na cultura do milho são muito escassos. Todavia, em outras culturas observam-se alguns registros do emprego dessa metodologia, como por exemplo em sorgo e soja (Wahua \& Miller, 1978), trigo (Alexander et al., 1984), cevada (Smail et al., 1986) e aveia (Payne et al., 1986 e Moser \& Frey, 1994).

Em programas de melhoramento de milho, um dos objetivos mais importantes têm sido conhecer o potencial genético do caráter produção de grãos para se efetuar a seleção para aumento deste importante caráter. Na literatura há enorme volume de estimativas de parâmetros genéticos disponíveis referindo-se não só à produção de grãos, mas também a seus componentes, sendo que as estimativas de maior destaque são a herdabilidade $\left(h^{2}\right)$ e a correlação genética $\left(r_{G}\right)$. 
Para o caráter produção de grãos a literatura apresenta diversos trabalhos nos quais as estimativas de herdabilidade são em torno de 10\%, como por exemplo citam-se, Miranda Filho et al. (1972), Lima \& Paterniani (1977), Miranda Filho et. al. (1977), Crisóstomo (1978), Sawazaki (1979), Reis (1981) e Soares Filho (1987).

Alguns autores fizeram extensas pesquisas na literatura sobre a herdabilidade da produção de grãos. Ramalho (1977) em extenso levantamento sobre estimativas de parâmetros genéticos e fenotípicos em populações de milho da ESALQ/USP verificou uma estimativa média de 9,67\% para o coeficiente de herdabilidade para o caráter produção de grãos. Sampaio (1986), realizando revisão sobre trabalhos que envolviam estimativas de parâmetros genéticos no Departamento de Genética da ESALQ, encontrou estimativas de herdabilidade no sentido restrito para o caráter produção de grãos variando em torno de 10\%. Hallauer \& Miranda Filho (1988), a partir de um grande número de estimativas de diversas populações e híbridos de milho, encontraram uma herdabilidade média, ao nível de médias das parcelas, para a produção de grãos de $18,7 \%$.

Tatis (1990) avaliando as populações originais de Piranão VD-2-MI-O e Piranão VF-1-MI-O encontrou valores de herdabilidade no sentido restrito, ao nível de médias, de 44,35\% e 42,91\% para a produção de grãos da parcela. Patemiani (1995) avaliando duas populações denominadas de A e B, que foram sintetizadas a partir das populações ESALQ PB-2 e ESALQ PB-3, respectivamente, encontrou estimativas de herdabilidade de $49,48 \%$ e $59,32 \%$ para a produção de grãos. Valores de herdabilidade variando de 38,0\% a 54,8\% são relatados por Grombacher et al. (1989), Silva (1991), Holthaus \& Lamkey (1995), Malvar et al. (1996) e Austin \& Lee (1998).

Quanto à herdabilidade dos componentes da produção a literatura está repleta de inúmeros trabalhos que mostram que os componentes da produção apresentam média a alta herdabilidade. Para o caráter número de espigas foram encontradas herdabilidades de 84,6\% (Vianna, 1977), 81,3\% (Regazzi, 1978), 39,0\% (Hallauer \& Miranda Filho, 1988), 83,0\% (Reis, 1981), 61,6\% (Soares Filho, 1987), 78,3\% (Mauro, 1990) e 68,5\% (Ribeiro, 1990). Para o caráter número de grãos por fileira os valores 
encontrados foram de 46,0\% (Paterniani, 1995), 39,0 a 62,0\% (Tatis, 1990) e 37,0 a 39,0\% (Mariote, 1993). Para o caráter número de fileiras de grãos os valores encontrados foram de 57,0\% (Hallauer \& Miranda Filho, 1988), 57,0 a 61,0\% (Tatis, 1990), 55,0 a 61,0\% (Mariote, 1993), 73,0\% (Paterniani, 1995) e 85,1\% (Sawazaki, 1996). Foram encontrados para o caráter peso de 100 grãos os valores de herdabilidade de 78,6\% (Mauro, 1990), 78,70 \% (Silveira, 1990), 58,7\% (Tatis, 1990), 84,9\% (Silva, 1991) e 90,0\% (Sawazaki, 1996), para o peso de 50 grãos valores de 88,1\% (Vianna, 1977) e $80,94 \%$ (Ribeiro, 1990) e para o peso de 300 grãos o valor de $89,2 \%$ (Paterniani, 1995).

Cabe ressaltar aqui que para o caráter peso médio do grão não foi encontrado nenhum valor de herdabilidade na literatura. Entretanto, uma vez que, no presente trabalho, os valores para o caráter peso médio do grão foram obtidos com base nos valores de peso de 500 grãos, considera-se que a herdabilidade do peso médio do grão é alta, em semelhança ao do peso de grãos contados.

Outros caracteres relacionados com a produção também merecem destaque pelo fato de apresentarem média ou alta herdabilidade, a qual também pode ser levada em conta na seleção para produção de grãos. Pode-se citar valores de herdabilidade variando de $65,5 \%$ a $89 \%$ para altura da planta (Tatis, 1990; Holthaus \& Lamkey, 1995), 67,6\% a 90,0\% para altura da espiga (Tatis, 1990; Holthaus \& Lamkey, 1995), 56,0\% a 84,0\% para comprimento da espiga (Grombacher et al., 1989; Tatis, 1990; Holthaus \& Lamkey, 1995; Austin \& Lee, 1998), 69,0\% a 86,0\% para diâmetro da espiga (Grombacher et al., 1989; Tatis, 1990; Holthaus \& Lamkey, 1995; Austin \& Lee, 1998), $45,0 \%$ a $71,0 \%$ para prolificidade (Holthaus \& Lamkey, 1995) e 57,0\% a $71,0 \%$ para comprimento do grão (Grombacher et al., 1989; Tatis, 1990; Holthaus \& Lamkey, 1995; Malvar et al., 1996).

O estudo das correlações entre caracteres tem grande importância no melhoramento de plantas, uma vez que a seleção para um caráter pode aumentar ou diminuir a expressão de outro, dependendo da correlação genética aditiva entre eles. Esse efeito indireto é conhecido como resposta correlacionada à seleção (Ribeiro, 1990). 
Souza Júnior et al. (1985) avaliando a variedade BR-105 verificaram que a seleção para prolificidade provocou ganhos genéticos altos $(16,6 \%)$ na produção de grãos por planta. Motto \& Moll (1983) realizaram extensa revisão sobre a prolificidade e destacaram-na como o critério mais promissor de seleção para produção de grãos em milho. Esses autores verificaram que a prolificidade, além de ser um componente da produção de fácil mensuração, também apresenta herdabilidade satisfatória para os programas de seleção.

$\mathrm{Na}$ literatura a maioria dos trabalhos mostra valores de correlações positivas e significativas entre a produção e seus componentes, entretanto, deve-se ressaltar que a correlação entre caracteres, assim como a herdabilidade varia de acordo com o material avaliado, demonstrando uma amplitude bem variável até para um mesmo caráter avaliado. Verificam-se correlações genéticas positivas e significativas entre a produção de grãos e os seguintes componentes da produção: 0,58 a 0,96 para o número de espigas (Regazzi, 1978; Torres, 1978; Reis, 1981; Cruz, 1983; Mauro, 1990), 0,45 a 0,75 para o número de grãos por fileira (Naspolini Filho, 1975; Tyagi et al.,1988; Pereira, 1990), 0,57 a 0,71 para o peso de 100 grãos (Gomide, 1980; Cruz, 1983; Tyagi et al.,1988; Pereira, 1990; Silva, 1991) e 0,57 a 0,64 para o peso de 50 grãos (Naspolini Filho, 1975; Ribeiro, 1990). Para o caráter número de fileiras de grãos tem-se verificado correlações não significativas (Naspolini Filho, 1975; Tyagi et al.,1988; Grombacher et al., 1989; Holthaus \& Lamkey, 1995).

Como o melhoramento não se processa, na maioria dos casos, visando um único caráter, mas sim o melhoramento simultâneo de vários caracteres, o conhecimento das correlações entre caracteres se faz importante para que o melhorista possa atuar da melhor maneira a maximizar a produção. Há referências de trabalhos onde se estudam as relações entre caracteres que levem à uma maior produção de grãos (Souza Júnior et al., 1985; Mauro, 1990). Além disso, os estudos de correlações têm grande importância em programas de melhoramento, principalmente quando a seleção de um caráter desejável apresenta dificuldade, por tratar-se de um caráter de baixa herdabilidade e/ou com problemas de medição e identificação (Cruz, 1983). Nesse aspecto encaixa-se o caráter produção de grãos, o qual apresenta herdabilidade baixa. 
Dudley \& Moll (1969) comentam que é importante se conhecer a magnitude da herdabilidade dos caracteres, bem como das correlações, para se ter idéia da eficiência da seleção conjunta para diferentes caracteres. Segundo Robinson et al. (1951) a seleção, utilizando-se além do caráter de interesse, outros caracteres correlacionados, como é feito no índice de seleção, leva a ganhos maiores, se os pesos dados a cada caráter na seleção possuírem o mesmo sinal da correlação genética com o caráter de interesse, como no caso de se usar a altura da planta e a altura da espiga, com pesos positivos, quando se está interessado em selecionar para produção de grãos em milho, por exemplo. $\mathrm{O}$ mesmo não ocorre quando se dão pesos negativos a esses caracteres: nesse caso, os ganhos na produção de grãos serão menores do que se fosse feita a seleção usando-se somente o caráter produção.

Por outro lado, quando o estudo envolve a correlação entre os componentes da produção, os resultados divergem tanto em magnitude quanto em sinal. Entretanto, as evidências apontam para correlações nulas entre o número de espigas e o número de grãos por fileira (Naspolini Filho, 1975; Hallauer \& Miranda Filho, 1988), o número de espigas e o número de fileiras de grãos (Torres, 1978; Naspolini Filho, 1975; Hallauer \& Miranda Filho, 1988), o número de fileiras de grãos e o número de grãos por fileira (Naspolini Filho, 1975; Pereira, 1990), o número de grãos por fileira e o peso de 50 grãos (Naspolini Filho, 1975), e o número de fileiras de grãos e o peso de 50 grãos (Naspolini Filho, 1975). Através desses valores de correlação, constata-se que tais componentes da produção devem ser geneticamente independentes.

Verificam-se, por outro lado, correlações genéticas negativas e significativas entre o número de espigas e o peso de 100 grãos (Regazzi, 1978; Cruz, 1983; Mauro, 1990), e o número de espigas e o peso de 50 grãos (Vianna, 1977). Este último autor afirma que ao serem selecionadas plantas que produzam maior número de espigas, seleciona-se também, plantas que produzam grãos menores.

Segundo Teixeira (1978), teoricamente, o aumento da produção poderia ser alcançado incrementando-se os componentes do rendimento separadamente ou em combinações, entretanto, na prática tem-se observado que grandes incrementos em 
um deles geralmente são acompanhados por decréscimos em outros. Estes estudos são particularmente interessantes, como já observaram Moll et al. (1962) e Hardwick \& Andrews (1980), em virtude de que os componentes da produção podem ser medidos com menor erro que a produção "per se".

Levando em consideração os resultados da literatura até aqui abordados, pode-se argumentar que uma vez que todos os componentes da produção apresentam alta herdabilidade e alta correlação com a produção de grãos, podem ser utilizados no processo seletivo de linhagens vigorosas e produtivas, como auxílio na seleção para produção de grãos, especialmente nas gerações iniciais dos programas de melhoramento de obtenção de linhagem, quando o número de linhagens é muito alto. Não deve ser esquecido, entretanto, que a competição entre os componentes da produção, mais especificamente entre o número de espigas e o peso de grãos, podem limitar o progresso a ser obtido na seleção direcionada apenas para um desses dois componentes (Ramalho et al., 1993).

Outro tipo de estudo dos componentes da produção utilizando a metodologia de Grafius (1959) é o de verificar a contribuição de cada um dos componentes da produção em cruzamentos de materiais visando a exploração da heterose. Os componentes referentes a esse aumento devido à heterose são chamados de componentes heteróticos.

A idéia de se estudar a heterose através dos componentes da produção foi inicialmente empregada para a cultura do tomate (Powers $\left.{ }^{2}, 1955\right)$, citado por Tavares (1972), e da cevada (Grafius, 1959), e posteriormente em milho. Tavares (1972) obtendo híbridos simples resultantes de cruzamentos entre seis populações de milho (Centralmex, ETO-Colômbia, Piracar, WP-25, WP-17 e WP-4), observou que os componentes heteróticos que apresentaram as maiores contribuições para o aumento da produção foram o número de grãos por fileira $(70 \%)$ e o peso médio do grão (15\%).

\footnotetext{
${ }^{2}$ Powers, L. Components of variance method and partition method of genetic analysis applied to weight per fruit of tomato hybrid and parental populations. U.S. Dept. of Agricult. Pich. Bulletin 1131. 64p. 1955.
} 
Mehta \& Sarkar (1992), estudando a heterose dos componentes da produção de cruzamentos de oito linhagens de milho, observaram que, em média, a heterose foi significativa para todos os componentes estudados, que foram comprimento da espiga, diâmetro da espiga, número de fileiras, número de grãos por fileira e peso de mil grãos.

Por outro lado, não é encontrado na literatura nenhum tipo de estudo em milho referente a contribuição dos componentes para a diminuição da produção, causada pela depressão por endogamia. 


\section{MATERIAL E MÉTODOS}

\subsection{Material genético}

\subsubsection{Descrição e origem das populações base $\left(S_{0}\right)$}

Para a realização do presente trabalho foram empregados vinte e três cultivares de milho, dentre os quais encontram-se variedades de polinização livre (de base genética ampla e sintéticos), além de diversos híbridos comerciais pertencentes a diversas companhias. A descrição desses materiais encontra-se citada abaixo:

- BR - 106: é uma população de porte baixo, ciclo precoce e grãos amarelos dentados. Foi obtida pelo intercruzamento das variedades de porte alto Centralmex, Composto Dentado e Maya. A seguir, este composto foi cruzado com a população BR-108 (Tuxpeño-1), de ciclo precoce e porte baixo. Após duas gerações de recombinação, seguiram-se três ciclos de seleção para redução da altura da planta e da espiga (Souza Júnior et al., 1993);

- BR- 105: é uma população de porte baixo, ciclo precoce, grãos alaranjados duros e de baixa depressão por endogamia. Originalmente foi denominada de Suwan, tendo sido obtida na Tailândia através da seleção recorrente com progênies $\mathrm{S}_{1}$. Ela foi sintetizada a partir do intercruzamento das raças de milho Cuban Flint, Cuban Dent, Catetos, Tuxpeño, Tusón, Coastal Tropical Flint e germoplasma dos Estados Unidos da América, cruzados com os compostos 1 e 5 das Filipinas com resistência a míldio (Gracen, 1986). Foi introduzida no Brasil em 1976, sendo submetida a 5 ciclos de seleção com progênies de irmãos germanos no Centro Nacional de Pesquisa de Milho e Sorgo (CNPMS)/Empresa brasileira de agropecuária (EMBRAPA) (Souza Júnior et al., 1993); 
- ESALQ PB-4 e ESALQ PB-5: são compostos de base genética ampla obtidos no Departamento de Genética da Escola Superior de Agricultura 'Luiz de Queiroz" (ESALQ). O composto ESALQ PB-4 resultou do cruzamento das populações: Tuxpeño Crema I, MEB I e Antigua GP2, obtendo-se um composto de porte intermediário com predominância de grãos tipo dentado. O composto ESALQ PB-5 originou-se do cruzamento das populações: Eto Blanco, Piracar e Mezcla Amarilla, resultando um composto de porte intermediário e com predominância de grãos tipo duro (flint). Quanto à cor, ambas as populações são segregantes para grãos amarelos e brancos, embora nos ciclos de recombinação tenha sido praticada seleção para cor amarela (Sampaio, 1986);

- IG-1 e IG-2: essas duas populações de polinização aberta possuem ciclo e porte intermediários, segundo a classificação utilizada para fins de avaliação de cultivares em ensaios regionais e nacional, sendo que a população IG-1 possui grãos duros alaranjados e a IG-2 grãos dentados amarelos. A população IG-1 foi obtida pelo intercruzamento das populações CMS-05, oriunda do CNPMS da EMBRAPA e a ESALQ PB-5 do Departamento de Genética da ESALQ, e a seguir foi cruzada com o híbrido simples HS-1. Enquanto a população IG-2 foi obtida pelo intercruzamento das populações CMS-06 do CNPMS e a população ESALQ PB-4 do Departamento de Genética da ESALQ, e a seguir foi cruzada com o híbrido simples HS-2. Cada material foi então recombinado por duas gerações. Os híbridos simples HS-1 e HS-2 são parentais do híbrido duplo BR 201 do CNPMS-EMBRAPA (Souza Júnior ${ }^{3}$ );

\footnotetext{
${ }^{3}$ Souza Júnior, C.L. Departamento de Genética, ESALQ/USP. Comunicação Pessoal.
} 
- HS-1 e HS-2: são populações $F_{2}$ de híbridos simples, sendo ambas de porte e ciclos intermediários, sendo a primeira com grãos duros e alaranjados, e a segunda com grãos dentados amarelos (Souza Júnior ${ }^{4}$ );

Os híbridos empregados neste trabalho bem como sua descrição estão apresentados na Tabela 2 .

Tabela 2. Descrição dos materiais híbridos empregados no presente estudo.

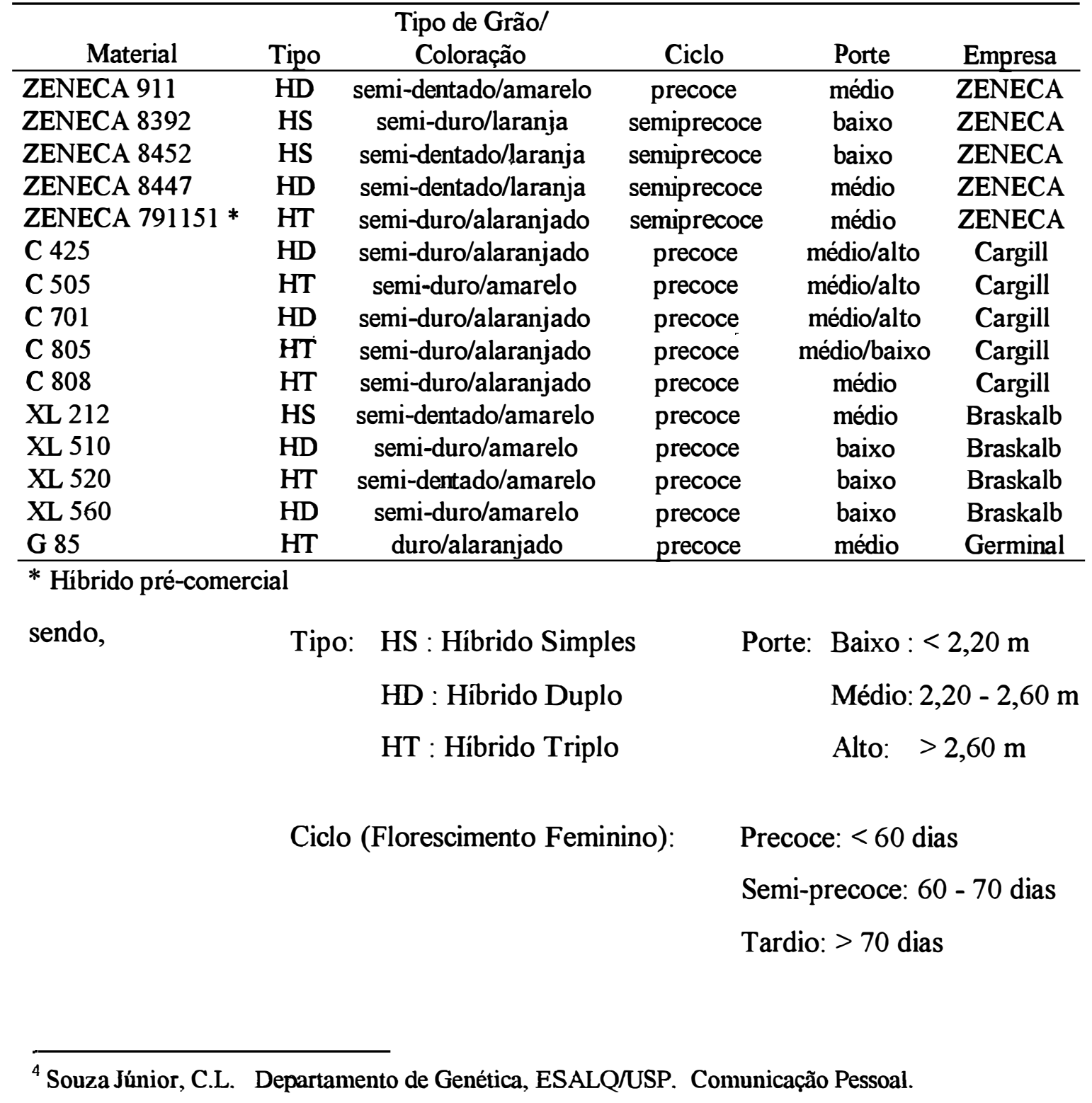


As populações $\left(\mathrm{S}_{0}\right)$ foram multiplicadas por cruzamentos entre plantas tomadas aleatoriamente de cada população no campo experimental da ESALQ, município de Piracicaba/SP. Cerca de 400 plantas por população por hibrido foram utilizadas. Os híbridos foram solicitados às empresas Zeneca, Cargill, Braskalb e Novartis, cujos materiais então identificados por ZENECA, C, XL e G, respectivamente.

\subsubsection{Obtenção do material genético $S_{1}$}

Em outubro de 1992 foram plantados, no campo experimental da ESALQ, município de Piracicaba/SP, lotes contíguos de cada um dos vinte e três materiais referidos no ítem anterior. Foram realizadas cerca de 400 autofecundações para cada tipo de material de plantas parentais $S_{0}$, que apresentavam características agronômicas favoráveis. Por ocasião da colheita selecionaram-se cerca de 380 espigas/material, cujas sementes constituíram o material $\mathrm{S}_{1}$.

\subsection{Métodos}

\subsubsection{Execução experimental}

Os tipos de materiais $S_{0}$ e $S_{1}$, bem como os diferentes materiais genéticos empregados, foram avaliados seguindo um esquema de experimentos em faixas (Steel \& Torrie, 1960), de tal modo que os materiais com um mesmo grau de endogamia ocupassem parcelas adjacentes, isto é, uma faixa com todas os materiais $S_{1}$ contígua a uma faixa com os materiais $S_{0}$, visando a diminuir os efeitos prováveis devido à diferenças de vigor entre $S_{0}$, mais vigorosas, e $S_{1}$. Os tratamentos foram instalados 
segundo o delineamento blocos inteiramente casualizados com 10 repetições por local. Os experimentos foram avaliados no ano agrícola de 1993/94, sendo instalados em três locais da região de Piracicaba, Estado de São Paulo: Fazenda Areão e Fazenda Caterpillar, ambas no município de Piracicaba, e numa área experimental do Departamento de Genética da ESALQ/USP localizado no município de Anhembi.

Nesse esquema experimental as subparcelas foram constituídas dos tipos de materiais $S_{0}$ e $S_{1}$, não endogâmico e endogâmico, de cada genótipo em linhas de $4 \mathrm{~m}$ de comprimento, com espaçamento de 0,20 $\mathrm{m}$ entre plantas, e $0,90 \mathrm{~m}$ entre linhas, sendo a área efetiva de $3,60 \mathrm{~m}^{2}$. Já as parcelas para avaliar os efeitos conjuntos de todos os cultivares foram constituídas por duas linhas como definido anteriormente. Desta forma as parcelas ocuparam uma área de $7,20 \mathrm{~m}^{2}$. Na semeadura foram colocadas 40 sementes por subparcela e, 15 dias após a germinação, foi efetuado o desbaste, procurando-se manter o estande ideal de 20 plantas por subparcela. A densidade populacional foi de aproximadamente 55.555 plantas/ha. As adubações de plantio e cobertura, além do controle de plantas daninhas, foram as normalmente utilizadas para a cultura. Todos os dados foram tomados na subparcela como um todo ou de uma amostra representativa obtida de plantas competitivas dentro destas. Os caracteres avaliados e a forma de avaliação foram:

Altura da planta (AP): média da altura de cinco plantas competitivas, medidas do nível do solo à inserção da folha bandeira $(\mathrm{cm} /$ planta);

Altura da espiga (AE): média da altura das espigas das mesmas cinco plantas competitivas, medidas do nível do solo à inserção da primeira espiga (cm/planta);

Posição relativa da espiga (PRE): este índice indica a posição da primeira espiga em relação à altura da planta. É obtido dividindo-se a altura da espiga pela altura da planta (AE/AP); 
Estande (ES): avaliado contando-se o número total de plantas no momento da colheita;

Número médio de espigas por subparcela (NE): após a pesagem das espigas, efetuou-se a contagem do número total de espigas dentro de cada subparcela;

Número médio de espigas por planta (Prolificidade) (PROL): a variável é calculada dividindo-se o número de espigas pelo número total de plantas da subparcela (espigas/planta). Para esse caráter foram feitas correções para estande médio, utilizandose o método de correção por covariância, descrito por Vencovsky \& Barriga (1992);

Peso de 500 grãos $\left(\mathbf{P G}_{\mathbf{5 0 0}}\right)$ : da parte central da espiga foram tomados ao acaso 500 grãos em uma amostra de cinco espigas por subparcela (em gramas);

Número de grão por fileira (NGF): média do número de grãos por fileira na espiga contados em cinco espigas amostradas na subparcela;

Número de fileiras (NF): média do número de fileiras de grãos por espiga contados em cinco espigas amostradas na subparcela;

Produção de grãos (PROD): esse dado constitui-se de uma estimativa que foi obtida em duas etapas: na primeira, a produção de grãos por subparcela foi obtida através da multiplicação dos seguintes componentes da produção: NE x NF x NGF x Pg, onde Pg é o peso médio do grão obtido da seguinte maneira: $P g=P_{500} / 500$. Na segunda etapa a produção anteriormente obtida na parcela $(\mathrm{Kg} /$ parcela) é extrapolada para a unidade de $\mathrm{Kg} / \mathrm{ha}$ da seguinte maneira:

Cada parcela apresentou um determinado peso de grãos $(\mathrm{Kg})$ associado a um número de plantas (estande). Sendo que em um hectare a densidade populacional corresponde a 55.555 plantas, então tem-se que a produção em um hectare corresponde a: 
Produção de grãos $(\mathrm{Kg} / \mathrm{ha})=$ Produção de grãos da parcela $(\mathrm{Kg}) \times 55.555$ plantas Número de plantas da parcela

Além disso, nas análise de variância para este caráter foram feitas correções para estande médio, utilizando-se o método de correção por covariância (Vencovsky \& Barriga, 1992);

Peso de espigas despalhadas (PE): posteriormente à colheita, as espigas despalhadas foram levadas ao laboratório e deixadas expostas ao ambiente por algum tempo para uniformizar a umidade e, após isto, foi realizada a pesagem $(\mathrm{Kg} /$ parcela), e em seguida os valores obtidos para este caráter foram extrapolados para a unidade de $\mathrm{Kg} / \mathrm{ha}$, conforme o procedimento já explicado anteriormente. Para este caráter também foram feitas correções para estande médio, utilizando-se o método de correção por covariância (Vencovsky \& Barriga, 1992);

Comprimento da espiga (CE): média do comprimento de cinco espigas amostradas na subparcela $(\mathrm{cm})$;

Diâmetro da espiga (DE): média do diâmetro de cinco espigas amostradas na subparcela $(\mathrm{cm})$;

Diâmetro do sabugo (DS): média do diâmetro do sabugo de cinco espigas amostradas na subparcela $(\mathrm{cm})$;

Profundidade do grão (PROF): este dado foi calculado através da seguinte forma: PROF $=($ DE - DS $) / 2($ expresso em $\mathrm{cm})$. 
Com exceção dos caracteres $\mathrm{AP}, \mathrm{AE}$ e PRE, que foram avaliados apenas nos experimentos instalados na Fazenda Caterpillar e na área experimental do Anhembi, todos os demais caracteres foram avaliados nos três locais.

\subsubsection{Análises estatístico-genéticas}

\subsubsection{Análise de variância ao nível de parcela}

Foram feitas análises individuais dos experimentos para cada ambiente segundo o procedimento proposto por Kempthorne (1952), para análise de experimentos em faixas e, a seguir, as análises de variância conjunta envolvendo os três ambientes. As análises de variância para os caracteres estudados, com exceção de produção de grãos, foram realizadas com base nas médias de parcelas.

O modelo matemático para a análise conjunta, segundo Kempthorne (1952), é o seguinte:

$Y_{i k j j}=\mu+c_{i}+b_{j l}+a_{1}+(c a)_{i l}+(c a b)_{(i l j j}+t_{k}+(t a)_{k l}+(t a b)_{(k l) j}+(c t)_{i k}+(c t a)_{i k l}+e_{(i k l) j}$

sendo:

$(i=1,2, \ldots, I ; \quad k=1$ e $2=K ; j=1,2, \ldots, J ; 1=1,2, \ldots, L)$

onde: 
$\mathrm{Y}_{\mathrm{ijk}}$ é o valor observado no tipo de material $\mathrm{k}$ (subparcela), do cultivar $\mathrm{i}$ na repetição $\mathrm{j}$ dentro do local l;

$\mu \quad$ é a média geral (constante);

$\mathrm{c}_{\mathrm{i}} \quad$ é o efeito do cultivar $\mathrm{i}(\mathrm{i}=1,2, \ldots, \mathrm{I})$;

$\mathrm{b}_{\mathrm{j} n} \quad$ é o efeito do bloco $\mathrm{j}(\mathrm{j}=1,2, \ldots, \mathrm{J})$ dentro do local $\mathrm{l}(\mathrm{l}=1,2, \ldots, \mathrm{L})$;

$\mathrm{a}_{1} \quad$ é o efeito do local $1(1=1,2, \ldots, \mathrm{L})$;

(ca) il é o efeito da interação entre o cultivar i e o local l;

(cab) (il)j é o efeito da interação entre o cultivar $\mathrm{i}$, local 1 e bloco $j$, que foi usado como erro experimental ao nível das parcelas, onde se supõe (cab) ${ }_{\text {(ilj }} \sim \mathrm{N}\left(0 ; \sigma_{\text {cab) }}^{2}\right.$;

$t_{k} \quad$ é o efeito do tipo de material $k(k=1,2, \ldots, K)$;

$(\mathrm{ta})_{\mathrm{kl}} \quad$ é o efeito da interação entre o tipo de material k e o local l;

$(\mathrm{tab})_{(\mathrm{kl}) j}$ é o efeito da interação entre o tipo de material $\mathrm{k}$, local $1 \mathrm{e}$ bloco $\mathrm{j}$, que foi usado como erro experimental ao nível das subparcelas, onde se supõe $\left(\right.$ tab) ${ }_{(\mathrm{kl}) \mathrm{j}} \sim \mathrm{N}\left(0 ; \sigma_{\mathrm{tab}}^{2}\right)$;

(ct) ik é o efeito da interação entre o cultivar i e o tipo de material k;

(cta) $)_{\mathrm{ikl}}$ é o efeito da interação entre o cultivar i com o tipo de material k e o local l;

$e_{(i k) j} \quad$ é o erro experimental que surge devido a fatores não controlados no modelo, onde se supõe $e_{(i k l j j} \sim N\left(0 ; \sigma^{2}\right)$;

O modelo adotado foi considerado fixo, uma vez que os cultivares estudados não representam nenhuma população, os tipos de materiais são apenas dois $\left(\mathrm{S}_{1}\right.$ e $\mathrm{S}_{0}$ ), e os locais contrastantes não representam nenhuma região em particular.

$\mathrm{O}$ esquema da análise de variância conjunta com os graus de liberdade e o teste $\mathrm{F}$, seguindo a estrutura dos experimentos em faixa num modelo fixo, além das esperanças matemáticas dos quadrados médios, é apresentado na Tabela 3. 


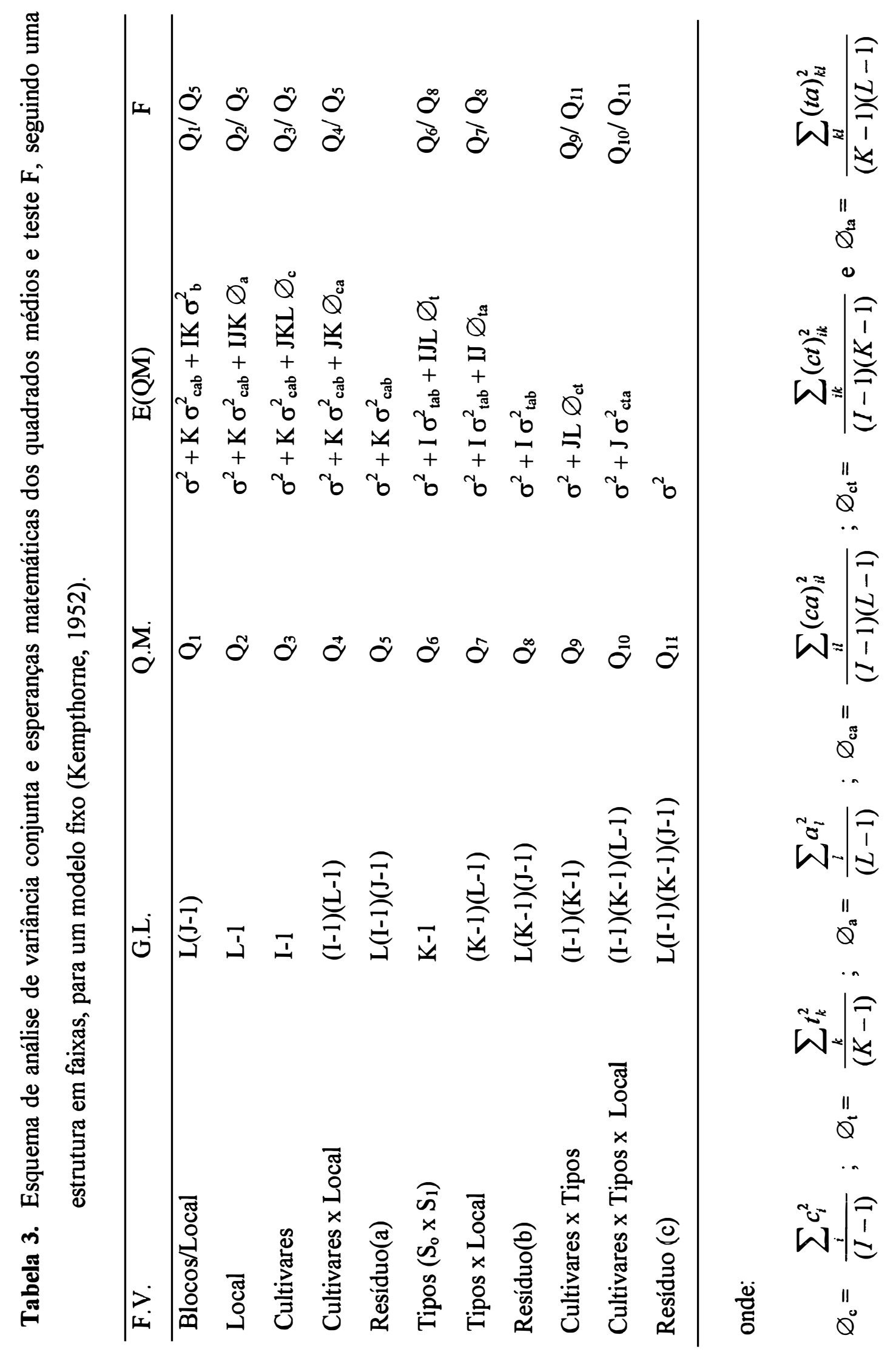


As hipóteses testadas neste modelo são:

$\mathrm{H}_{0}(1): \mathrm{c}_{\mathrm{i}}=0 \quad$ nenhum efeito de cultivar difere de zero;

$\mathrm{H}_{0}(2): t_{k}=0 \quad$ nenhum efeito de tipo de material difere de zero;

$\mathrm{H}_{0}(3): \mathrm{a}_{1}=0 \quad$ nenhum efeito de ambiente difere de zero;

$\mathrm{H}_{0}(4)$ : $(\mathrm{ct})_{\mathrm{ik}}=0 \quad$ nenhum efeito de interação entre cultivar e tipo de material difere de zero;

$\mathrm{H}_{0}(5)$ : (ca) $)_{i 1}=0 \quad$ nenhum efeito de interação entre cultivar e ambiente difere de zero;

$\mathrm{H}_{0}(6):(\mathrm{ta})_{\mathrm{kl}}=0 \quad$ nenhum efeito de interação entre tipo de material e ambiente difere de zero;

$\mathrm{H}_{0}$ (7): (cta) $)_{\text {ikl }}=0$ nenhum efeito de interação entre cultivar, tipo de material e ambiente difere de zero;

Com a finalidade de poder discriminar melhor as diferenças entre os materiais estudados, a análise estatística para a fonte de variação cultivares teve seqüência realizando-se uma divisão em dois grandes grupos, com decomposição ortogonal dos graus de liberdade, a saber: híbridos e variedades de polinização livre. A seguir estes grupos foram subdivididos, sendo o grupo dos híbridos compreendidos por três subgrupos: híbridos simples, triplos e duplos; e as variedades de polinização livre compreendidas por dois subgrupos: variedades de base genética ampla (BR-106, ESALQ PB-4 e ESALQ PB-5) e pelas variedades sintéticas (HS-1, HS-2, IG-1, IG-2 e BR-105).

Na Tabela 4 são apresentados os desdobramentos possiveis das fontes de variação, necessários para explorar as informações geradas no experimento e discriminar as diferenças entre os grupos e subgrupos de materiais. 
Tabela 4. Esquema de análise da variância conjunta seguindo uma estrutura em blocos casualizados e desdobramentos do efeito de cultivares.

\begin{tabular}{|c|c|c|c|}
\hline C.V. & GL & $\mathrm{QM}$ & $\mathrm{F}$ \\
\hline Blocos/Locais & 27 & $\mathrm{Q}_{1}$ & $\mathrm{Q}_{1} / \mathrm{Q}_{17}$ \\
\hline Locais & 2 & $\mathrm{Q}_{2}$ & $\mathrm{Q}_{2} / \mathrm{Q}_{17}$ \\
\hline Cultivares & 22 & $\mathrm{Q}_{3}$ & $\mathrm{Q}_{3} / \mathrm{Q}_{17}$ \\
\hline Híbridos(H) & 14 & $\mathrm{Q}_{4}$ & $\mathrm{Q}_{4} / \mathrm{Q}_{17}$ \\
\hline Híbridos Simples(HS) & 2 & $\mathrm{Q}_{5}$ & $\mathrm{Q}_{5} / \mathrm{Q}_{17}$ \\
\hline Híbridos Triplos (HT) & 5 & $\mathrm{Q}_{6}$ & $\mathrm{Q}_{6} / \mathrm{Q}_{17}$ \\
\hline Híbridos Duplos(HD) & 5 & $\mathrm{Q}_{7}$ & $\mathrm{Q}_{7} / \mathrm{Q}_{17}$ \\
\hline HS vs HT & 1 & $\mathrm{Q}_{8}$ & $\mathrm{Q}_{8} / \mathrm{Q}_{17}$ \\
\hline HS vs HD & 1 & $\mathrm{Q}_{9}$ & $\mathrm{Q}_{9} / \mathrm{Q}_{17}$ \\
\hline (HT vs HD) $)^{*}$ & (1) & $\left(Q_{10}\right)$ & $\left(Q_{10} / Q_{17}\right)$ \\
\hline Variedades(Var) & 7 & $Q_{11}$ & $\mathrm{Q}_{11} / \mathrm{Q}_{17}$ \\
\hline Base Gen. Ampla(BGA) & 2 & $\mathrm{Q}_{12}$ & $\mathrm{Q}_{12} / \mathrm{Q}_{17}$ \\
\hline Sintéticos(Sint) & 4 & $\mathrm{Q}_{13}$ & $\mathrm{Q}_{13} / \mathrm{Q}_{17}$ \\
\hline BGA vs Sint & 1 & $\mathrm{Q}_{14}$ & $\mathrm{Q}_{14} / \mathrm{Q}_{17}$ \\
\hline H vs Var & 1 & $Q_{15}$ & $\mathrm{Q}_{15} / \mathrm{Q}_{17}$ \\
\hline Cultivares $x$ Locais & 44 & $Q_{16}$ & $\mathrm{Q}_{16} / \mathrm{Q}_{17}$ \\
\hline Resíduo(a) & 594 & $\mathrm{Q}_{17}$ & \\
\hline $\operatorname{Tipos}\left(\mathrm{S}_{\mathrm{o}} \times \mathrm{S}_{1}\right)$ & 1 & $\mathrm{Q}_{18}$ & $\mathrm{Q}_{18} / \mathrm{Q}_{20}$ \\
\hline Tipos $\times$ Locais & 2 & $Q_{19}$ & $\mathrm{Q}_{19} / \mathrm{Q}_{20}$ \\
\hline Resíduo(b) & 27 & $\mathrm{Q}_{20}$ & \\
\hline Cultivares $x$ Tipos & 22 & $\mathrm{Q}_{21}$ & $\mathrm{Q}_{21} / \mathrm{Q}_{23}$ \\
\hline Cultivares $\mathrm{x}$ Tipos $\mathrm{x}$ Locais & 44 & $\mathrm{Q}_{22}$ & $\mathrm{Q}_{22} / \mathrm{Q}_{23}$ \\
\hline Resíduo (c) & 594 & $\mathrm{Q}_{23}$ & \\
\hline
\end{tabular}

Todas as análises dos dados foram realizadas utilizando-se o programa computacional SAS (Statistical Analysis System, SAS, 1992). As médias dentro de cada tipo de material foram comparadas através de diferença mínima significativa (DMS) ao nível de $5 \%$ de probabilidade.

\footnotetext{
• Contraste não ortogonal
} 


\subsubsection{Estimativa da depressão por endogamia}

A depressão por endogamia para todos os cultivares e para todos os caracteres em estudo, foi estimada como um desvio percentual em relação à média da população não endógama. A depressão média foi assim calculada:

$$
D E \%=\left[\left(S_{0}-S_{1}\right) / S_{0}\right] .100
$$

onde: DE\% : é a depressão por endogamia média em porcentagem;

$S_{0}$ : é a média da população $S_{0}$;

$S_{1}$ : é a média da população $S_{1}$.

Utilizou-se, ainda, a técnica de Gardner (1965) que permite a obtenção de informações genéticas a partir das médias das populações. As médias das populações $S_{0}$ e $S_{1}$ são representadas, respectivamente por:

$$
\begin{aligned}
& S_{0}=\mu+a+d \\
& S_{1}=\mu+a+d / 2
\end{aligned}
$$

onde: $\mu$ : é a média geral

a : é o componente aditivo

d : é o componente dominante

Desse modo foi possível estimar os componentes de médias das duas populações:

$$
\begin{gathered}
(\mu+a)=\left(2 S_{1}\right)-S_{0} \\
d=2\left(S_{0}-S_{1}\right)
\end{gathered}
$$


onde:

$\mu$ : é a média dos homozigotos;

a $: \sum_{i}\left(p_{i}-q_{i}\right) a_{i}$, e representa a contribuição dos locos em homozigose na média do caráter, sendo $p_{i}$ e $q_{i}$ as freqüências gênicas para o loco i (Vencovsky, 1987);

d : $2 \sum_{i} p_{i} q_{i} d_{i}$, e refere-se a contribuição dos locos em heterozigose para a média do caráter.

Além disso, a proporção entre $(\mu+a)$ e $(d)$ foi estimada pela razão $(\mu+a) /(d)$ para cada material e em cada caráter.

\subsubsection{Componentes da produção}

O estudo dos componentes da produção foi baseado no modelo de Grafius (1960), que considerou a produção como uma função onde os seguintes caracteres são multiplicativos: número de espigas (NE), número de fileiras de grãos (NF), número de grãos por fileira (NGF) e peso médio do grão $(\mathrm{Pg})$, em miligramas, sendo este último caráter obtido por: $\mathrm{Pg}=\mathrm{PG}_{500} / 500$. Assim sendo, a produção foi obtida através da expressão:

\section{Produção (mg/parcela) $=$ NE x NF x NGF x Pg}

A seguir foi realizada a transformação para a escala logarítmica, seguindo a metodologia aplicada por Grafius (1960), convertendo-se a função na seguinte soma:

$$
\log _{10}(\text { Produção })=\log _{10}(\mathrm{NE})+\log _{10}(\mathrm{NF})+\log _{10}(\mathrm{NGF})+\log _{10}(\mathrm{Pg})
$$


Procedeu-se essa operação tanto para o material $\mathrm{S}_{0}$ como para $\mathrm{S}_{1}$ em cada grupo estudado. A seguir foram estimadas as participações de cada componente da produção de grãos, em porcentagem $(\% \mathrm{C})$, em relação ao valor do logaritmo da produção de grãos do seguinte modo:

$$
\% \mathrm{C}=\left[\log _{10}(\mathrm{C}) / \log _{10}(\text { Produção })\right] .100 \text {, }
$$

,onde C é qualquer um dos componentes: NE, NF, NGF ou Pg.

A depressão por endogamia sofrida pela produção de grãos e seus componentes foi obtida por meio da diferença entre os valores de seus logaritmos, de acordo com o esquema a seguir:

(1) Material $\mathrm{S}_{0}: \quad \log _{10}($ Produção $)=\log _{10}(\mathrm{NE})+\log _{10}(\mathrm{NF})+\log _{10}(\mathrm{NGF})+\log _{10}(\mathrm{Pg})$

(2) Material $S_{1}: \quad \log _{10}($ Produção $)=\log _{10}(\mathrm{NE})+\log _{10}(\mathrm{NF})+\log _{10}(\mathrm{NGF})+\log _{10}(\mathrm{Pg})$

Fazendo-se (1) - (2) tem-se:

$$
\operatorname{Dif}(\text { Produção })=\operatorname{Dif(NE)}+\operatorname{Dif}(N F)+\operatorname{Dif}(N G F)+\operatorname{Dif}(P g)
$$

sendo,

$$
\text { Dif }=\text { Diferença entre os logaritmos. }
$$

A seguir a diferença dos componentes, $\operatorname{Dif}(\mathrm{C})$, foi transformada em porcentagem em relação a diferença da produção de grãos, \% $\operatorname{Dif}(\mathrm{C})$ :

$\% \operatorname{Dif}(\mathrm{C})=\left\{\log _{10}[\operatorname{Dif}(\mathrm{C})] / \log _{10}[\operatorname{Dif}(\operatorname{Produção})]\right\} .100$,

,onde $\mathrm{C}$ é qualquer um dos componentes: NE, NF, NGF ou Pg.

Assim, as depressões por endogamia, portanto, passam a exprimir diferenças e porcentagens dadas pelos logaritmos dos componentes da produção de grãos, o que permite analisar a contribuição de cada um dos componentes para a redução da produção de grãos. 
Justificam-se estas transformações para a escala logarítmica por, principalmente, evidenciar melhor a participação de cada componente tanto na função que expressa a produção de grãos, como na que expressa a depressão da produção, especialmente quando se considera porcentagens.

A unidade de trabalho da produção de grãos, miligramas/parcela, é resultante da utilização da unidade miligramas para o caráter peso médio do grão. $\mathrm{O}$ emprego dessa unidade para o caráter peso médio do grão foi necessário para que os valores se tomassem números inteiros e, portanto, sejam positivos ao serem transformados para a escala logarítmica de base 10 . 


\section{RESULTADOS E DISCUSSÃO}

\subsection{Análise geral dos resultados}

Em razão do grande número de caracteres avaliados, serão discutidos a seguir os valores médios experimentais para os cultivares e seus tipos de materiais $\left(\mathrm{S}_{\mathrm{o}}\right.$ e $\mathrm{S}_{\mathrm{I}}$ ) de cada um dos três locais e médias dos locais, para apenas os dois caracteres de maior importância agronômica: a produção de grãos (PROD) e o peso de espigas despalhadas (PE). Além disso, serão comentados os coeficientes de variação experimental das análises individuais (por local) e conjunta (Tabelas 5 e 6).

Observou-se uma diferença nítida entre as médias dos materiais nos três locais avaliados, tanto para o caráter PE quanto para PROD. As médias, tanto de $\mathrm{S}_{\mathrm{o}}$ quanto de $S_{1}$ para o caráter PE foram nitidamente maiores no local Areão, seguido de Caterpillar e depois Anhembi; já para o caráter PROD as médias foram maiores no local Caterpillar, seguido de Areão e depois Anhembi. As médias dos grupos de materiais avaliados (híbridos e variedades) apresentaram diferenças de um local para outro, sendo que a média do grupo dos híbridos mostrou-se superior a das variedades nos três locais, observando-se que foi no Areão onde alcançou as maiores médias para o caráter PE, enquanto que para PROD foram igualmente maiores no Areão e Caterpillar. $O$ comportamento da diferença entre as médias dos dois tipos de materiais avaliados $\left(\mathrm{S}_{\mathrm{o}} \mathrm{e}\right.$ $S_{1}$ ) mantiveram uma mesma tendência nos três locais, de modo que onde $S_{o}$ foi alto, $S_{1}$ também foi. Isso garante uma mesma proporção na diferença entre esses dois tipos de materiais quando for estimada a depressão por endogamia em unidades do caráter (D.E.= $\mathrm{S}_{\mathrm{o}}-\mathrm{S}_{1}$ ). Assim sendo, as médias resultantes desses três locais têm caráter consistente, o 
que garante uma avaliação segura das análises de variância conjunta para esses caracteres.

Os valores encontrados para os coeficientes de variação experimental referentes aos resíduos (a), (b) e (c), foram equivalentes entre os três locais, tanto para PE quanto para PROD, sendo que entre esses dois caracteres a PROD foi a que apresentou os maiores valores de coeficiente da variação, o que já era esperado, por se tratar de um caráter muito mais influenciado pelo ambiente do que PE. Entretanto, os valores dos coeficientes de variação para PROD, foram razoáveis para esse caráter de acordo com referências encontradas na literatura (Gama et al., 1985; Nass, 1992; Terasawa Júnior, 1993). Os valores de coeficientes de variação para PE também encontram-se nos mesmos padrões encontrados por esses mesmos autores citados. $\mathrm{Na}$ análise conjunta os valores dos coeficientes de variação para os caracteres PE e PROD foram muito semelhantes aos das análises individuais, o que reforça a idéia de boa condução experimental. Portanto, conclui-se que os coeficientes de variação das análises de variância individual e conjunta apresentam valores considerados normais de acordo com cada caráter estudado indicando que a execução das avaliações transcorreram dentro de condições normais para o delineamento adotado (Tabelas 5 e 6).

Foi aplicado o teste de homocedasticidade dos quadrados médios dos erros (a), (b) e (c), para avaliar a possibilidade de reunião dos três ambientes em estudo e, conseqüentemente, realizar a análise de variância conjunta. Observa-se que, dentre todos os caracteres avaliados, os valores do quociente entre o maior e o menor quadrado médio do erro experimental para o erro (a) variaram entre 1,12 a 1,68, para o erro (b) variaram entre 1,36 a 4,85, e para o erro (c) variaram entre 1,10 a 2,13. Portanto, não havendo valores de grande magnitude as análises conjuntas foram normalmente realizadas, reunindo-se os três ambientes considerados para cada um dos caracteres em estudo.

Quanto a avaliação das análises conjuntas, observa-se alta significância $(P \leq 0,01)$ do efeito de locais para a maioria dos caracteres, com exceção de PROD, PE, $\mathrm{NE}$ e PROL, o que indica que os materiais genéticos foram avaliados sob condições 
ambientais distintas. Isso já era esperado, uma vez que os três locais apresentam características bem diferentes quanto ao tipo de solo e fertilidade (Tabelas 7 a 9).

Para o efeito de cultivares foi detectada alta significância $(\mathrm{P} \leq 0,01)$ para todos os caracteres avaliados, o que permite inferir que há diferença entre os materiais genéticos estudados. A seguir tem-se a decomposição desse efeito em grupos de acordo com o tipo de material. Para a variação dentro do grupo de híbridos, o teste $\mathrm{F}$ mostrou alta significância $(\mathrm{P} \leq 0,01)$ para todos os caracteres. Dentro do grupo das variedades houve alta significância $(\mathrm{P} \leq 0,01)$ para a maioria dos caracteres, com exceção de ES e PROD. Na comparação de Híbridos vs Variedades observou-se alta significância para a maioria dos caracteres $(P \leq 0,01)$, significância de $P \leq 0,05$ apenas para $P R O D$, e não significância para os caracteres NGF e PROF. Isso comprova a existência da diferença entre híbridos e as variedades quanto à maioria das características avaliadas (Tabelas 7 a 9). Tais resultados são concordantes aos de Gama et al. (1985) quanto a avaliação entre um grupo formado de híbridos simples, triplos e duplos e um grupo formado de híbridos intervarietais.

Dentro do efeito de Híbridos observa-se alta significância $(\mathrm{P} \leq 0,01)$ dentro do subgrupo HS para a maioria dos caracteres, sendo encontrada significância $\mathrm{P} \leq$ 0,05 para NGF , e não significância para AP e AE. Isso indica haver diferença entre os híbridos simples empregados no presente trabalho experimental, o que já era de esperar, uma vez que se tratam de híbridos comerciais de diferentes companhias e, portanto, devem apresentar constituição genética diferente. Semelhantemente, para o subgrupo HT foi constatada diferença altamente significativa $(P \leq 0,01)$ para a maioria dos caracteres, sendo observado $\mathrm{P} \leq 0,05$ para AP , exceção somente para o caráter AE. Para o subgrupo HD houve alta significância $(\mathrm{P} \leq 0,01)$ para a todos os caracteres, sendo observado significância $(P \leq 0,05)$ apenas para NGF. Nesses casos, tal como explicado para o subgrupo HS, a significância indica haver diferença entre os materiais pela mesma razão já comentada. 
Das comparações feitas entre os subgrupos HS, HT e HD, observou-se que o contraste HS vs HT apresentou significância $(\mathrm{P} \leq 0,05)$ para $\mathrm{DE}, \mathrm{AP}$ e $\mathrm{AE}$, alta significância $(P \leq 0,01)$ para $\mathrm{DS}, \mathrm{NF}$ e PRE, e não significância para PROD, $\mathrm{PE}, \mathrm{NE}$, PROL, $\mathrm{PG}_{500}, \mathrm{CE}, \mathrm{NGF}$, PROF e ES. Na comparação entre HS vs $\mathrm{HD}$, observou-se significância $(P \leq 0,05)$ para $C E, A E$ e $P R E$, e alta significância $(P \leq 0,01)$ para $P R O D$, PE, NE, PROL, $\mathrm{PG}_{500}, \mathrm{DE}, \mathrm{DS}, \mathrm{NF}, \mathrm{PROF}$ e AP, e não significância para NGF e ES. Como já se sabe, os híbridos simples são materiais mais vigorosos que os triplos e duplos, por isso já era de se esperar um comportamento diferenciado para aqueles caracteres. $\mathbf{O}$ caráter NGF não foi significativo na comparação de HS com os demais subgrupos, o que pode ser explicado pelo fato deste caráter tender a se manter constante, independentemente do material genético. Comparando-se os subgrupos HT e HD através do contraste $\mathrm{HT}$ vs $\mathrm{HD}$, nota-se diferença significativa $(\mathrm{P} \leq 0,05)$ para $\mathrm{NF}$, NGF e alta diferença significativa $(\mathrm{P} \leq 0,01)$ para $\mathrm{PROD}, \mathrm{PE}, \mathrm{NE}, \mathrm{PROL}, \mathrm{PG}_{500}, \mathrm{DE}$ e $\mathrm{DS}$, não havendo significância para CE, PROF, ES, ẢP, AE e PRE. Observando-se as médias de $S_{0}+S_{1}$ para todas as comparações entre os três subgrupos de híbridos (Tabela 10), verifica-se que as médias dos HS foram inferiores as dos demais subgrupos para a maioria dos caracteres que foram significativos. Isso pode ser explicado pelo fato desse subgrupo ser composto de poucos materiais genéticos, apenas três, o que possivelmente tenha prejudicado a análise para esse subgrupo.

No grupo VAR detectou-se alta significância $(P \leq 0,01)$ dentro do subgrupo de base genética ampla (BGA) para os caracteres $P E, \mathrm{PG}_{500}, \mathrm{DE}, \mathrm{DS}, \mathrm{NF}, \mathrm{CE}$,

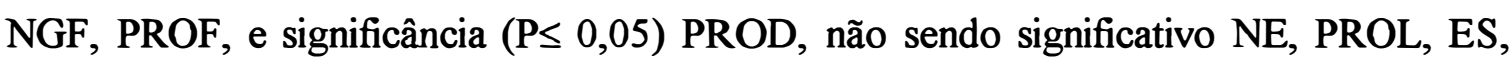
AP, AE e PRE. Dentre os materiais que compõem o subgrupo das variedades sintéticas (SINT) houve significância $(P \leq 0,05)$ para $P E$, e alta significância $(P \leq 0,01)$ para $N E$, PROL, PG ${ }_{500}$, DE, DS, NF, CE, NGF, PROF, e não significância para PROD, ES, AP, AE, PRE. Cabe ressaltar que a significância observada dentro desses subgrupos indica diferença entre os materiais genéticos, o que pode ser explicada em razão de possuírem constituição genética diferente. Finalmente, na comparação entre BGA vs SINT observase alta significância $(P \leq 0,01)$ para $\mathrm{DE}, \mathrm{CE}, \mathrm{PROF}, \mathrm{AP}$ e PRE e não significância para os 
demais caracteres. Isso indica que estes dois subgrupos são semelhantes para caracteres agronômicos importantes como PROD, PROL, PG $_{500}$ e NE.

$\mathrm{Na}$ interação Cultivares $\mathrm{x}$ Locais não foi detectada significância para os caracteres DE, DS, NF, NGF, PROF e AP, o que indica que o comportamento médio dos genótipos foi constante nos três locais, ou seja, em média os genótipos que foram superiores ou inferiores em um determinado local, mantiveram esse padrão nos demais locais. Por outro lado, essa fonte de variação foi significativa $(P \leq 0,05)$ para $P R O D$, $\mathrm{PG}_{500}$ e $\mathrm{AE}$, e altamente significativa $(\mathrm{P} \leq 0,01)$ para $\mathrm{CE}, \mathrm{PE}, \mathrm{NE}, \mathrm{PROL}, \mathrm{ES}, \mathrm{PRE}$, o que indica haver respostas diferenciadas de alguns genótipos em relação aos outros quanto às variações do local para esses caracteres.

$O$ efeito Tipos de materiais, que avalia o contraste $S_{o}$ vs $S_{1}$, foi altamente significativo $(\mathrm{P} \leq 0,01)$ para quase todos os caracteres, com exceção de PRE. Isso mostra que as médias dos materiais não endogâmicos $\left(S_{0}\right)$ diferiram significativamente dos endogâmicos $\left(\mathrm{S}_{1}\right)$, para a maioria dos materiais avaliados. Sabendo que as médias de $S_{1}$ foram, de modo geral, inferiores as médias de $S_{0}$, essa significância confirma a presença da depressão por endogamia decorrente da autofecundação.

A interação entre Tipos de materiais $\mathrm{x}$ Locais foi altamente significativa $(\mathrm{P} \leq 0,01)$ para $\mathrm{PROD}, \mathrm{PE}, \mathrm{NE}, \mathrm{PROL}, \mathrm{PG}_{500}, \mathrm{CE}, \mathrm{NGF}, \mathrm{ES}$ e AP e significativa $(\mathrm{P} \leq 0,05)$ para DE e PROF. Isso indica que o efeito médio da depressão por endogamia não foi consistente nos três locais de estudo, ou seja, a depressão por endogamia média dos materiais variou de um local para outro. Por outro lado, esse efeito foi não significativo para DS, NF, AE e PRE, o que indica que a depressão por endogamia média foi consistente nos três locais.

A interação Cultivares $\mathrm{x}$ Tipos de materiais foi altamente significativo $(\mathrm{P} \leq 0,01)$ para a maioria dos caracteres, com exceção de $\mathrm{AE}$ e PRE que foram não significativos. Isto indica que a diferença entre $S_{0}$ e $S_{1}$, isto é, a depressão por endogamia, variou de acordo com o material considerado. Esse comportamento diferenciado dos materiais em relação a depressão por endogamia já era esperado, uma vez que os materiais que compõem os grupos e subgrupos avaliados possuem origens diferentes. 
Quanto à interação tripla Locais $\mathrm{x}$ Cultivares $\mathrm{x}$ Tipos de materiais, somente os caracteres PROD, PE e PRE foram altamente significativos $(\mathrm{P} \leq 0,01)$. Inferese desse modo que, dependendo do local, a interação Cultivares $\mathrm{x}$ Tipos de materiais foi diferente. Essa significância para os caracteres PROD e PE pode ser facilmente explicada pela grande influência que o ambiente apresenta sobre tais caracteres, os quais são governados por muitos genes.

\subsection{Depressão por endogamia}

A seguir serão comentados os valores médios das populações originais $\left(\mathrm{S}_{0}\right)$ e das populações com uma geração de autofecundação $\left(\mathrm{S}_{1}\right)$, além das estimativas da depressão por endogamia expressas em porcentagem (D.E.\%) para todos os caracteres avaliados, bem como para cada um dos genótipos estudados, e dos grupos que compõem (Tabelas 11 a 25).

Nota-se que a depressão por endogamia variou não só em função do material (tipo de híbrido ou de variedade), como também da natureza do caráter em estudo; natureza essa, relacionada ao grau de complexidade genética do caráter (Tabelas 11 a 25). Pode-se observar também que, de modo geral, as médias dos materiais $S_{1}$ foram inferiores às dos materiais $\mathrm{S}_{0}$ para a maioria dos caracteres, o que já era esperado, uma vez que foi constatada alta significância $(\mathrm{P} \leq 0,01)$ para o efeito de Tipos de materiais $\left(\mathrm{S}_{0}\right.$ vs $S_{1}$ ) nas análises da variância para todos os caracteres, com exceção de PRE. Estes decréscimos já eram esperados devido aos efeitos depressivos causados pela endogamia, que é uma função de dois fatores: redução da heterozigosidade em locos que apresentam dominância gênica (Falconer, 1989) e da exposição de alelos recessivos desfavoráveis presentes na condição heterozigótica no conjunto gênico da população (Stebbins, 1957; 
Vencovsky \& Barriga, 1992). Assim sendo, maiores depressões são esperadas em caracteres controlados por maior número de fatores dominantes; em populações com elevada freqüência de heterozigotos em locos com dominância gênica, como no caso de híbridos simples, e em populações que apresentem acentuada carga genética, como por exemplo, populações não melhoradas (Falconer, 1989). Nesse trabalho foi verificado que as maiores depressões ocorreram para os caracteres PE e PROD, os quais são caracteres complexos, controlados por muitos locos. Além disso, observou-se que o grupo dos híbridos foi o que apresentou maior depressão por endogamia, o que pode ser explicado pelo fato desse grupo apresentar alto nível de heterozigose para esses caracteres em questão.

Para o caráter peso de espigas despalhadas (PE), foram encontrados valores médios da depressão por endogamia de $41,66 \%, 42,46 \%, 44,79 \%$ e $36,81 \%$ para os subgrupos HS, HT, HD e grupo das variedades, respectivamente. Pode-se notar que esses valores são muito próximos, especialmente entre os subgrupos dos híbridos, o que indica uma depressão por endogamia consistente para esse caráter (Tabela 11). O valor de depressão por endogamia para o grupo das variedades $(36,81 \%)$ está concordante com os valores obtidos por Mota (1974) e Mauro (1990), que foram 34,27\% e 32,60\%, respectivamente. Entretanto, são inferiores aos encontrados por Silva \& Pinto (1982), que trabalhando com seis variedades de milho Opaco 2 observaram valores em tomo de $51,7 \%$, e também inferiores aos valores obtidos por Nass (1992) para populações semiexóticas EE1 (ESALQ-PB1 x Entrelaçado 1) e EC4 (ESALQ-PB1 x Cravo 4), que foi cerca de $44,9 \%$.

Para produção de grãos (PROD), os valores médios encontrados foram de $35,06 \%, 35,91 \%, 41,17 \%$ e $32,42 \%$ para os subgrupos $\mathrm{HS}, \mathrm{HT}$, HD e grupo das variedades, respectivamente. Constata-se que esse caráter apresentou depressão por endogamia quase tão elevada quanto a depressão observada para PE. Deve-se ressaltar que tanto PE quanto PROD são caracteres complexos, governados por muitos locos gênicos, além de serem muito afetados pelo ambiente. As maiores reduções para PROD foram registradas no subgrupo $\mathrm{HD}$, seguido de $\mathrm{HT}$, $\mathrm{HS}$ e grupo das variedades 
(Tabela 12). O valor de depressão por endogamia verificado para HS no presente trabalho $(35,06 \%)$ foi concordante com os resultados de Gama et al.(1985), que encontraram valores em torno de 34,2\%. Entretanto, esses mesmos autores encontraram valores de depressão por endogamia de $26,4 \%$ e $32,35 \%$ para materiais híbridos triplos e duplos, respectivamente. Portanto, verifica-se que esses valores são inferiores aos obtidos nesse trabalho. A depressão por endogamia observada para o grupo das variedades $(32,42 \%)$ são concordantes com diversos trabalhos relatados na literatura. Mota (1974) estudando a variedade Centralmex observou que a depressão por endogamia de 36,68\% para a produção de grãos. Morera (1989) examinando os efeitos da depressão por endogamia em variedades sintéticas encontrou valores de 30,23\% a 36,17\% para produção de grãos. Mauro (1990) avaliando um material Composto Dentado encontrou depressão de 35,21\% para a produção de grãos. Hallauer \& Sears (1973) avaliando a depressão por endogamia da produção de grãos na variedade sintética "Iowa Stiff Stalk Synthetic" (BSSS) encontraram o valor médio de 31,28\%. Walters et al.(1991) também realizando avaliações da depressão por endogamia na variedade sintética "Iowa Staff Stalk Synthetic", encontraram valores em torno de 34,47\%. Lima et al. (1984) estudando 32 populações brasileiras observaram variações entre $27,0 \%$ a 59,9\%. Entretanto, outros trabalhos na literatura apontam para uma depressão por endogamia maior do que foi encontrada no presente trabalho. Geraldi \& Vencovsky (1980) reportam valores de $36,7 \%$ a 54,8\% na depressão para produção de nove populações brasileiras. Para Valois \& Miranda Filho (1984) este valor foi da ordem de 39,0\%. Vianna et al. (1982) constataram valores de depressão variando de $42,0 \%$ a $58,0 \%$ para 14 populações introduzidas. Neste último trabalho deve-se lembrar que os autores verificaram também que as populações derivadas de linhagens endogâmicas apresentaram valor médio de depressão de $34,0 \%$, enquanto que compostos e variedades de polinização livre tiveram o valor médio de $41,3 \%$. Nass (1992) avaliando a depressão por endogamia em populações semi-exóticas de milho EE1 (ESALQ-PB1 x Entrelaçado 1) e EC4 (ESALQ PB1 x Cravo 4) encontrou valores de 46,2\% e 46,7\%, respectivamente. Terasawa Júnior (1993) avaliando as populações ESALQ PB2- $C_{3}$ e ESALQ PB3- $C_{3}$ encontrou 
depressão por endogamia de 40,0\% e 44,0\%, respectivamente. Silva \& Pinto (1982) avaliando a depressão por endogamia em seis variedades de milho opaco-2 encontraram depressão por endogamia de 55,4 \% para a produção de grãos. Eagles \& Hardacre (1993) observaram a depressão por endogamia variando de 48,2\% a 65,3\% em cinco variedades sintéticas para o caráter produção de grãos. Esses autores relataram que a elevada depressão por endogamia apresentada por algumas das variedades foi devida a presença de genes deletérios recessivos.

Os caracteres PE e PROD foram os que apresentaram maior depressão em conseqüência da endogamia. A média da depressão por endogamia para esses dois caracteres foi acima de 36,81\% para PE e acima de 32,42\% para PROD (Tabelas 11 e 12). Esses resultados já eram esperados, pois conforme verificado na revisão de literatura, os caracteres que apresentam maior grau de dominância são os que apresentam os maiores valores de depressão por endogamia (Hallauer \& Miranda Filho, 1988; Souza Júnior \& Fernandes, 1997). Como já comentado, a autofecundação artificial provocada nos híbridos e variedades deste trabalho provocou a quebra da combinação gênica ideal para esses caracteres, o que resultou na grande redução da média desses caracteres. Falconer (1989) relata que a média de materiais submetidos à cruzamentos endógamos reduz numa proporção de $-2 \mathrm{~F} \Sigma$ pqd, portanto, é de se esperar que caracteres com maior nível de dominância (d) apresentem maior diminuição do valor da média.

Para o caráter peso de 500 grãos $\left(\mathrm{PG}_{500}\right)$ os valores médios foram de $23,58 \%, 14,99 \%, 13,97 \%$ e $8,04 \%$ para os subgrupos $\mathrm{HS}, \mathrm{HT}$, HD e grupo das variedades, respectivamente. Nota-se que os maiores valores de depressão foram verificados para o grupo do híbridos, em especial para o subgrupo $\mathrm{HS}$, enquanto que o grupo das variedades apresentou baixa depressão (Tabela 13). Isso pode ser explicado em razão dos híbridos apresentarem alto nível de heterozigose para esse caráter, o que garante uma alta depressão por endogamia após uma geração de autofecundação em virtude da quebra da combinação gênica ideal. Para o grupo das variedades, pode-se inferir que apresentam baixa quantidade de genes desfavoráveis, o que deve ter causado essa baixa depressão por endogamia. $\mathrm{Na}$ literatura há poucos trabalhos referentes a 
avaliação da depressão por endogamia para esse caráter. Silva \& Pinto (1982) avaliando a depressão por endogamia em seis variedades de milho opaco-2 encontraram depressão por endogamia de $14,3 \%$ para $\mathrm{PG}_{500}$. Mota (1974) estudando a variedade Centralmex observou que a depressão por endogamia de 34,27\% para $\mathrm{PG}_{100}$. Walters et al.(1991) realizando avaliações da depressão por endogamia na variedade sintética "Iowa Staff Stalk Synthetic" encontraram valores de $7,69 \%$ para $\mathrm{PG}_{300}$. Portanto, o valor de depressão encontrado neste trabalho é concordante apenas com o valor encontrado por este último autor para o peso de 300 grãos.

O caráter altura da planta (AP) apresentou valores médios de depressão por endogamia $7,16 \%, 14,36 \%, 8,20 \%$ e $7,38 \%$ para os subgrupos $\mathrm{HS}, \mathrm{HT}$, HD e gnupo das variedades, respectivamente. Já para a altura da espiga (AE) esses valores foram de $5,26 \%, 9,84 \%, 7,86 \%$ e $7,65 \%$, respectivamente. Para a posição relativa da espiga (PRE), embora não tenha ocorrido depressão por endogamia, como constatado na análise da variância conjunta, os valores encontrados foram muito baixos, $0,28 \%, 1,45 \%$, $0,67 \%$ e $0,72 \%$, para os subgrupos $\mathrm{HS}, \mathrm{HT}, \mathrm{HD}$ e grupo das variedades, respectivamente. Deve-se observar que para o caráter AP o subgrupo HT apresentou alta depressão por endogamia, $14,36 \%$, enquanto que os demais materiais tiveram depressão variando entre $7,16 \%$ a $8,20 \%$. Semelhantemente, para o caráter $\mathrm{AE}$ a depressão por endogamia foi maior também no subgrupo HT, 9,84\%, enquanto que os demais materiais apresentaram depressão entre $5,26 \%$ a 7,86\%. Uma possível razão do subgrupo HT apresentar maior depressão por endogamia para $\mathrm{AP}$ e $\mathrm{AE}$ que os demais materiais é a de que possuem um alto nivel de heterozigose para os locos que controlam ambos os caracteres. A ausência de depressão por endogamia para o índice PRE deve-se à ocorrência de uma estabilidade na diferença entre as médias de $S_{o}$ e $S_{1}$, isto é, os diferentes materiais sofreram uma intensidade de depressão para $\mathrm{AE}$ da mesma magnitude que para AP (Tabelas 14, 15 e 16).

No estudo detalhado feito por Gama et al. (1985) sobre depressão por endogamia em quatro tipos genéticos de híbridos de milho, os valores de depressão para AP foram de $9,41 \%, 10,10 \%, 8,20 \%$ e $12,04 \%$ para híbridos simples, triplos, duplos e 
intervarietais, respectivamente. Para o caráter $\mathrm{AE}$ os valores foram de $11,6 \%, 12,19 \%$, $11,37 \%$ e 13,13\%, respectivamente. Esses valores são concordantes aos obtidos para os materiais híbridos deste trabalho, sendo superiores ao valor da depressão das variedades. Os valores da depressão por endogamia das variedades neste trabalho tanto para AP como para AE estão próximos aos obtidos por Terasawa Júnior (1993), que encontrou valores de depressão por endogamia nas populações ESALQ-PB 2 C3 e ESALQ-PB3 C3: $8,1 \%$ e $8,0 \%$ (AP) e $8,9 \%$ e $8,2 \%$ (AE). Não se deve esquecer que estas populações foram submetidas a três ciclos de seleção recorrente com endogamia e, portanto, apresentam menor carga genética. Mota (1974) estudando a variedade Centralmex encontrou valores de depressão por endogamia de 9,32\% para AE. Walters et al.(1991) realizando avaliações da depressão por endogamia na variedade sintética "Iowa Staff Stalk Synthetic" encontraram valores de 9,76\% para AP. Entretanto, outros autores encontraram valores de depressão por endogamia maiores dos que observados para as variedades neste trabalho. Silva \& Pinto (1982) encontraram valores médios de depressão por endogamia de $16,2 \%$ e 15,6\% para AP e AE, respectivamente, em estudos de seis variedades de milho Opaco2. Estudos de Hallauer \& Sears (1983) na variedade sintética de milho BSSS revelaram depressões de $12,75 \%$ e $16,84 \%$, para AP e AE, respectivamente. Lima et al. (1984) relatam depressões médias de 14,0\% (variando entre $6,6 \%$ a $20,3 \%$ ) para AP e $15,4 \%$ (variando entre $6,9 \%$ a $27,4 \%$ ) para AE. Nass (1992) reportou valores de depressão por endogamia de $13,7 \%$ e $12,8 \%$ (AP) e de $15,9 \%$ e 14,2\% (AE) para as populações semi-exóticas EE1 (ESALQ-PB1 x Entrelaçado 1) e EC4 (ESALQ-PB1 x Cravo 4), respectivamente. Mota (1974) estudando a variedade Centralmex encontrou valores de depressão por endogamia de 15,41\% para AP. Mauro (1990) avaliando um material Composto Dentado encontrou valores depressivos de $19,20 \%$ para AP e $24,86 \%$ para altura da espiga. Walters et al.(1991) realizando avaliações da depressão por endogamia na variedade sintética "Iowa Staff Stalk Synthetic" encontraram valor de $12,02 \%$ para $\mathrm{AE}$.

Quanto ao índice PRE, alguns autores observaram baixos valores de depressão por endogamia tal como foi observado no presente trabalho. Pelos dados do 
trabalho de Nass (1992) calcula-se valores variando de 0,4 e 0,5\%, e Silva (1988) de $0,2 \%$. Tais resultados confirmam aparente ausência de depressão por endogamia para este índice.

Para o caráter número de espigas da parcela (NE) os valores de depressão por endogamia foram $8,50 \%, 15,99 \%, 19,79 \%$ e $17,48 \%$, para os subgrupos HS, HT, HD e grupo das variedades, respectivamente (Tabela 17). Para prolificidade (PROL) foram de 10,07\%, 15,94\%, 20,53\% e 17,27\%, respectivamente (Tabela 18). Para o estande (ES) os valores médios de depressão por endogamia foram de 4,96\%, $4,82 \%, 6,02 \%$ e $8,43 \%$, respectivamente (Tabela 19). O caráter prolificidade é sem dúvida um dos mais importantes do ponto de vista agronômico, pois tem relação direta com a produção. Nota-se que a variação da depressão por endogamia para a prolificidade foi alta dentro do grupo dos híbridos, tendo variado de $10,07 \%$ a 20,53\%. Observa-se que a depressão em HD foi o dobro que em HS. Nota-se, também, que a depressão por endogamia nas variedades foi quase tão alta quanto em HD. Avaliações de Gama et al. (1985) sobre a depressão por endogamia no caráter prolificidade em híbridos simples, triplos, duplos e intervarietais mostraram valores 6,30\%, 1,37\%, 2,23\% e 9,16\%, respectivamente. Walters et al. (1991) encontraram o valor de depressão $11,11 \%$ para prolificidade na variedade sintética "Iowa Staff Stalk Synthetic". Verifica-se, portanto, que todos os valores citados estão abaixo dos valores encontrados no presente trabalho, especialmente para os materiais híbridos.

Quanto aos caracteres relacionados à espiga os valores médios de depressão por endogamia não foram tão altos como os verificados em caracteres anteriores. $\mathrm{O}$ caráter diâmetro da espiga (DE) apresentou valores de depressão por endogamia de $8,44 \%, 5,75 \%, 6,07 \%$ e $5,86 \%$, para os subgrupos HS, HT, HD e grupo das variedades, respectivamente (Tabela 20). Para o diâmetro do sabugo (DS) os valores de depressão foram: 3,59\%,2,09\%, 2,56\% e 0,78\%, respectivamente (Tabela 21). Para o número de fileiras de grãos (NF) os valores foram de 2,16\%, 0,56\%, 2,80\% e 1,61\%, respectivamente (Tabela 22). Para o número de grãos por fileira (NGF) os valores foram de $7,43 \%, 12,36 \%, 15,51 \%$ e $10,77 \%$, respectivamente (Tabela 23 ). Para o comprimento 
da espiga (CE) 4,69\%, 7,66\%, 10,62\% e 6,76\%, respectivamente (Tabela 24). Nota-se, que os caracteres NF e DS apresentaram depressões muito baixas, variando de $0,56 \%$ a $3,59 \%$. A menor depressão em DS foi verificada nas variedades $(0,78 \%)$, enquanto que nos híbridos variou de 2,09\% a 3,59\%. Para o NF a menor depressão foi em HT $(0,56 \%)$, seguido as variedades $(1,61 \%)$. Os caracteres NF e DS, portanto, foram os que apresentaram os menores valores de depressão por endogamia entre todos os caracteres avaliados no presente trabalho. Na literatura há referências de valores pouco acima desses. Hallauer \& Sears (1973) avaliando a variedade sintética "Iowa Stiff Stalk Synthetic" encontraram valor de 3,69\% para DS. Quanto ao caráter NF, Mota (1974) observou depressão de 3,65\% na variedade Centralmex, e Walters et al.(1991) obtiveram valor de 4,10\% na variedade sintética "Iowa Staff Stalk Synthetic". Para os caracteres NGF e CE as menores depressões foram em HS (7,43\% e 4,69\%, respectivamente), e as maiores em $\mathrm{HD}(15,51 \%$ e $10,62 \%$, respectivamente), enquanto que as variedades apresentaram depressão intermediária $(10,77 \%$ e $6,76 \%$, respectivamente). Para DE a depressão foi maior em HS (8,44\%), apresentando valores muito próximos nos para os demais subgrupos de materiais (5,75\% a 6,07\%). Os valores de depressão por endogamia das variedades para os caracteres NGF, CE e DE estão abaixo dos encontrados na literatura. Mota (1974) avaliando a variedade Centralmex obteve depressão por endogamia de $15,41 \%$ para NGF, cerca de $9,32 \%$ para CE e DE. Hallauer \& Sears (1973) avaliando a depressão por endogamia na variedade sintética "Iowa Stiff Stalk Synthetic" encontraram valores de 8,67\% para CE e 8,13\% para DE. Walters et al.(1991) também avaliando a variedade sintética "Iowa Staff Stalk Synthetic", observaram depressão de $18,04 \%$ para CE e 6,81\% para DE.

O caráter profundidade do grão (PROF) apresentou depressão por endogamia de $15,70 \%, 11,70 \%, 14,49 \%$ e $13,47 \%$, para os subgrupos HS, HT, HD e grupo das variedades, respectivamente (Tabela 25). O valor da depressão para as variedades está concordante com o valor obtido por Hallauer \& Sears (1973), que foi de $12,95 \%$ na variedade sintética "Iowa Stiff Stalk Synthetic". Entretanto, Walters et al. 
(1991) também avaliando a variedade sintética "Iowa Staff Stalk Synthetic", não encontraram depressão para esse caráter.

Observa-se, portanto, que para muitos caracteres a depressão por endogamia variou muito em relação aos valores encontrados na literatura. Isso já era esperado, uma vez que se sabe que a depressão por endogamia é variável de acordo com o material em estudo e sua constituição genética (populações melhoradas, híbridos com alto nivel de heterozigose) (Hallauer \& Miranda Filho, 1988).

Deve-se ressaltar que para os caracteres com alta herdabilidade e menor grau de dominância, como $\mathrm{CE}, \mathrm{DE}, \mathrm{DS}, \mathrm{AP}, \mathrm{AE}$, dentre outros (Hallauer \& Miranda Filho, 1988) foram verificados menores valores de depressão por endogamia do que para a produção de grãos (PROD) e peso de espigas despalhadas (PE), que apresentam baixa herdabilidade e maior grau de dominância. Fato esse já esperado, uma vez que se tem conhecimento de que a depressão por endogamia é diretamente proporcional ao nível de dominância do caráter (Hallauer \& Miranda Filho, 1988; Souza Júnior \& Fernandes, 1997).

Verifica-se que, dos subgrupos de híbridos e grupo das variedades estudados, os efeitos de depressão por endogamia foram mais pronunciados, para a maioria dos caracteres, nos subgrupos HS e HD. Essa constatação pode indicar a possibilidade de alto grau de heterozigose, o que evidencia uma maior divergência entre as linhagens que entraram na formação destes subgrupos.

Uma importante observação a ser feita é que, de modo geral, as médias dos materiais $S_{1}$ foram inferiores às dos materiais $S_{0}$, decréscimos estes já esperados, devido aos efeitos depressivos causados pela endogamia. Porém, em alguns materiais e para determinados caracteres, as médias de $S_{1}$ foram superiores as de $S_{0}$, o que resultou numa depressão por endogamia negativa. Por exemplo, XL 510 para ES (-3,78\%), C 425 para DE $(-4,23 \%)$, XL 520 para DS $(-8,09 \%)$ e para NF $(-3,69 \%)$, XL 560 para NF $(-2,14 \%)$ e IG-2 para NF $(-3,52 \%)$. Tais valores negativos podem ser explicados pela associação de dois fatores: valores superiores a média populacional, para algumas plantas $S_{0}$ das quais se extrairam os materiais $S_{1}$; segregação de plantas não endógamas 
heterozigotas $\left(\mathrm{S}_{0}\right)$, resultando em materiais $\mathrm{S}_{1}$ que concentrem fatores dominantes positivos para a expressão do caráter. Esta segunda hipótese é mais viável de ser explicada em caracteres com baixo grau de dominância, como AP e AE, por exemplo, quando avaliados um número muito restrito de plantas $S_{1}$ por planta $S_{0}$ original. De fato, considerando-se um caráter sem dominância em uma população com ausência total de genes letais e/ou deletérios a média esperada dos materiais $S_{1}$ é igual à média populacional $\left(\mathrm{S}_{0}\right)$ e, sob uma distribuição teórica simétrica, $50 \%$ dos materiais $\mathrm{S}_{1}$ seriam superiores à média populacional.

\subsection{Estudo dos componentes $(\mu+$ a) e (d)}

Numa observação mais detalhada das médias de $S_{0}$ e $S_{1}$, além da depressão por endogamia, procedeu-se o estudo da contribuição dos homozigotos $(\mu+a)$ e dos heterozigotos (d), as quais permitem extrair informações importantes sobre o material. Os valores dessas contribuições para cada material, bem como para cada subgrupo e grupo, em cada um dos caracteres avaliados serão discutidos a seguir (Tabelas 11 a 25).

De todos os caracteres estudados apenas PE e PROD tiveram a contribuição dos heterozigotos superior a dos homozigotos (Tabelas 11 e 12). Segundo Lima et al. (1984) um modelo simples sem epistasia, onde a contribuição de ambos os homozigotos para a média é positiva, espera-se que os valores de $(\mu+a)$ sejam superiores aos valores de (d) para caracteres com elevado nível de dominância. Desta forma, valores altos de $(\mu+a)$ são indicativos do potencial dos materiais como fonte de linhagens com alta produção. Os resultados observados para PE e PROD, portanto, confirmam a natureza desses caracteres (elevado grau de dominância). Nass \& Miranda Filho (1995) relatam que os valores baixos de $(\mu+$ a) para as populações EE1 e EC4 
sejam decorrentes da presença de genes deletérios nelas, o que as inviabilize como fonte de linhagens. Entretanto, esses autores afirmam que autofecundações contínuas para obter linhagens endogâmicas podem diminuir a quantidade de genes deletérios nessas populações e melhorar caracteres de interesse agronômico. Além disso, contínuas autofecundações e seleções podem permitir obter linhagens com melhores performances que as indicadas pelos valores baixos de $(\mu+\mathrm{a})$.

Os valores de $(\mu+a)$ no presente trabalho para o caráter PROD foram de: 4210,85 , 2834,51 , 2257,86 e 2576,73 para os subgrupos HS, HT, HD e grupo das variedades, respectivamente. Os valores de (d) foram: 5702,21 , 5845,09, 6337,63 e 4750,16 para os subgrupos HS, HT, HD e grupo das variedades, respectivamente. A literatura relata diversos trabalhos que mostram que o valor de (d) é muito superior ao de $(\mu+a)$, e que confirmam os resultados do presente trabalho. Lima et al. (1984) avaliando 32 populações brasileiras encontraram valor de 1120,00 para $(\mu+\mathrm{a})$, e 5180,00 para (d). Nass (1992) encontrou os valores de $(\mu+$ a) de 468,00 e 612,00, e os valores de (d) encontrados foram de 5808,00 e 8808,00 , para as populações semi-exóticas de milho EE1 e EC4, respectivamente. Terasawa Júnior (1993) obteve os valores de $(\mu+a)$ de 1220,00 e 960,00 , e de (d) foram de 4606,67 e 4393,32, para as populações de milho ESALQ PB- $2 \mathrm{C}_{3}$ e ESALQ PB- $3 \mathrm{C}_{3}$, respectivamente. Vianna et al. (1982) no estudo de 14 populações de milho introduzidas no Brasil, obtiveram estimativas que variaram entre -480 a 250 para $(\mu+$ a) e entre 1360 a 3530 para (d). Apesar de alguns valores citados serem bem diferentes dos encontrados neste trabalho, eles indicam o caráter dominante da produção de grãos.

Com respeito ainda aos caracteres PROD e PE observa-se que dentro do grupo dos híbridos, o subgrupo HS mostrou ter maiores valores de $(\mu+a)$, seguido de HT e depois HD. Das variedades, os materiais HS-1 e HS-2, que são populações $F_{2}$ de híbridos simples, foram os que tiveram maiores valores de $(\mu+a)$ sobre $(d)$, além disso esses valores foram os maiores quando comparados aos valores de todos os demais materiais estudados. A princípio esses parecem ser os materiais mais promissores como fonte de linhagens em razão de apresentarem valores elevados de $(\mu+a)$, entretanto, 
deve-se ressaltar que as estimativas de $(\mu+$ a) e (d) para esses materiais, não são corretas em virtude desses materiais já apresentarem certo nível de endogamia.

Como já era esperado, os valores da relação $(\mu+a) /(d)$ para os caracteres PE e PROD também foram os menores de todos os caracteres avaliados. Para PE os valores médios dos grupos foram $0,48,0,28,0,35$ e 0,47 , para os materiais $\mathrm{HS}$, HT, HD e variedades, respectivamente. Para PROD foram 1,08, 0,55, 0,52 e 0,67, respectivamente. $\mathrm{O}$ valor obtido para PROD no grupo de variedade está acima do valor médio encontrado por Lima et al. (1984) em 32 populações brasileiras, que foi de 0,28. Tanto em PE como em PROD os maiores valores da relação $(\mu+a) /(d)$ foram observadas para o grupo das variedades, seguido de HD, HT e HS.

As estimativas da contribuição dos locos homozigotos $(\mu+a)$ e heterozigotos (d) confirmam a natureza predominantemente aditiva dos caracteres AP e AE (Tabelas 14 e 15). Para ambos caracteres, as estimativas obtidas de $(\mu+$ a) foram cerca de 5 vezes superiores aos valores encontrados de (d). Para o caráter AP os valores de $(\mu+$ a) apresentaram intervalo de variação das médias entre 141,17 a 174,83, e variação de 27,43 a 56,8 para (d). No caráter $\mathrm{AE}$ as médias variaram de 84,21 a 94,91 para $(\mu+a)$, e 1,30 a 20,64 para (d). Resultados esses concordantes com os encontrados por Lima et al. (1984) para AP, que foram de 172 e 71 para $(\mu+$ a) e (d), respectivamente, e para $A E$, de 105 e 47 para $(\mu+$ a) e $(d)$, respectivamente. Também foram concordantes com os valores de Lima et al.(1984), Nass (1992) e Terasawa Júnior (1993). Não foram verificadas diferenças significativas entre os valores de $(\mu+a)$ para os materiais estudados.

Para os caracteres NE e PROL, que estão relacionados diretamente com a produção, deve-se notar que o subgrupo HS apresentou o maior valor de $(\mu+a)$, HT apresentou o menor, e os materiais $\mathrm{HD}$ e as variedades apresentaram posição intermediária (Tabelas 17 e 18). Os valores médios da relação $(\mu+a) /(d)$ em ambos caracteres foram muito semelhantes para cada um dos subgrupos e grupo das variedades. Os valores médios para NE foram: $11,74,2,83,2,13$ e 1,76, para os subgrupos HS, HT, 
HD e grupo das variedades, respectivamente. Os valores médios para PROL foram: $12,53,2,99,2,05$ e 1,73, para os subgrupos HS, HT, HD e grupo das variedades, respectivamente. Deve-se ressaltar que o alto valor observado na média de $(\mu+\mathrm{a}) /(\mathrm{d})$ para HS tanto para NE como para PROL se deve ao fato de o material ZENECA 8392 apresentar baixa depressão por endogamia, o que ocasionou alto valor para $(\mu+a)$ e, conseqüentemente, alto valor para a relação $(\mu+a) /(d)$. O valor da relação $(\mu+a) /(d)$ para o material ZENECA 8392 foi de 29,81 em NE e 32,00 em PROL. Isso elevou a média do subgrupo HS.

Para o caráter ES os valores da relação $(\mu+$ a)/(d) foram de 9,89 , $15,45,11,87$ e 5,66 para os subgrupos HS, HT e HD e o grupo de variedades, respectivamente. Deve-se observar que os materiais hibridos apresentam valores próximos, enquanto que o grupo das variedades apresenta um valor bem menor (Tabela 19).

No caráter $\mathrm{PG}_{500}$ o grupo das variedades foi o que apresentou o maior valor da relação $(\mu+a) / d$, seguido de $H D$, HT e HS. Aqui nota-se que esta seqüência de contribuição dos homozigotos é igual aquela apresentada para os caracteres PE e PROD. Nesse caso, porém, os materiais que apresentaram maiores contribuições dos homozigotos foram: C 425 (HD), CMS-05 (VAR), HS-2(VAR) e HS-1 (VAR) (Tabela 12).

Para o caráter PROF os valores de $(\mu+a)$ foram semelhantes nos diferentes subgrupos e grupo das variedades avaliados (Tabela 25). Os valores médios da relação $(\mu+a) /(d)$ variaram de 2,98 a 4,20 .

$\mathrm{O}$ caráter DE apresentou valores de contribuição de homozigotos semelhantes entre todos os subgrupos e grupo de materiais avaliados. Os valores médios da relação $(\mu+a) /(d)$ variaram de 3,63 a 4,20 entre os híbridos, enquanto para o grupo das variedades ela foi menor $(2,98)$ (Tabela 20 ). Nota-se, portanto, que os valores estão muito próximos entre esses grupos materiais. $\mathrm{O}$ valor médio obtido para o grupo das variedades é próximo aos valores obtidos por Nass (1992) para as populações semiexóticas de milho EE1 e EC4, que foram de 1,91 e 3,03, respectivamente. 
Para os caracteres NGF e CE verifica-se que o subgrupo HS apresenta o maior valor de $(\mu+a)$, e HD o menor, enquanto HT e o grupo das variedades estão em posição intermediária. Os valores da relação $(\mu+a) /(d)$ também foram maiores para $H S$, menores em HD, e intermediários em HT e variedades. Para o caráter NGF os valores médios de $(\mu+\mathrm{a}) /(\mathrm{d})$ variaram entre 2,50 a 6,05 , e para CE variaram de 4,51 a 13,11 (Tabelas 23 e 24). Os valores médios obtidos para CE são inferiores aos obtidos por Nass (1992) para as populações semi-exóticas de milho EE1 e EC4, que foram de 1,68 e 2,16, respectivamente.

Dos caracteres em que a contribuição dos homozigotos supera a dos heterozigotos deve-se destacar PRE, DS e NF, onde se observa que a contribuição dos heterozigotos chegou a ser nula para alguns materiais. Isso indica haver uma contribuição quase que exclusivamente aditiva para esses caracteres. Além disso, deve-se ressaltar que os valores da relação $(\mu+a) /(d)$ foram muito altos e variáveis entre os materiais avaliados. Para PRE os valores médios de $(\mu+$ a)/(d) estão entre 39,75 a 47,00, para DS estão entre 13,36 a 43,41 e para NF estão entre 15,37 a 34,74 (Tabelas 16, 21 e 22).

De todos os caracteres até aqui discutidos, pôde-se observar que para os caracteres NE, PROL, CE e NGF, que são reconhecidamente de alta herdabilidade (Hallauer \& Miranda Filho, 1988; Paterniani, 1995; Tatis, 1990; Holthaus \& Lamkey, 1995), o subgrupo HS sempre teve os maiores valores de $(\mu+a) /(d)$ em relação aos demais subgrupos de híbridos, o que indica um forte caráter aditivo desses caracteres para esse subgrupo. Para os caracteres NE e PROL, os valores foram semelhantes entre HT, HD e variedades. Para os caracteres CE e NGF, os menores valores foram verificados para $\mathrm{HD}$, tendo $\mathrm{HT}$ e variedades uma posição intermediária. Uma vez que já se sabe que existe alto grau de heterozigose em materiais que sejam híbridos simples, seguido dos híbridos triplos e depois os híbridos duplos, enquanto que para as variedades espera-se muito pouca heterozigosidade, tais resultados mostraram que a magnitude da relação $(\mu+a) /(d)$ são concordantes com a natureza dos materiais avaliados.

Deve-se ressaltar que, com exceção de PE e PROD, todos os caracteres avaliados apresentam relação $(\mu+a) /(d)$ maior que 1,00. Enquanto, os 
caracteres $\mathrm{AP}, \mathrm{AE}, \mathrm{PG}_{500}, \mathrm{NE}, \mathrm{PROL}, \mathrm{ES}, \mathrm{DE}, \mathrm{NGF}, \mathrm{CE}$ e PROF apresentaram valores da relação $(\mu+a) /(d)$ entre cerca de 2,00 a 10,00, os caracteres PRE, DS e NF apresentaram valores muito acima de 10,00. Fica evidente, portanto, que a contribuição aditiva para os três últimos caracteres é muito grande.

Valores negativos de $(\mu+$ a) são observados em alguns materiais, para os caracteres PROD e PE (Tabelas 11 e 13), o que pode ser explicado, segundo Lima et al. (1984), como conseqüência de erro experimental ou devido a uma homozigosidade maior do que a proporção esperada (50\% para as linhagens $\left.S_{1}\right)$. Lima et al. (1984) complementam ainda que há possibilidade da ocorrência do efeito epistático de outros sistemas genéticos (outros pares de genes) sobre os genes controlando os caracteres em questão. Pinto et al. (1989) explicam a ocorrência desses valores negativos como fato de que uma super-estimação dos efeitos da endogamia, em razão da linearidade do modelo de Gardner e Eberhart (1966), sendo que o problema se agrava nas gerações mais avançadas, levando à obtenção de estimativas irreais (negativas) para linhagens.

Sabe-se que os alelos desfavoráveis (deletérios), prejudicam sensivelmente a produção de grãos, sendo que se manifestam na condição heterozigótica; sob o crivo de endogamia, tais alelos mostram-se em homozigose e interferem na produtividade, muitas vezes através de ação epistática. Conseqüentemente, para uma população com alta freqüência de genes favoráveis, que já tenha passado por processos endogâmicos, como as variedades sintéticas, tais estimativas são aceitáveis, pela menor expressão da carga genética. Em contrapartida, para populações que apresentam alta carga genética, com grande quantidade de genes desfavoráveis, tais alelos em homozigose influenciarão de maneira muito drástica e os resultados serão muito tendenciosos. Nass \& Miranda Filho (1995) relataram que a carga genética presente em variedades acarreta valores muito baixos do componente $(\mu+a)$, o que pode ser modificado através da diminuição dessa carga genética pelo melhoramento genético. Infere-se, portanto, que o modelo de Gardner e Eberhart (1966) é incompleto, sendo necessários estudos mais detalhados envolvendo avaliações sobre epistase para que o modelo se torne mais consistente. 
De maneira geral, ficou evidente a maior contribuição dos homozigotos para os caracteres PROD, PE e PG $_{500}$ no grupo das variedades. Considerando-se que os valores de $(\mu+a)$ estimam o desempenho médio de linhagens totalmente endogâmicas, espera-se que melhores linhagens sejam obtidas do grupo das variedades, onde os valores de $(\mu+$ a) foram maiores para PROD e PE. Ressalta-se, conforme já discutido, que a obtenção de linhagens vigorosas é de fundamental importância em programas de melhoramento, pois permite que a exploração da heterose não seja restringida pela inviabilidade de produção da semente híbrida.

\subsection{Componentes da produção de grãos}

Conforme a metodologia desenvolvida por Grafius (1960) os principais componentes da produção de grãos são: peso médio do grão $(\mathrm{Pg})$, número de espigas por parcela (NE), número de grãos por fileira (NGF) e número de fileiras de grãos (NF). As médias de tais componentes para todos os genótipos estudados, assim como para os grupos que os compõem, além dos dois tipos de materiais $\left(S_{0}\right.$ e $\left.S_{1}\right)$, encontram-se na Tabela 26. Vale lembrar que a produção de grãos é apresentada nessa tabela na sua forma estimada como produto de seus quatro componentes.

A Tabela 27 mostra a conversão para a escala logarítmica dos dados referentes à Tabela 26. A seguir os logaritmos dos componentes da produção de grãos foram expressos em porcentagem em relação ao logaritmo da produção de grãos estimada (Tabela 28). Os resultados obtidos nessa forma, permitem um melhor estudo comparativo não só entre os componentes da produção de grãos, mas também entre os grupos de genótipos quanto à participação de seus componentes na função de produção.

Para os valores porcentuais dos componentes referentes a população não endógama $\left(S_{0}\right)$ nota-se, com grande evidência, que a participação de cada um dos 
componentes da produção de grãos, ou seja, NE, Pg, NF e NGF, foi diferenciada independente do tipo de material (híbrido ou variedade), sendo que o componente Pg foi o que contribuiu mais para a produção de grãos, com média geral de $38,05 \%$, seguido do NGF $(23,88 \%)$, NE $(20,09 \%)$ e NF $(17,84 \%)$. Além disso, nota-se que as contribuições relativas de cada componente foram semelhantes entre os materiais, como por exemplo, a contribuição de Pg para a produção de grãos variou de $37,07 \%$ a $39,07 \%$, para NGF variou de $23,35 \%$ a $34,34 \%$, para NE variou de $16,55 \%$ a $20,88 \%$ e $\mathrm{NF}$ variou de $17,30 \%$ a $18,40 \%$. Verifica-se que no subgrupo HS a contribuição do NE foi baixa em relação aos demais grupos, o que pode ser explicado pelo fato de terem sido avaliados poucos materiais neste subgrupo, e o híbrido XL 212 ter apresentado valor porcentual de contribuição muito abaixo da média geral (Tabela 28 e Figura 1).

Tavares (1972) estudando os componentes da produção de grãos em seis populações de milho, encontrou para os componentes NGF, NF, NE e Pg as seguintes contribuições médias: $72,17 \%, 55,92 \%, 0,29 \%$ e $-28,39 \%$, respectivamente. Entretanto, deve-se ressaltar que este autor considerou, em suas medições, o número de espigas por planta e peso médio do grão em gramas por parcela, o que gerou valores de logaritmos menores que um e, também, valores negativos. Como no presente trabalho foram feitas medições do número de espigas por parcelas e o peso médio do grão considerado em miligramas, os valores expressos em porcentagem não se tornaram nem próximos a zero e nem a valores negativos, como se observa para os resultados de Tavares (1972). Assim sendo, observa-se uma grande diferença na magnitude da proporção da contribuição dos componentes da produção de grãos deste autor quando comparada aos resultados obtidos neste trabalho o que dificulta a sua comparação. Portanto, pode-se afirmar que essa metodologia apresenta a desvantagem de ser dependente da unidade de medida dos componentes da produção de grãos, o que dificulta a sua utilização.

Os resultados da participação dos componentes da produção de grãos referentes ao material $S_{1}$, semelhantemente ao observado para ao material $S_{0}$, indicaram que a participação de cada um dos componentes da produção também foi diferenciada 
independente do tipo de material (híbrido ou variedade), sendo que novamente o componente Pg foi o que contribuiu mais para a produção de grãos, com média geral de $38,30 \%$, seguido do NGF $(23,78 \%)$, NE (19,59\%) e NF (18,32\%). Nota-se, também, que as contribuições relativas de cada componentes novamente foram semelhantes em todos os materiais, como por exemplo, a contribuição de Pg para a produção de grãos variou de $37,41 \%$ a $39,25 \%$, para NGF variou de $23,32 \%$ a $24,76 \%$, para NE variou de $18,24 \%$ a $20,46 \%$ e NF variou de $17,60 \%$ a $19,40 \%$ (Tabela 28 e Figura 2 ).

Comparando-se os valores porcentuais de cada componente entre os materiais $S_{0}$ e $S_{1}$, nota-se que são muito semelhantes. Por exemplo, para Pg a média geral foi de $38,05 \%$ em $\mathrm{S}_{\mathrm{o}}$ e de $38,30 \%$ em $\mathrm{S}_{\mathrm{l}}$, e para NGF foi de $23,88 \%$ em $\mathrm{S}_{\mathrm{o}}$ e de $23,78 \%$ em $S_{1}$. Esses resultados indicam, que mesmo sob efeito da depressão por endogamia, a participação dos componentes da produção se manteve constante nos diferentes híbridos e variedades, e que o peso médio do grão continua sendo o principal componente da produção de grãos, sendo responsável por cerca de $38,0 \%$ desta, enquanto que os demais componentes, apresentam uma contribuição individual semelhante para a produção de grãos $(\cong 20,0 \%)$ (Tabela 28 e Figuras 1 e 2$)$. Tais informações são de grande valia para o melhoramento genético, pois uma vez que o componente peso médio do grão é tido como o principal responsável pela produção de grãos, ele pode ser um critério auxiliar de seleção em programas de melhoramento de seleção para produção.

Deve-se lembrar que a literatura indica haver média a alta herdabilidade do caráter peso de grãos contados, como por exemplo Vianna (1977) e Ribeiro (1990) para o peso de 50 grãos, Mauro (1990), Silveira (1990), Tatis (1990), Silva (1991) e Sawazaki (1996) para peso de 100 grãos e Paterniani (1995) para o peso de 500 grãos. Vale lembrar que o peso de grãos contados está diretamente associado ao peso médio de grãos, uma vez que o valor do peso médio do grão é a estimativa da razão entre o peso de grãos contados e o número de grãos a ele associado. Assim sendo, o peso médio do grão também deve apresentar média a alta herdabilidade. Além disso, o peso de grãos contados está positiva e significativamente correlacionado com a produção de grãos 
(Naspolini Filho, 1975; Vianna, 1977; Torres, 1978; Gomide, 1980; Cruz, 1983; Pereira, 1990; Ribeiro, 1990; Silveira, 1990; Silva, 1991). Tudo isso fortalece a idéia de que o peso médio do grão pode ser efetivamente utilizado como critério auxiliar de seleção para a produção de grãos.

Não se deve esquecer, entretanto, de que há referências de o componente peso de grãos contados ser negativo e significativamente correlacionado ao número de espigas (Vianna, 1977; Regazzi, 1978; Cruz, 1983; Mauro, 1990). Isso indica que uma seleção intensa para o componente peso médio do grão poderá acarretar na diminuição do valor do número de espigas das plantas. Portanto, sugere-se que o melhorista tome o cuidado de não intensificar a seleção baseada no componente peso médio do grão, ou ainda, utilize um índice de seleção que maximize o ganho nos componentes favoráveis e evite alterações nos desfavoráveis.

Outro ponto a ser lembrado é que a produção de grãos é um caráter complexo e controlado por muitos locos, sendo muito influenciado pelo ambiente, além de possuir baixa herdabilidade (Miranda Filho et al., 1972; Lima \& Paterniani, 1977; Miranda Filho et al., 1977; Ramalho, 1977; Crisóstomo, 1978; Sawazaki, 1979; Reis, 1981; Sampaio, 1986; Soares Filho, 1987; Hallauer \& Miranda Filho, 1988). Isso torna dificultoso o trabalho do melhorista em selecionar linhagens vigorosas e produtivas em programas de melhoramento que visem obtenção de linhagens para produção de hibridos. Além disso reforça a necessidade de critérios auxiliares de seleção para produção de grãos, especialmente no início desse tipo de programa de melhoramento, quando há muitas plantas a serem selecionadas. 


\subsection{Componentes da produção de grãos e sua depressão por endogamia}

Nesse ítem serão comentados e discutidos com maiores detalhes o comportamento dos componentes da produção sob o efeito da endogamia após uma geração de autofecundação artificial, e como estes afetam a redução da produção de grãos, segundo a metodologia de Grafius (1960).

As diferenças dos logaritmos dos componentes da produção de grãos foram obtidas subtraindo-se os valores dos logaritmos dos materiais não endógamos pelos endógamos, ou seja, $\log _{10}\left(S_{0}\right)-\log _{10}\left(S_{1}\right)$ (Tabela 29). A seguir essas diferenças foram transformadas em porcentagem, tomando-se o logaritmo da produção de grãos como $100 \%$ (Tabela 30 ). Uma representação gráfica das médias porcentuais de cada grupo de materiais avaliados (híbridos e variedades) pode ser observada na Figura 3. Verifica-se que as respostas à depressão por endogamia são diferentes entre os quatro componentes da produção de grãos nos grupos de materiais avaliados. No subgrupo HS observa-se que o peso médio do grão foi o componente que mais contribuiu para a diminuição da produção de grãos $(60,40 \%)$, seguido do número de espigas $(24,19 \%)$, enquanto que os componentes número de grãos por fileira $(14,34 \%)$ e o número de fileiras de grãos $(4,90 \%)$ contribuíram bem menos para a diminuição da produção. No subgrupo HT o componente número de espigas apresentou a maior contribuição para a diminuição da produção de grãos $(37,7 \%)$, seguido de perto pelo peso médio do grão $(35,0 \%)$, enquanto que os componentes número de grãos por fileira $(28,49 \%)$ e o número de fileiras de grãos $(0,43 \%)$ contribuíram bem menos para a diminuição da produção. Nesse subgrupo a contribuição do componente número de fileiras de grãos $(0,43 \%)$ foi baixa, o que pode ser explicado pelo fato desse caráter apresentar valores de $S_{1}$ próximos aos de $S_{0}$, o que resultou em diferenças logarítmicas muito pequenas. Portanto, os valores próximos de $S_{1}$ e $S_{0}$ revelam que a depressão por endogamia para o caráter número de fileiras de grãos foi muito baixa dentro do subgrupo HT. Observado os valores porcentuais dos componentes que contribuem para a redução da produção de 
grãos no subgrupo $\mathrm{HD}$, verifica-se que o número de espigas novamente participa com a maior contribuição (39,93\%), seguido desta vez pelo componente número de grãos por fileira $(30,4 \%)$, sendo que os componentes que menos contribuíram para a queda da produção de grãos foram o peso médio do grão $(27,23 \%)$ e o número de fileiras de grãos $(5,10 \%)$. No grupo das variedades o componente número de espigas apresenta uma grande contribuição para a diminuição da produção de grãos $(47,4 \%)$ em relação ao segundo maior componente, que foi o número de grãos por fileira $(28,0 \%)$, enquanto que os componentes peso médio do grão e o número de fileiras de grãos tiveram baixos valores, $20,53 \%$ e $4,08 \%$, respectivamente.

Deve-se observar que nos subgrupos $\mathrm{HT}$ e $\mathrm{HD}$ a distribuição das depressões dos componentes da produção de grãos foi menos variável que em HS e variedades, sendo que nesses dois últimos grupos de materiais houve dois componentes distintos que mais contribuíram para a diminuição da produção de grãos, a saber: o peso médio do grãos no subgrupo do HS $(60,40 \%)$ e o número de espigas no grupo das variedades $(47,38 \%)$ (Tabela 30$)$.

Não se deve esquecer de que os valores porcentuais obtidos para cada componente em cada material, foram calculados tomando-se o logaritmo da diferença entre as produções de grãos de $S_{0}$ e $S_{1}$ como valor $100,00 \%$. Como cada material apresentou depressão por endogamia diferente para a produção de grãos, deve-se tomar cuidado nas comparações entre os valores porcentuais das depressões por endogamia. Por exemplo, o valor de produção de grãos tomada como 100,00\% para o híbrido simples ZENECA 8392 corresponde a 579172 miligramas por parcela, enquanto que para o híbrido simples XL 212 foi de 1620750 (Tabela 30).

Numa análise da magnitude do valor porcentual dos componentes da produção de grãos entre os diferentes materiais genéticos avaliados, pode-se destacar que o peso médio do grão apresentou os maiores valores porcentuais para HS, seguido de HT, HD e depois variedades. Essa seqüência de decréscimo do valor desse componente pode ser explicada em razão do nivel de heterozigosidade apresentado por esses subgrupos, ou seja, do subgrupo HS para HT, e por sua vez para HD o nível de 
heterozigose diminui, atingindo os niveis mais baixos no grupo das variedades. Como a depressão por endogamia é diretamente proporcional ao nível de heterozigosidade do material para um determinado caráter (Falconer, 1989; Souza Júnior \& Fernandes, 1997), então espera-se exatamente essa seqüência de depressão citada acima para os materiais avaliados neste trabalho. Além disso, pode-se afirmar que o grupo das variedades apresentou valores baixos de depressão por endogamia para o componente peso médio do grão por, provavelmente, apresentar baixa quantidade de genes deletérios, uma vez que se tratam de variedades em sua maioria já melhoradas (Tabela 30).

Outro ponto a ser observado é que ocorreu uma compensação da participação dos componentes para a diminuição da produção de grãos, em todos os diferentes grupos genéticos. Esse efeito pode ser visivelmente observado para os componentes peso médio do grão e número de espigas. Uma depressão por endogamia alta em um desses componentes gera depressão baixa no outro, e vice-versa. Este fato está perfeitamente concordante com o observado em termos de biologia da planta, pois as plantas que produzem uma só espiga, em geral apresentam maior peso de grãos do que aquelas que são prolíficas (Tavares, 1971; Motto \& Moll, 1983) (Figura 3). Além disso, na literatura há referências de que o peso de grãos contados correlaciona-se negativa e significativamente com o número de espigas, como por exemplo, Vianna (1977), Regazzi (1978), Cruz (1983) e Mauro (1990). Vianna (1977) afirma que ao serem selecionadas plantas que produzam maior número de espigas, seleciona-se também, plantas que produzam grãos menores.

Deve ser observado que, dentre os componentes da produção de grãos, o número de espigas e o número de fileiras apresentaram valores porcentuais negativos em alguns materiais avaliados, indicando que a média de $S_{1}$ foi superior a $S_{0}$. Isso indica ausência de depressão por endogamia nesses materiais e para esses componentes. Para o componente número de espigas a variedade HS- 1 apresentou valor de $-1,52 \%$, o que está muito abaixo da variação porcentual desse componente para esse grupo, que é de $40,50 \%$ a $64,54 \%$. Em compensação a isso, a depressão por endogamia para o peso médio do grão nessa variedade foi muito alta, $42,60 \%$, e está muito acima da variação de 
depressão apresentada para o grupo das variedades para esse componente, que é de $13,09 \%$ a $28,84 \%$ (Tabela 30 ).

O componente número de grãos por fileira manteve valores porcentuais muito semelhantes entre os subgrupos $\mathrm{HT}$ e $\mathrm{HD}$, e o grupo das variedades: $28,49 \%$, $30,44 \%$ e $28,00 \%$, respectivemente. O subgrupo HS apresentou o menor valor para esse caráter $(17,34 \%)$, em virtude do baixo número de materiais estudados, que foi apenas 3 . Deve-se notar, também, que o componente número de fileiras de grãos foi o que menos contribuiu para a diminuição da produção de grãos em todos os materiais estudados. Os subgrupos $\mathrm{HS}$ e $\mathrm{HD}$, e o grupo das variedades apresentaram valores porcentuais muito semelhantes: $4,90 \%, 5,10 \%$ e $4,08 \%$, respectivamente. O subgrupo HT apresentou o menor valor para esse caráter $(0,43 \%)$, o que pode ser explicado em razão de haver baixa depressão para esses materiais híbridos avaliados nesse caráter (Tabela 30).

Na comparação dos resultados gráficos da Figura 3 com os das Figuras 1 e 2, observa-se que, de maneira geral, não há relação direta entre os componentes de maior contribuição à produção de grãos com os de maior contribuição à diminuição da produção de grãos, com exceção do componente peso médio do grão no subgrupo dos HS. Da comparação desses gráficos vê-se que apesar do componente peso médio do grão ser o principal componente responsável pelo rendimento da produção de grãos em todos os materiais genéticos avaliados (híbridos e variedades), ele apresentou alta contribuição para a depressão por endogamia da produção de grãos nesses materiais, tendo variado de $20,5 \%$ no grupo VAR a $60,4 \%$ no HS. Por outro lado, o componente número de fileiras apresentou a menor contribuição para a depressão por endogamia da produção de grãos nos grupos de materiais avaliados; entretanto, sua contribuição para a produção de grãos não foi expressiva. Os demais componentes da produção, número de grãos por fileira e número de espigas, além de apresentarem alta contribuição para a depressão por endogamia da produção de grãos, não tiveram expressiva contribuição para a produção de grãos. Assim sendo, não foi possivel discriminar nenhum componente da produção que se destacasse dos demais para serem utilizados como critério auxiliar na seleção de linhagens mais produtivas utilizando a metodologia de Grafius (1960). 
No ítem em que se discutiu a depressão por endogamia de vários caracteres avaliados nesse trabalho (item 4.2), verificou-se que, enquanto a produção de grãos apresenta alta depressão por endogamia média entre grupos de materiais $(32,42 \%$ a $41,17 \%$ ), todos os quatro componentes da produção de grãos considerados por Grafius (1960) apresentam baixa depressão por endogamia em comparação com a da produção de grãos, a saber: número de espigas (8,50\% a 19,79\%), número de grãos por fileira (7,43\% a 15,51\%), número de fileiras de grãos $(0,56 \%$ a 2,80\%) e peso de 500 grãos $(8,04 \%$ a $23,58 \%)$ (Tabelas $11,12,17,22$ e 23$)$. Verifica-se, portanto, que a depressão por endogamia calculada individualmente para cada componente, não reflete a contribuição real desses componentes para a depressão por endogamia da produção de grãos. Esse fato é explicado em razão da produção de grãos ser o produto da multiplicação de tais componentes, e assim sendo, os baixos valores de depressão por endogamia apresentados pelos componentes se multiplicam, gerando uma elevada depressão por endogamia para a produção de grãos. Além disso, verifica-se que a produção de grãos apresenta uma estimativa do componente (d), muito superior ao de $(\mu+a)$, enquanto que para os seus componentes ocorre o contrário. Isso demonstra que os componentes da produção têm caráter aditivo, enquanto a produção de grãos têm caráter não aditivo. Em vista disso, pode-se afirmar que a seleção de linhagens baseada nos componentes da produção será mais eficaz que aquela baseada na produção, pois as estimativas do componente $(\mu+a)$ dos componentes são parâmetros oferecem grande robustez e confiança. Essas informações são muito importantes pois reforçam ainda mais a idéia de se tomar como critério auxiliar de seleção para a produção de grãos um de seus componentes (Teixeira, 1978 ).

Outro ponto a ser observado é a facilidade de mensuração dos componentes da produção. Os componentes número de fileiras de grãos, número de grãos por fileira e peso médio do grão (ou peso de grãos contados) são tão dificeis de serem mensurados quanto a produção de grãos. Assim sendo, pode-se afirmar que é preciso escolher como caráter auxiliar para seleção aquele componente que apresente ao mesmo tempo, grande contribuição para a produção, baixa depressão por endogamia e, 
facilidade de mensuração. $\mathrm{O}$ componente número de espigas da parcela é mais fácil de ser avaliado do que os outros componentes, sendo que essa avaliação pode ser feita no campo, antes do florescimento das plantas (Motto \& Moll, 1983; Souza Júnior et al., 1985). Visto que, o número de espigas é um componente que contribui significativamente para a produção de grãos, $16,94 \%$ a $20,55 \%$ (Tabela 28 ), apresenta depressão por endogamia relativamente baixa em comparação com a da produção de grãos, $8,50 \%$ a 19,79\% (Tabela 17), e sendo de fácil mensuração, poderia ser recomendado como critério auxiliar na seleção de linhagens produtivas.

De modo geral, as evidências apontam para apenas um componente da produção que poderia ser tomado como critério auxiliar na seleção para a produção de grãos: o número de espigas da parcela.

\subsection{Considerações gerais}

De modo geral, verificou-se que o grupo dos híbridos sofreram maior depressão por endogamia que o grupo das variedades para todos os caracteres avaliados. Isso pode ser explicado pelo fato dos materiais hibridos, apresentando alto nível de heterozigose para a maioria dos caracteres avaliados, quando submetidos a autofecundação artificial, permitiram que as combinações de genes ideais para a expressão otimizada da característica sejam desfeitas. Por outro lado, espera-se que as variedades apresentem níveis mais baixos de heterozigose que os híbridos, o que pode ter conferido uma depressão por endogamia não tão acentuada quanto nos híbridos para a maioria dos caracteres avaliados. Além disso, acredita-se que as variedades avaliadas demonstraram ter baixa quantidade de genes desfavoráveis (deletérios).

Deve ser ressaltado que as diferenças observadas nos valores porcentuais de depressão por endogamia para cada caráter é decorrente da natureza genética exibida. Hallauer \& Miranda Filho (1988) relataram que os elevados valores 
observados para peso de grãos e de espigas estão relacionados com o elevado grau de dominância, quando comparados à caracteres com alta herdabilidade. Falconer (1989) enfatizou que as maiores depressões por endogamia devem ser encontradas em caracteres controlados por maior número de genes dominantes, em populações com elevada frequeência de heterozigotos em locos com dominância, e em populações com alta carga genética. Tais afirmações confirmam os resultados obtidos no presente trabalho para os diversos caracteres avaliados nos diferentes materiais estudados.

A depressão média por endogamia variou em função do material genético (tipo de hibrido e tipo de variedade) e também da natureza do caráter em estudo. Os caracteres com maior depressão por endogamia foram o peso de espigas despalhadas $(\mathrm{Kg} / \mathrm{ha})$ com valor médio em torno de $41 \%$, e a produção de grãos $(\mathrm{Kg} / \mathrm{ha})$ com valor médio em torno de $36 \%$. Os caracteres DE, DS, NF, CE, AE e ES tiveram depressão por endogamia média dos grupos variando entre $0,0 \%$ a $10,0 \%$, enquanto que $\mathrm{PG}_{500}$, AP, NE, PROL, NGF e PROF tiveram variação de $10,0 \%$ a $20,0 \%$. O caráter PRE não apresentou depressão por endogamia em nenhum material.

Em programas de obtenção de linhagens, durante o processo de autofecundação, a grande quantidade de linhagens obtidas leva o melhorista a tomar o critério de selecionar as que forem mais produtivas e descartar as menos produtivas. Como durante o processo de autofecundação ocorre drástica diminuição da produção, em razão do efeito da endogamia, pode-se tomar como critério auxiliar para seleção de linhagens produtivas alguns dos componentes que fazem parte da produção e que apresentem menor depressão por endogamia que a produção de grãos. Além disso, a alta herdabilidade de alguns componentes, sua positiva e significativa correlação com a produção de grãos e alto componente aditivo $(\mu+a)$ consolidam ainda mais a possibilidade de serem tomados como critério auxiliar na seleção das melhores linhagens para as seguintes autofecundações durante o processo de obtenção de linhagens. Portanto, o conhecimento do comportamento da produção através de seus componentes permite realizar uma seleção de maneira mais adequada, com o objetivo de se obterem plantas mais eficientes quanto à produção de grãos. Falconer (1989) relata que o 
melhoramento da produção de grãos pela seleção de seus componentes seria superior à seleção para produção, "per se", quando o componente desta tivesse uma herdabilidade maior que a produção e quando a correlação genética entre o componente e a produção fosse alto. Entretanto, não se deve esquecer de que a medição desses componentes não é tão fácil e prática, o que dificulta sua utilização. Além disso, deve-se lembrar do efeito de compensação entre os componentes da produção, como por exemplo, o número de espigas e o peso de grãos contados. Seleções muito intensas para um destes componentes levará a diminuições do outro.

Com uma herdabilidade comprovadamente baixa a produção de grãos, embora seja objetivo maior do melhoramento, não pode ser tomada como único critério de seleção, especialmente nas gerações iniciais do processo de melhoramento, quando a seleção é feita para grande quantidade de plantas. Desse modo, o estudo das relações entre caracteres, em especial dos componentes da produção, e a produção de grãos tem contribuído de maneira a tornar o processo mais eficiente. Dentro desse contexto pode-se destacar a utilização da metodologia de Grafius (1960), que permite acompanhar a relação entre a produção de grãos e seus componentes.

O estudo dos componentes da produção não só pode auxiliar a seleção de linhagens em programas de obtenção de linhagens, mas também para outros propósitos, como por exemplo, na escolha do método a ser empregado no melhoramento genético de plantas. Para esses estudos é de grande interesse a utilização de informações mais precisas, de modo a permitir ao melhorista, saber o que está ocorrendo no processo de melhoramento. A seleção para aumento da produção de grãos auxiliada por um de seus componentes é um dos pontos importantes a ser considerado nos programas de melhoramento que visem produção de linhagens. Considerações de natureza teórica (Grafius, 1960; Falconer, 1989) e prática (Tavares, 1971) têm revelado que a seleção para produção de grãos auxiliada por um ou mais de seus componentes apresenta-se como eficiente ferramenta promotora de ganhos genéticos nas linhagens, reduzindo a sua depressão por endogamia. 
A produção de grãos representa o último produto da interação de numerosas variáveis, cujos efeitos individuais não podem ser prontamente identificados. Por esta razão considera-se que a avaliação da produção continuará como comumente é feita, apesar dos esforços para decompor a produção em componentes. Moll et al.(1962) reconhecem que os componentes da produção podem ser medidos com muito menor erro do que a produção "per se", e em virtude de serem caracteres altamente correlacionados com a produção, obviamente são muito úteis como ajuda ao melhoramento da produção. Deve-se considerar também que, além do aspecto prático, é amplamente reconhecida a conveniência de identificar os fatores e interações implícitos na expressão da produção, para que se possa caracterizar mais precisamente as condições ótimas de sua avaliação. Como pôde ser observado, os resultados apresentados neste trabalho permitiram que seja feita mais uma apreciação relativa a estes aspectos.

A metodologia de Grafius (1960) mostrou-se eficaz no presente trabalho, pois os componentes da produção de grãos foram melhor avaliados quanto a relação que apresentam com a produção de grãos. Verificou-se que para todos os materiais genéticos avaliados (híbridos e variedades), tanto em $S_{o}$ quanto $S_{1}$, o peso médio do grão é o principal componente da produção de grãos, sendo responsável por cerca de 38,0\% desta, enquanto que os demais componentes, apresentam uma contribuição individual semelhante para a produção de grãos $(\cong 20,0 \%$ ) (Tabela 28 e Figuras 1 e 2). Além disso, a avaliação da depressão por endogamia dos componentes da produção através de Grafius (1960) mostrou que todos os componentes contribuem muito para a depressão por endogamia da produção de grãos. Entretanto, constatou-se que essa metodologia apresenta a desvantagem de ser dependente da unidade de medida dos componentes da produção de grãos, o que dificulta a sua utilização prática.

Levando em consideração os resultados deste trabalho, pode-se inferir que o número de espigas por parcela é o caráter com maior potencial a ser utilizado no processo seletivo de linhagens, quando o objetivo é o incremento na produção de grãos, especialmente nas gerações iniciais. Entretanto, apresenta alta contribuição para a depressão por endogamia da produção de grãos no grupo das variedades em comparação 
com os demais componentes. Apesar de não ser o componente que mais contribui para a produção de grãos, ele tem participação significativa em torno de $\cong 20 \%$. Além disso, esse componente apresenta alta herdabilidade em comparação com a produção de grãos, apresenta correlação positiva e significativa com a produção de grãos, sendo também um caráter de fácil mensuração. Deve-se ressaltar que as estimativas do componente $(\mu+a)$ para esse componente são altas em relação a produção de grãos, o que permite robustez e confiança na seleção de linhagens mais produtivas. Entretanto, deve ser lembrado que há competição entre os componentes da produção, em especial entre o número de espigas e o peso de grãos contados, que pode limitar o progresso na seleção se esta for direcionada para apenas um destes.

Apesar da redução na produção de grãos por ocasião da autofecundação ser muito abordada na literatura, estudos mais detalhados envolvendo os seus componentes ainda são muito escassos, por isso merecem mais atenção. Esses estudos poderiam proporcionar maior aplicabilidade para a fórmula de Grafius (1960), especialmente quanto a unidade dos dados a ser empregada.

Embora trabalhos da literatura mostrem que o estudo dos componentes da produção de grãos poderia auxiliar na escolha de materiais para programas de seleção com base na produção, como verificado por McMullan et al. (1988), Payne et al. (1986) e Teixeira (1978), este tipo de estudo é pouco realizado em razão da grande dificuldade prática para mensuração dos caracteres neles envolvidos. Portanto, esse estudo, de grande relevância para programas de melhoramento de milho, mereceria mais atenção por parte dos pesquisadores, não só de milho, mas também de outras culturas em que possa ser empregado. 


\section{CONCLUSÕES}

Nas condições do presente trabalho, as interpretações dos resultados obtidos permitiram apontar as seguintes conclusões:

a) A depressão por endogamia, na maioria dos caracteres avaliados, foi sempre maior no grupo dos hibridos que das variedades;

b) O componente peso médio do grão foi o principal responsável pela maior parte do valor médio da produção de grãos tanto em $S_{0}$ como em $S_{1}$, contribuindo com cerca de $38,0 \%$, enquanto que os componentes número de espigas por parcela, número de grãos por fileira e número de fileiras de grãos contribuiram com cerca de $20,0 \%$ cada um;

c) A contribuição dos componentes da produção de grãos para a depressão por endogamia da produção foram variáveis dentro de cada grupo de materiais avaliados, sendo que o peso médio do grão foi o maior responsável pela queda da produção de grãos no grupo dos hibridos simples $(60,40 \%)$, enquanto que o número de espigas por parcela foi o grande responsável nas variedades $(47,38 \%)$;

d) O número de espigas por parcela é o único componente da produção de grãos com maior potencial para ser utilizado como critério auxiliar na seleção de linhagens mais produtivas. 


\section{REFERÊNCIAS BIBLIOGRÁFICAS}

ALEXANDER, W.L.; SMITH, E.L.; DHANASOBHAN, C. A comparison of yield component selection in winter wheat. Euphytica, v.33, p.953-961, 1984.

ALLARD, R.W. Principles of plant breeding. New York: John Willey and Sons, 1960. $485 p$.

AUSTIN, D.F.; LEE, M. Detection of quantitative trait loci for grain yield and yield components in maize across generations in stress and nonstress environments. Crop Science, v.38, n.5, p.1296-1308. 1998.

BENSON, D.L.; HALLAUER, A.R. Inbreeding depression rates in maize populations before and after recurrent selection. Journal of Heredity, v.85, p.122-128, 1994.

BLANDÓN, S. C. Efeito da deriva genética sobre caracteres quantitativos em uma população de milho (Zea mays L.). Piracicaba, 1996. 90p. Tese (Doutorado) Escola Superior de Agricultura 'Luiz de Queiroz", Universidade de São Paulo.

BURTON, J.W.L.; PENNY, L.H.; HALLAUER, L.H.; EBERHART, S. Evaluation of synthetic populations developed from maize variety (BSK) by two methods of recurrent selection. Crop Science, v.11, p.361-365, 1971. 
CASTRO, G.M.; GARDNER, C.O.; LONNQUIST, J.H. Cumulative gene effects and the nature of heterosis in maize crosses involving genetically diverse races. Crop Science, v.8, p. 97-101, 1968.

CHARLESWORTH, D.; CHARLESWORTH, B. Inbreeding depression and its evolutionary consequences. Ann. Rev. Ecol. Syst., v.18 , p.237-268. 1987.

COCKERHAN, C. C. Covariances of relatives from self-fertilization. Crop Science, v.23, p.1177-1180, 1983.

CORNELIUS, P.L.; DUDLEY, J.W. Effects of inbreeding by selfing and full-sib mating in a maize population. Crop Science. v.14, p.815-819, 1974.

CRISÓSTOMO, J.R. Estimação de parâmetros genéticos visando seleção em dois compostos de milho (Zea mays L.). Piracicaba, 1978. 71p. Dissertação (Mestrado) Escola Superior de Agricultura 'Luiz de Queiroz", Universidade de São Paulo.

CROW, J.F. Alternative hypotheses of hybrid vigor. Genetics, v.33, p.477-487. 1948

CROW, J.F. Breeding structures of populations. II. Effective population number. In: KEMPTHORNE, O.; BANCROFT, T.A.; GOWEN, J.W.; LUSH, J.L. Statistics and mathematics in Biology. Ames, Iowa State College Press, 1954. P. 543-456.

CRUZ, C.D. Análise dialélica e correlações entre caracteres em combinações híbridas de linhagens endogâmicas de milho (Zea mays L.). Viçosa, 1983. 54p. Dissertação (M.S.) - Universidade Federal de Viçosa.

DARWIN, C. Des effects de la fécondation croisé et de la fécondation direte la fégne végétal. Paris: C. Reinwald, 1877. 496p. 
DRISCOLL, M.F.; ABEL, G.H. A correct logarithmic transformation for standardizing multiplicative trait variables. Crop Science, v.16, p.301-303, 1976.

DUDLEY, J.W.; MOLL, R.H. Interpretation and use of estimates of heritability and genetic variances in plant breeding. Crop Science, v.9, p.257-262, 1969.

DUNCAN; W.G.; McClOUD, D.E.; McGRAW, R.L.; BOOTE, K.J. Physiological aspects of peanut yield improvement. Crop Science, v.18, p.1015-1020, 1978.

EAGLES, H.A.; HARDACRE, A.K. Inbreeding depression and other genetic effects in populations of maize containing highland tropical germplasm. Plant Breeding, v.110, p.229-236. 1993.

EAST, E.M.; JONES, D.F. Inbreeding and outbreeding. Lippincott, 1918.

FALCONER, D.S. Introduction to quantitative genetics. New York: Roland Press, 1989. $438 p$.

FERNANDES, J.S.C. Progressos esperados em linhagens de milho via seleção recorrente intra e interpopulacional. Piracicaba, 1990. 235p. Tese (Doutorado) Escola Superior de Agricultura "Luiz de Queiroz”, Universidade de São Paulo.

FREY, K.J. Increasing grain yield of oats. Plant Physiology and Biochemistry, v.26, p.539-542, 1988.

GAMA, E.E.G.; HALLAUER, A.R. Relation between inbred and hybrid traits in maize. Crop Science, v. 17, p.703-706, 1977. 
GAMA, E.E.G.; VIANNA, R.T.; NASPOLINI FILHO, V.; MAGNAVACA, R. Efeito depressivo da endogamia em gerações avançadas de quatro tipos genéticos de hibridos de milho. Pesquisa Agropecuária Brasileira, v.20, n.11, p.1293-1300. 1985.

GARDNER, C.O. Teoria de genética estatística aplicable a las medias de variedades, sus cruces y poblaciones afines. Fitotecnia Latinoamericana, v.2, p.11-22, 1965.

GARDNER, C.O.; EBERHART, S.A. Analysis and interpretation of the variety cross diallel and related populations. Biometrics, v.22, p.439-453, 1966.

GENTER, C.F. Yields of $S_{1}$ lines from original and advanced synthetic varieties of maize. Crop Science, v.11, p.821-824, 1971.

GERALDI, I.O.; VENCOVSKY, R. Depressão por endogamia em populações de milho. In: REUNIÃO BRASLEIRA DE MILHO E SORGO, 13., Londrina, 1980. Resumos. Londrina: IAPAR, 1980. p.45.

GOMIDE, F.B. Cruzamentos dialélicos entre variedades de milho (Zea mays L.). Viçosa, 1980. 71p. Dissertação (M.S.) - Universidade Federal de Viçosa.

GOOD, R.L.; HALLAUER, A.R. Inbreeding depression in maize by selfing and fullsibbing. Crop Science, v.17, p.935-940, 1977.

GOULAS, K.C.; LONQUIST, J.K. Combined half-sib ans $\mathrm{S}_{1}$ family selection in a maize composite population. Crop Science, v.16, p.461-464, 1976. 
GRACEN, V.E. Source of temperate maize germplasm and potential usefullness in tropical and subtropical environments. Advances in Agronomy, v.39, p.127-173, 1986.

GRAFIUS, J. E. Heterosis in barley. Agronomy Journal, v.51, p.551-554, 1959.

GRAFIUS, J. E. Does overdominance exist for yield in corn? Agronomy Journal, v.52, p.361, 1960.

GROMBACHER, A.W.; RUSSEL, W.A.; GUTHRIE, W.D. Effects of reccurrent selection in two maize synthetics on agronomic traits of $S_{1}$ lines. Maydica, v.34, n.4, p.343-352. 1989.

HALlAUER, A.R.; MIRANDA FILHO, J.B. Quantitative genetics in maize breeding. Ames: Iowa State University Press, 1988. 468p.

HALLAUER, A.R.; RUSSELL, W.A.; LAMKEY, K.R. Corn breeding. In: SPRAGUE, G.F. \& DUDLEY, J.W. Corn and corn improvement. 3rd ed. Madison, Am. Soc. of Agron., 1988. P.463-564.

HALLAUER, A.R.; SEARS, J.H. Changes in quantitative traits associated with inbreeding in a synthetic variety of maize. Crop Science, v.13, p.327-330, 1973.

HARDWICK, R.C.; ANDREWS, D.J. Genotypic and environmental variation in crop yield. A method of estimating the interdependence of the components of yield. Euphytica, v.29, p.177-188, 1980. 
HARRIS, R.E.; GARDNER, C.O.; COMPTON, W.A. Effects of mean selection and irradiation in corn measured by random $S_{1}$ lines and their crosses. Crop Science, v.12, p.594-598, 1972.

HOLTHAUS, J.F.; LAMKEY, K.R. Response to selection and changes in genetic parameters for 13 plant and ear trais in two maize recurrent selection programs. Maydica, v.40, n.4, p.357-370, 1995.

JONES, D.F. The effects of inbreeding and crossbreeding upon development. Bulletin of the Connecticut Agricultural Experiment Station, v.207, p.5-100, 1918.

JONES, D.F. Continued inbreeding in maize. Genetics, v.24, p. 462-473, 1939.

KEMPTHORNE, $\mathrm{O}$. The desing and analysis of experiments. New York: John Wiley \& Sons, 1952. 631p.

LAMKEY, K.R.; SMITH, O.S. Performance and inbreeding depression of populations representing seven eras of maize breeding. Crop Science, v.27, p. 695-659, 1987.

LANDE, R.; SCHEMESKE, D.W. The evolution of self-fertilization and inbreeding depression in plants I. Genetic models. Evolution, v.39, p.24-40. 1985.

LENG, E.R. Expression of heterosis and apparent degree of dominance in the major componentes of grain yield in maize. Genetics, v.38, p. 674-675, 1953.

LENG, E.R. Effects of heterosis on the major componentes of grain yield in corn. Agronomy Journal, v.46, p. 502-506, 1954. 
LIMA, M. Seleção entre e dentro de famílias de meios irmãos na população de milho (Zea mays L.) ESALQ VD-2. Piracicaba, 1977. 71p. Dissertação (Mestrado) Escola Superior de Agricultura "Luiz de Queiroz", Universidade de São Paulo.

LIMA, M.; GIMENES FERNANDES, N.; MIRANDA FILHO, J.B.; PEREIRA, J.C.V.A Introduction of maize (Zea mays L.) germplasms as sources for downy mildew (Peronosclerospora sorghi) resistence. Maydica, v.27, p.159-168, 1982.

LIMA, M.; MIRANDA FILHO, J.B.; GALLO, P.B. Inbreeding depression in Brasilian populations of maize (Zea mays L.). Maydica, v.29, p.203-215, 1984.

LIMA, M.; PATERNIANI, E. Estimativas de parâmetros genéticos e fenotípicos em progênies de meios-irmãos de milho (Zea mays L.) ESALQ-VD-2 MI - HSII e suas implicações no melhoramento. Relatório Científico do Departamento de Genética da ESALQ. Piracicaba, v.11, p. 84-89, 1977.

LINDSTRON, E.W. Analysis of modern maize breeding principles and methods. Proc. $7^{\text {th }}$ International Genetic Congress, v.7, p. 191-196. 1939.

LYNCH, M. Design and analysis of experiments on random drift and inbreeding depression. Genetics, v.120, p.791-807, 1989.

MALECOT, G. Les mathematiques de L'Hérédité. Paris, Masson et Cie., 1948. 63p.

MALVAR, R.A.; ORDÁS, A.; REVILLA, P.; CARTEA, M.E. Estimates of genetic variances in two spanish populations of maize. Crop Science, v.36, n.2, p. 291-295. 1996. 
MARIOTE, D. Avaliação do potencial genético de duas populações de milho (Zea mays L.) e suas implicações no melhoramento do teor de óleo. Piracicaba, 1993. 101p. Dissertação (Mestrado) - Escola Superior de Agricultura "Luiz de Queiroz", Universidade de São Paulo.

MARQUES, J.R.B. Seleção recorrente com endogamia em duas populações de milho (Zea mays L.). Piracicaba, 1988. 145p. Dissertação (Mestrado) - Escola Superior de Agricultura "Luiz de Queiroz", Universidade de São Paulo.

MAURO, S. M. Z. Avaliação da variabilidade genética e do potencial do composto dentado para seleção recorrente recíproca em milho (Zea mays L.) Viçosa, 1990. 95p. Dissertação (M.S.) - Universidade Federal de Viçosa.

McMULLAN, P.M.; McVETTY, P.B.E.; URQUHART, A.A. Dry matter and nitrogen accumulation and redistribuition and their relationship to grain yield and grain protein in oats. Canadian Journal of Plant Science, v.68, p.983-993, 1988.

MEGHJI, M.R.; DUDLEY, J.W.; LAMBERT, R.J.; SPRAGUE, G.F. Inbreeding depression, inbred and hybrid grain yields, and other traits of maize genotypes representing three eras. Crop Science. v.24, p.545-549, 1984.

MEHTA, H.; SARKAR, K.R. Heterosis for leaf photosyntesis, grain yield and yield components in maize. Euphytica, v.61, p.161-168, 1992.

MIRANDA FILHO, J.B.; VENCOVSKY, R.; PATERNIANI, E. Variância genética aditiva da produção de grãos em dois compostos de milho e sua implicação no melhoramento. Relatório Científico do Departamento de Genética da ESALQ. Piracicaba, v.6, p. 67-73, 1972. 
MIRANDA FILHO, J.B.; VIEGAS, G.P. Milho híbrido. In: PATERNIANI, E.; VIEGAS, G.P. (Ed.) Melhoramento e produção do milho. 2.ed., Campinas: Fundação Cargill, 1987. v. 1, p. 277-340.

MIRANDA, L.T.; MIRANDA, L.C.E.; POMMER, C.V.; SAWAZAKY, E. Estimativas de parâmetros genéticos na população de milho IAC-1 Opaco-2. Bragantia, v.36, p. 197-205, 1977.

MOLL, M.R.: KOJIMA, K.; ROBINSON, H.F. Components of yield and overdominance in corn. Crop Science, v.2, p. 78-79, 1962.

MORERA, J.A. Comparison of two breeding methods in com II. Determination of inbreeding depression. Turrialba, v.39, n.1, p.68-71. 1989.

MÔRO, J.R. Efeito da alta intensidade de seleção no melhoramento de milho (Zea mays L.) Piracicaba, 1982. 52p. Dissertação (Mestrado) - Escola Superior de Agricultura "Luiz de Queiroz", Universidade de São Paulo.

MOSER, H.S.; FREY, K.J. Yield component responses associated with increased yield after recurrent selection in oat. Crop Science, v.34, p.915-922, 1994.

MOTA, M.G. da C. Comportamento de progênies de meios irmãos e $S_{1}$ na variedade de milho (Zea mays L.) Centralmex. Piracicaba, 1974. 73p. Dissertação (Mestrado) Escola Superior de Agricultura "Luiz de Queiroz", Universidade de São Paulo.

MOTTO, M.; MOLL, R.H. Prolificacy in maize: a review. Maydica, v.28, p.53-76, 1983. 
NASPOLINI FILHO, V. Variabilidade fenotípica e estabilidade em híbridos simples, híbridos duplos, variedades e compostos de milho (Zea mays L.). Piracicaba, 1975. 68p. Dissertação (Mestrado) - Escola Superior de Agricultura "Luiz de Queiroz", Universidade de São Paulo.

NASS, L.L. Variabilidade genética de populações semi-exóticas de milho. Piracicaba, 1992. 136p. Tese (Doutorado) - Escola Superior de Agricultura "Luiz de Queiroz", Universidade de São Paulo.

NASS, L.L.; MIRANDA FILHO, J.B. Inbreeding depression rates of semi-exotic maize (Zea mays L.) populations. Brazilian Journal of Genetics, Ribeirão Preto, v.18, n. 4, p.585-592, 1995.

ODHIAMBO, M.O.; COMPTON, W.A. Five cycles of reciprocal $S_{1}$ vs reciprocal fullsib index selection in maize. Crop Science, v.29, p.314-319, 1989.

OYERVIDES-GARCIA, M.; HALLAUER, AR. Selection induced differences among strains of Iowa Stiff Stalk Synthetic maize. Crop Science, v.26, p.506-511, 1986.

PATERNIANI, E. Heterosis in intervarietal crosses of maize (Zea mays L.) and their advanced generations. Revista Brasileira de Genética, v.3, p. 235-249, 1990.

PATERNIANI, M.E.A.G.Z. Efeitos da redução do tamanho de populações de milho (Zea mays L.). Piracicaba, 1995. 117p. Tese (Doutorado) - Escola Superior de Agricultura "Luiz de Queiroz", Universidade de São Paulo.

PAYNE, T.S.; STUTHMAN, D.D.; McGRAW, R.L.; BREGITZER, P.P. Physiological changes associated with three cycles of recurrent selection for grain yield improvement in oats. Crop Science, v.26, p.734-736, 1986. 
PEREIRA, R.S.B. Caracteres correlacionados com a produção e suas alterações no melhoramento genético do milho (Zea mays L.). Piracicaba, 1990 99p. Dissertação (Mestrado) - Escola Superior de Agricultura "Luiz de Queiroz", Universidade de São Paulo.

PEREIRA, M.B.; VENCOVSKY, R. Limites de seleção recorrente. I. Fatores que afetam o acréscimo das frequêencias alélicas. Pesquisa Agropecuária Brasileira, v.23, f.7, p.769-780, 1988.

PIEPHO, H.P. A simple procedure for yield component analysis. Euphytica, v.84, p. $43-48,1995$.

PINHO, E.U.R.V. Conseqüência da autofecundação indesejável na produção de sementes híbridas de milho. Piracicaba, 1995 130p. Tese (Doutorado) - Escola Superior de Agricultura 'Luiz de Queiroz", Universidade de São Paulo.

PINTO, L.R.M.; SILVA, J.C.; SILVA, M.A.; SEDIYAMA, C.S. Estimativas de constantes genéticas para produção de grãos pela análise das médias em um cruzamento dialélico entre oito variedades de milho (Zea mays L.). Revista Ceres, v.32, p.132-148, 1985.

PINTO, L.R.M.; SILVA, J.C.; SILVA, M.A.; SEDIYAMA, C.S. Estimação da depressão causada pela endogamia e do rendimento de linhagens pela análise das médias de um dialelo entre oito variedades de milho (Zea mays L.). Revista Ceres, v. 12, p.67-80, 1989.

PURI, Y.P.; QUALSET, C.D.; WILLIAMS, W.A. Evaluation of yiled components as selection criteria in barley breeding. p. 90-96, Proc. $4^{\text {th }}$ International Barley Genetic Symposium, July. Edinburgh University Press, 1981. 
RALLS, K.; BALLOU, J.D.; TEMPLETON, A. Estimates of lethal equivalents and cost of inbreeding in mammals. Conserv. Biology, v.2, p.185-193. 1988.

RAMALHO, M.A.P. Eficiência relativa de alguns processos de seleção intrapopulacional no milho (Zea mays L.) baseados em famílias não endógamas. Piracicaba, 1977. 122p. Tese (Doutorado) - Escola Superior de Agricultura "Luiz de Queiroz", Universidade de São Paulo.

RAMALHO, M.A.P.; SANTOS, J.B.; ZIMMERMANN, M.J.O. Genética quantitativa em plantas autógamas. Editora UFG, 1993. 271p.

RASMUSSON, D.C. An evaluation of ideotype breeding. Crop Science, v.27, p. 11401146, 1987.

REGAZZI, A.J. Variâncias, covariâncias genéticas e índices de seleção num composto de milho (Zea mays L.). Viçosa, 1978. 57p. Dissertação (M.S.) - Universidade Federal de Viçosa.

REIS, F.P. Herdabilidades, correlações e indices de seleção em milho (Zea mays L.). Viçosa, 1981. 65p. Dissertação (M.S.) - Universidade Federal de Viçosa.

REZENDE, G. D. S. P. Heterose, depressão por endogamia e variabilidade genética associada à seleção e oscilação genética nas populações de milho BR-105 e BR-106. Piracicaba, 1997. 111p. Tese (Doutorado) - Escola Superior de Agricultura "Luiz de Queiroz", Universidade de São Paulo.

RIBEIRO, P.H.E. Avaliação de progênies $S_{1}$ e $S_{2}$ do composto duro de milho (Zea mays L.) e estimação de variabilidade genética. Viçosa, 1990. 72p. Dissertação (M.S.) Universidade Federal de Viçosa. 
ROBINSON, H.F.; COCKERHAM, C.C. Heterosis and inbreeding depression in populations involving two open-pollinated varieties of maize. Crop Science, v.1, p. 68-71, 1961.

ROBINSON, H.F.; COMSTOCK, R.E.; HARVEY, P.H. Genotypic and phenotypic correlations in corn and their implications in selection. Agronomy Journal, v.43, p.282-287, 1951.

RODRIGUEZ, O.A.; HALLAUER, A.R. Effects of recurrent selection in corn populations. Crop Science, v.28, p. 796-800, 1988.

SAMPAIO, N.F. Propriedades genéticas e potencial para o melhoramento dos compostos de milho (Zea mays L.) ESALQ PB-4 e ESALQ PB-5. Piracicaba, 1986. 105p. Dissertação (Mestrado) - Escola Superior de Agricultura "Luiz de Queiroz", Universidade de São Paulo.

SAS INSTITUTE INC. Statistical Analysis System. Release 6.08, (software). Cary, 1992.

SAWAZAKI, E. Treze ciclos de seleção entre e dentro de familias de meios irmãos para produção de grãos em milho IAC MAYA. Piracicaba, 1979. 100p. Dissertação (Mestrado) - Escola Superior de Agricultura "Luiz de Queiroz", Universidade de São Paulo.

SAWAZAKI, E. Parâmetros genéticos em milho (Zea mays L.) pipoca. Piracicaba, 1996. 157p. Tese (Doutorado) - Escola Superior de Agricultura "Luiz de Queiroz", Universidade de São Paulo. 
SHULL, G.H. A pure-line method in corn breeding. American Breeders Association Report, v.5, p.51-59, 1909.

SHULL, G.H. The composition of a field of maize. American Breeders Association Report, v.4, p. 296-301, 1908.

SILVA, C.H.O. Seleção recorrente recíproca em milho (Zea mays L.) usando familias de irmãos germanos, realizada em cruzamentos entre o 'Sintético Duro UFV' e o 'Sintético Dentado UFV'. Viçosa, 1991. 84p. Dissertação (M.S.) - Universidade Federal de Viçosa.

SILVA, J.C.; PINTO, L.R.M. Depressão por endogamia em seis variedades de milho opaco-2. Revista Ceres, v.29, n.162, p.164-175, 1982.

SILVEIRA, M.G. Avaliação da variabilidade genética de híbridos crípticos interpopulacionais de milho (Zea mays L.) em dois ciclos de seleção recorrente recíproca. Viçosa, 1990. 60p. Dissertação (M.S.) - Universidade Federal de Viçosa.

SING, C.F.; MOLL, R.H.; HANSON, W.D. Inbreeding in two populations of Zea mays L. Crop Science, v.7, p.631-636, 1967.

SMAIL, V.W.; ESLICK, R.F.; HOCKETT, E.A. Isogenic heading date effects on yield component development in 'Titan' Barley. Crop Science, v.26, p. 1023-1028, 1986.

SOARES FILHO, W.S. Características fenotípicas e genotípicas das populações de milho (Zea mays L.) Braquítico Piranão - VD2B e Piranão - VF1B. Piracicaba, 1987. 185p. Tese (Doutorado) - Escola Superior de Agricultura "Luiz de Queiroz", Universidade de São Paulo. 
SOUZA JÚNIOR, C.L. Procedures for estimating expected genetic progress inbred lines via recurrent intrapopulation selection. Revista Brasileira de Genética, v.8, n.2, p.329-342, 1985.

SOUZA JÚNIOR, C.L.; FERNANDES, J.S.C. Predicting the range of inbreeding depression of inbred lines in cross-pollinated populations. Brazilian Journal of Genetics, Ribeirão Preto, v.20, n.1, p.35-39, 1997.

SOUZA JÚNIOR, C.L.; GERALDI, I.O.; ZINSLY, J.R. Influence of tassel size on the expression of prolificacy in maize (Zea mays L.). Maydica, v.30, n.1, p.321-328, 1985.

SOUZA JÚNIOR, C.L.; SANTOS, M.X.; MAGNAVACA, R.; GAMA, E.E.G. Estimativas de parâmetros genéticos na interpopulação de milho BR-105 x BR-106 e suas implicações no melhoramento. Pesquisa Agropecuária Brasileira, v.28, p. 473-479, 1993.

STEBBINS, G.L. Self-fertilization and population variability in the higher plants. American Nature, v. 91, p. 337-354, 1957.

STEEL, R.G.D.; TORRIE, J.H. Principles and procedures of statistics. New York: Mc Graw-Hill, 1960. 481p.

STOSKOPF, N.C.; REINBERGS, E. Breeding for yield in spring cereals. Canadian Journal of Plant Science, v.46, p.513-519, 1966.

TATIS, H.A. Seleção para alto teor de óleo na semente de milho e seus efeitos sobre caracteres agronômicos. Piracicaba, 1990. 126p. Tese (Doutorado) - Escola Superior de Agricultura "Luiz de Queiroz", Universidade de São Paulo. 
TAVARES, F.C.A Componentes da produção relacionados a heterose em hibridos intervarietais de milho (Zea mays L.). Piracicaba, 1972. 106p. Dissertação (Mestrado) - Escola Superior de Agricultura "Luiz de Queiroz", Universidade de São Paulo.

TEIXEIRA, J.R.J. Efeitos da densidade de semeadura sobre os componentes do rendimento de três cultivares de trigo. Piracicaba, 1978. 133p. Dissertação (Mestrado) - Escola Superior de Agricultura "Luiz de Queiroz", Universidade de São Paulo.

TERASAWA JÚNIOR, F. Seleção recorrente com endogamia em duas populações de milho: Avaliação quantitativa e perspectivas para seleção de híbridos. Piracicaba, 1993. 169p. Dissertação (Mestrado) - Escola Superior de Agricultura 'Luiz de Queiroz", Universidade de São Paulo.

TORRES, L.A.M. Variâncias, covariâncias e correlações genéticas, fenotípicas e de ambiente no 'Composto Flint B' de milho (Zea mays L.). Viçosa, 1978. 46p. Dissertação (M.S.) - Universidade Federal de Viçosa.

TYAGI, A.P.; POKHARIYAL, G.P.; ODONGO, O.M. Correlation and path coefficient analysis for yield components and maturity traits in maize (Zea moys L.). Maydica, v.33, n.2, p.109-119, 1988.

VALOIS, A.C.C.; MIRANDA FILHO, J.B. Comparação entre métodos de seleção em milho cv. Centralmex. Pesquisa Agropecuária Brasileira, v.19, p.479-488, 1984.

VENCOVSKY, R. Herança quantitativa. In: PATERNIANI, E. \& VIEGAS, G.P. Melhoramento e produção de milho, $2^{\text {a }}$ ed., Campinas, Fundação Cargill, 1987, v.1, cap.5, p.137-216. 
VENCOVSKY, R.; BARRIGA, P. Genética biométrica no fitomelhoramento, Ribeirão Preto: Sociedade Brasileira de Genética, 1992. 496p.

VENCOVSKY, R.; MIRANDA FILHO, J.B.; SOUZA JÚNIOR, C.L. Quantitative genetics and corn breeding in Brazil. In: INTERNATIONAL CONFERENCE ON QUANTITATIVE GENETICS, 2., Raleigh, 1987. Proceedings. Sunderland: Sinauer Associates, 1988. p.465-477.

VIANNA, R.T. Correlações genéticas e capacidade geral de combinação em linhagens endogâmicas de milho (Zea mays L.) Viçosa, 1977. 72p. Dissertação (M.S.) Universidade Federal de Viçosa.

VIANNA, R.T.; GAMA, E.E.G.; NASPOLINI FLLHO, V.; MORO, J.R.; VENCOVSKY, R. Inbreeding depression of several introduced populations of maize. Maydica, v.27, p.151-157, 1982.

WAHUA, T.A.; MLLER, D.A. Relative yield totals and yield components of intercropped sorghum and soybeans. Agronomy Journal, v.70, p. 287-291, 1978.

WALTERS, S.P.; RUSSELL, W.A.; LAMKEY, K.R.; WHITE, P.R. Performance and inbreeding depression between a synthetic and three improved populations of maize. Crop Science, v.31, n.1,p.80-83, 1991.

WILLIAMS, W. Genetical principles and plant breeding. Blackwell Publications, 1964. 504p.

WLLIS, J.H. Genetic analysis of inbreeding depression caused by chlorophyll-deficient lethals in Mimulus guttatus. Heredity, v.69, p. 562-572, 1992. 
WRIGHT, S. Coefficients of inbreeding and relationship. American Nature, v.56, p.330-8, 1922. 


\section{FIGURAS}



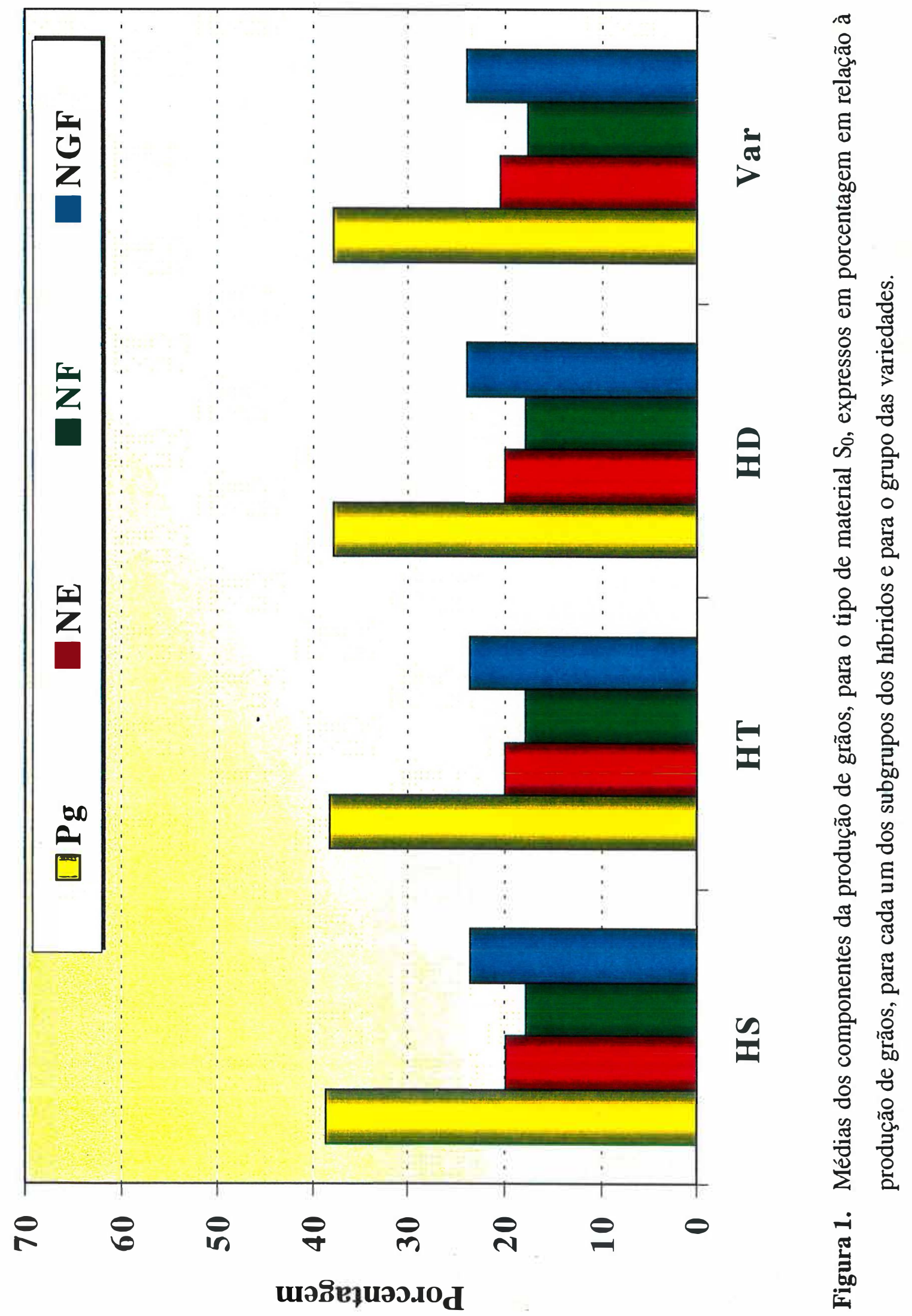

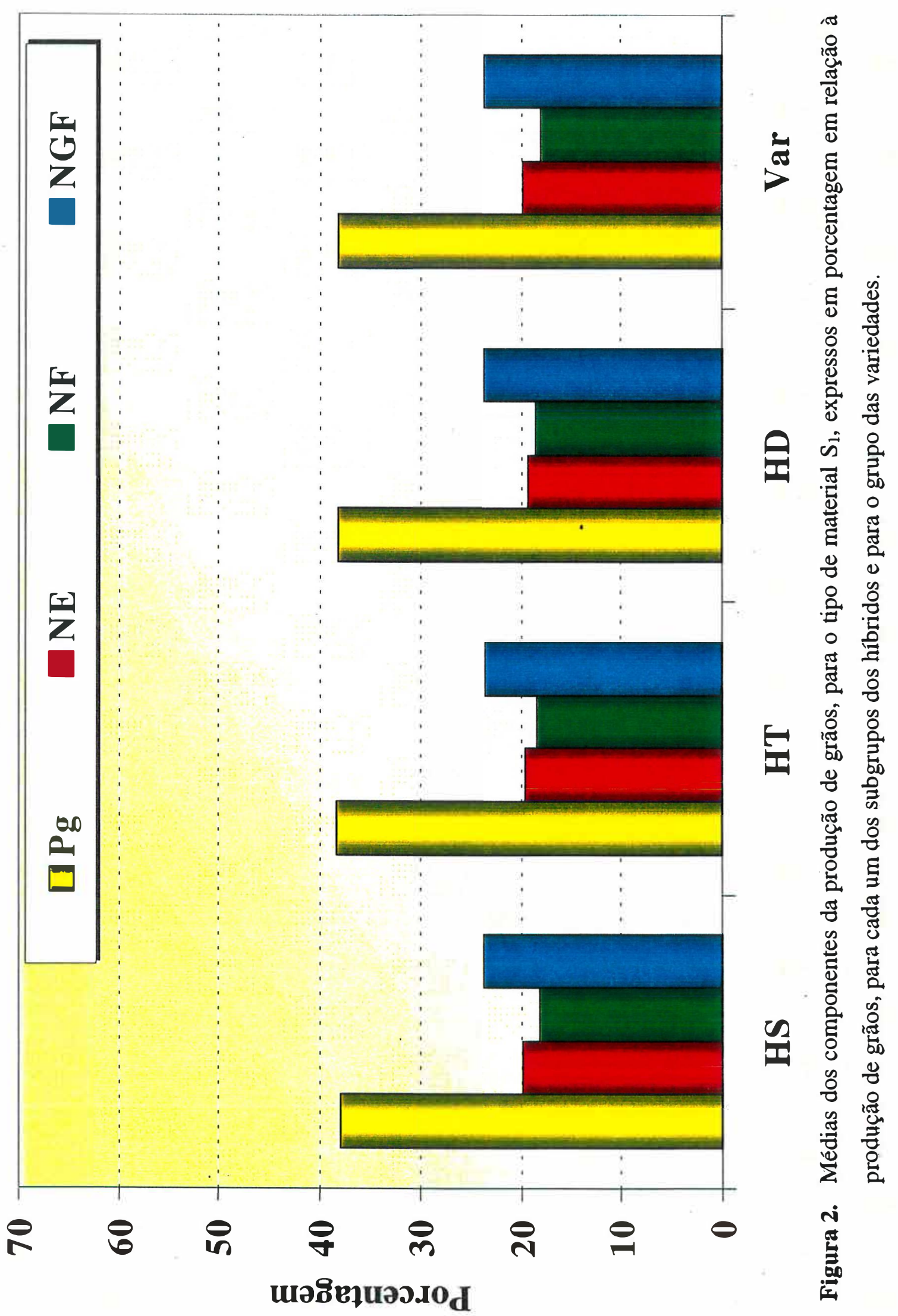


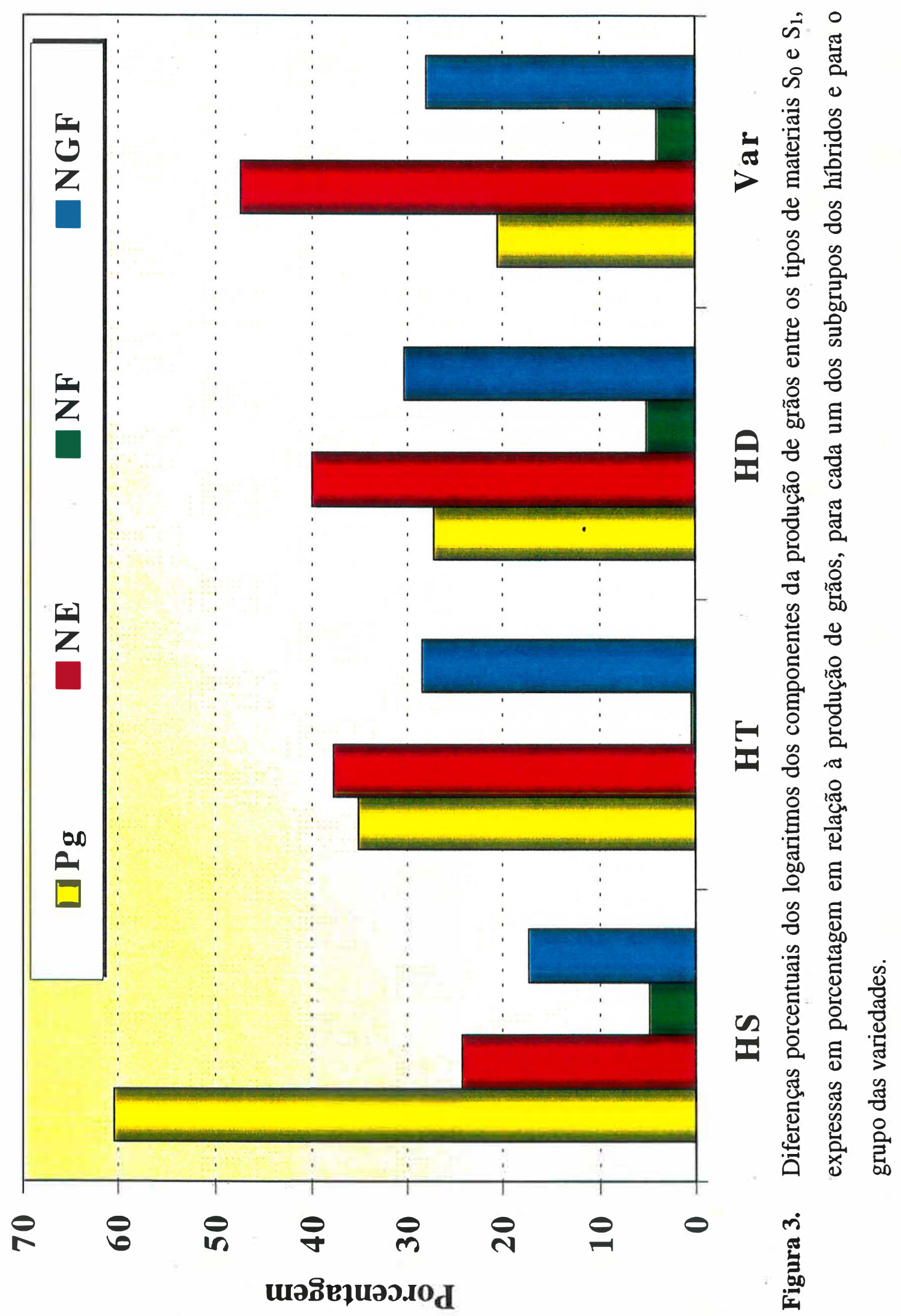


TABELAS 


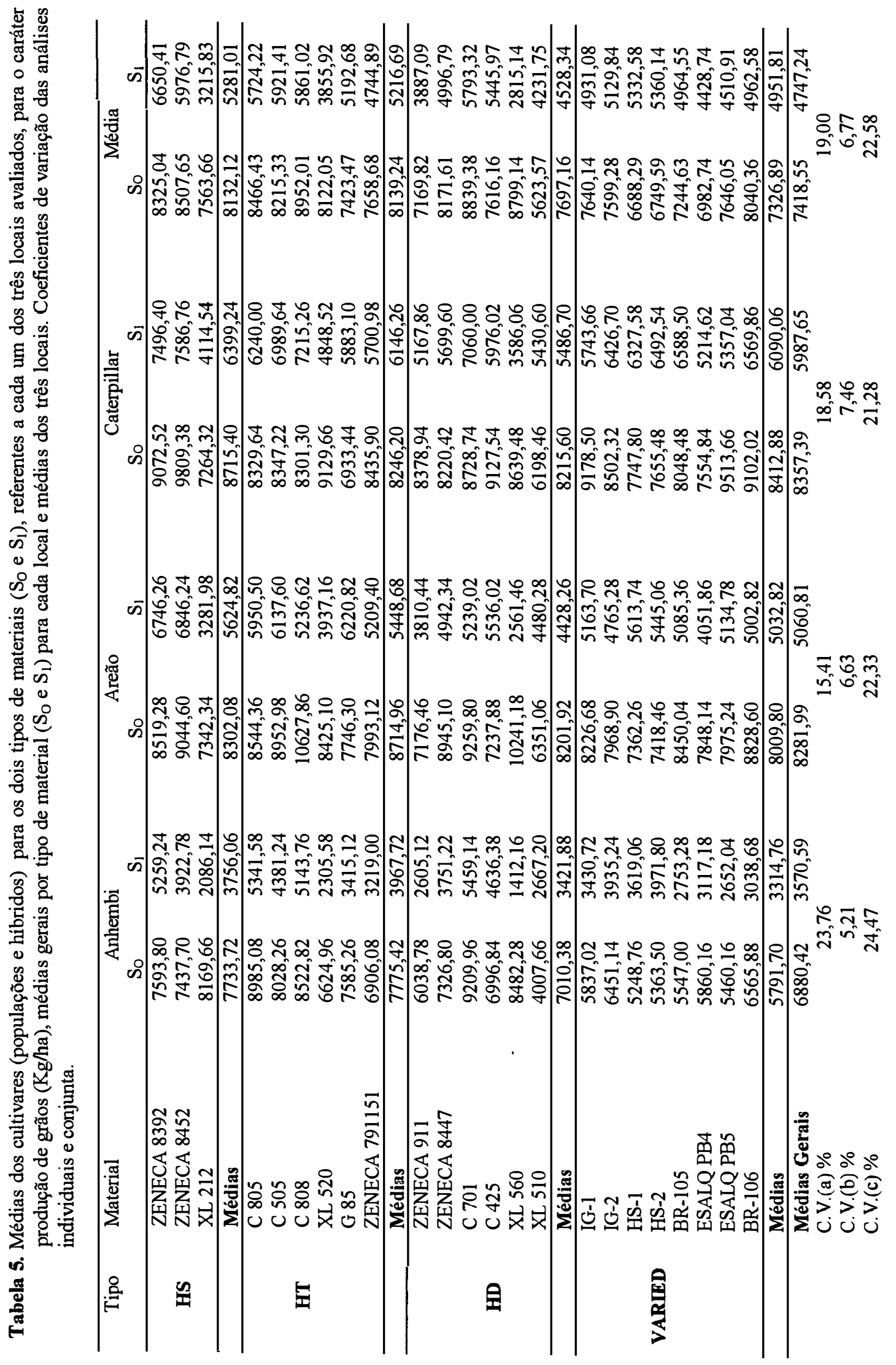




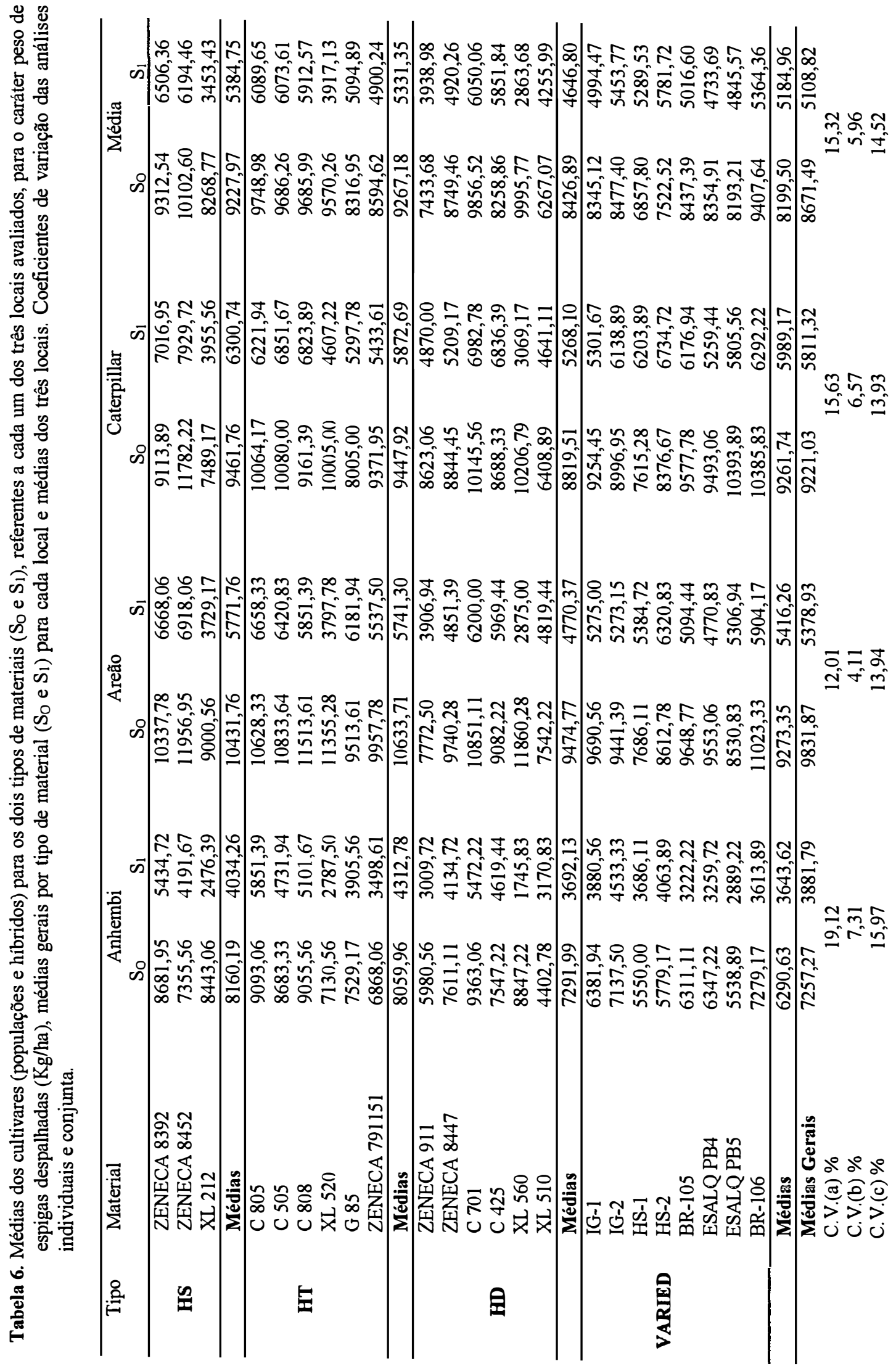




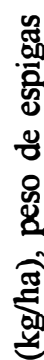

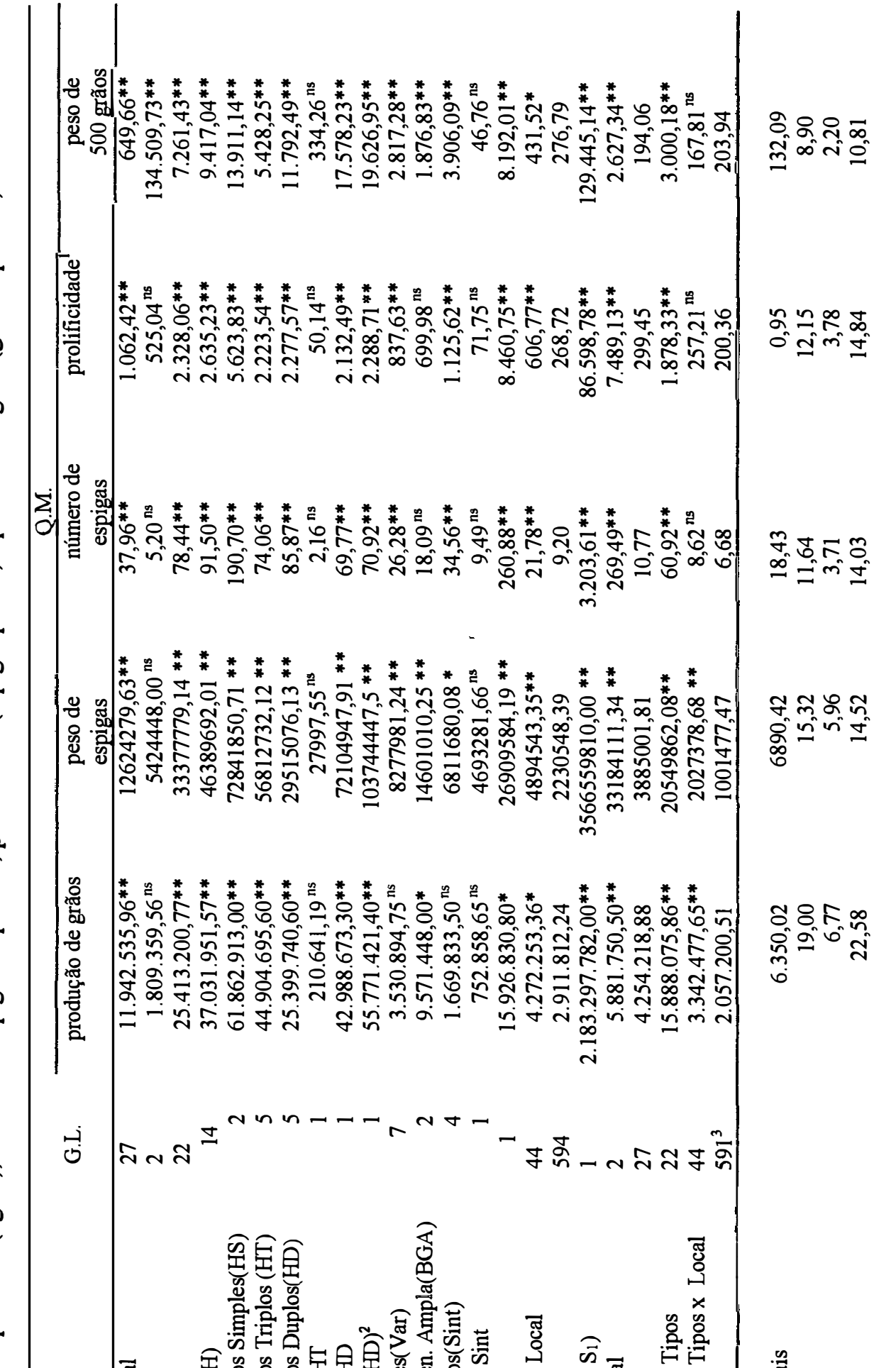

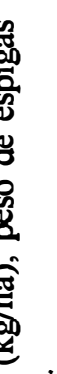

\section{(2)}

(2) 


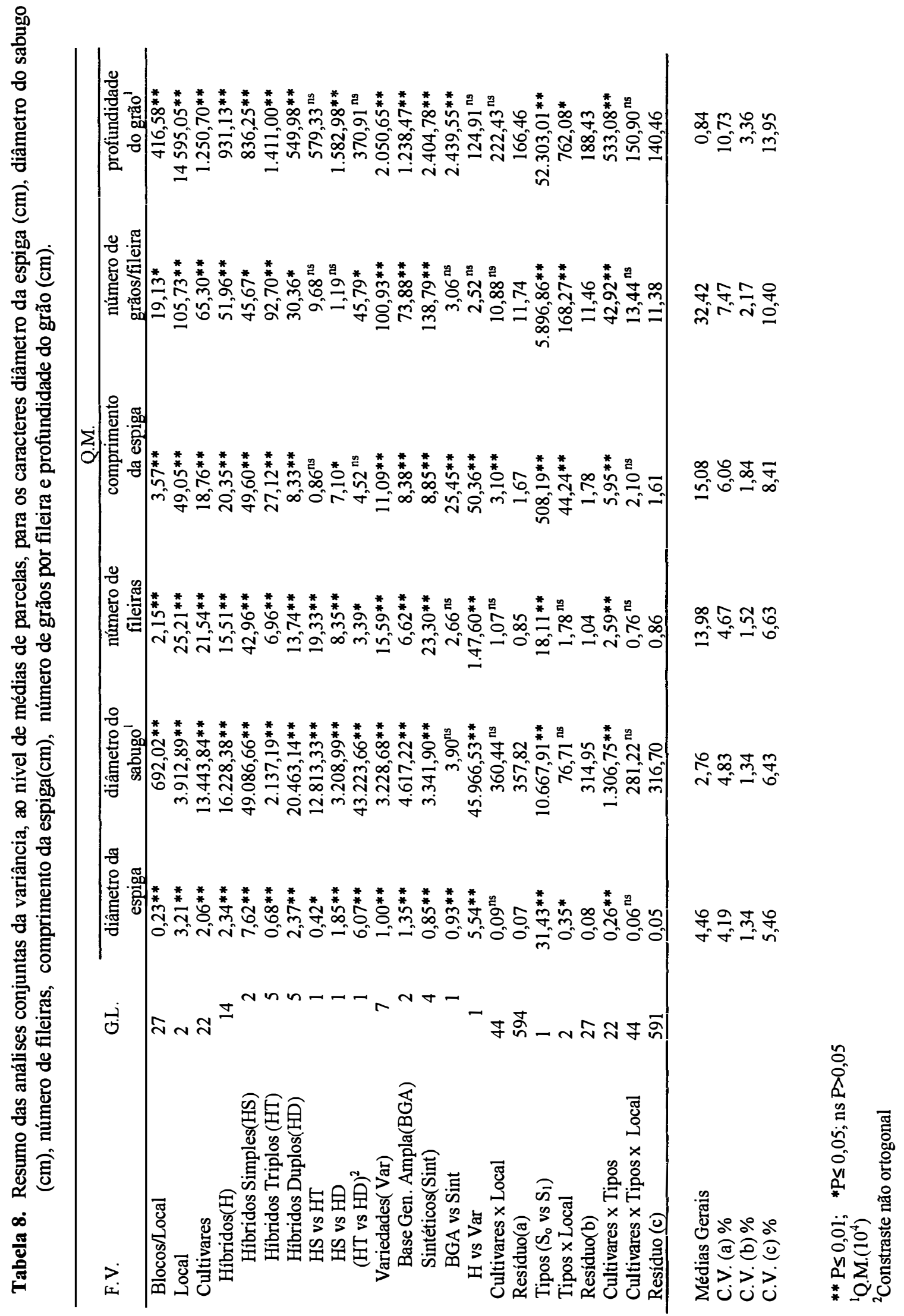




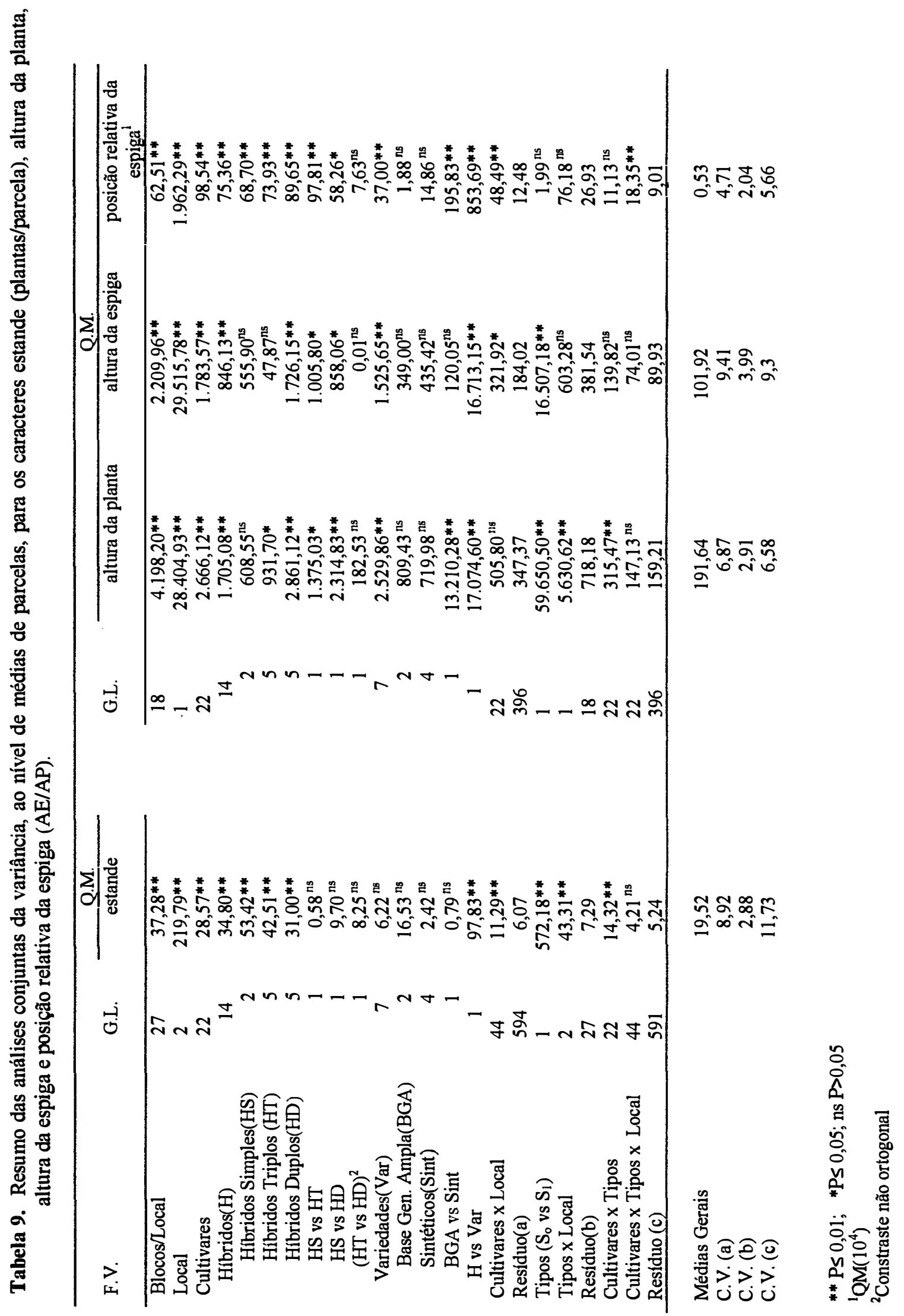




\begin{tabular}{|c|c|}
\hline 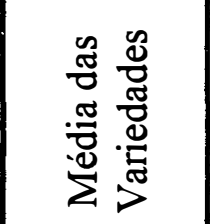 & 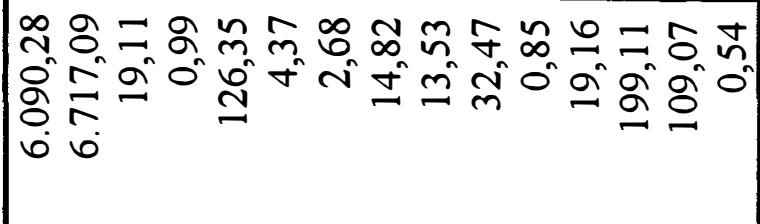 \\
\hline 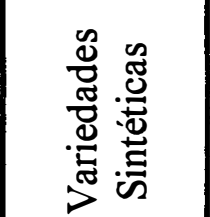 & 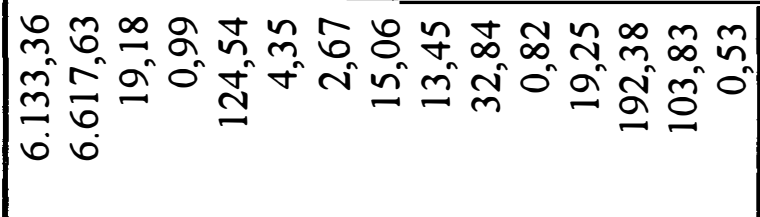 \\
\hline 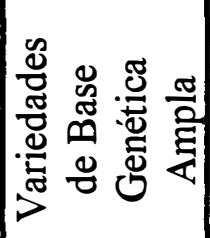 & 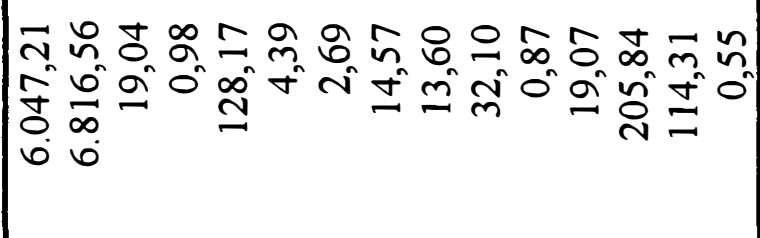 \\
\hline 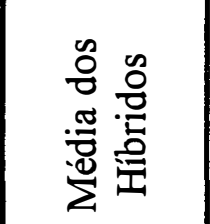 & 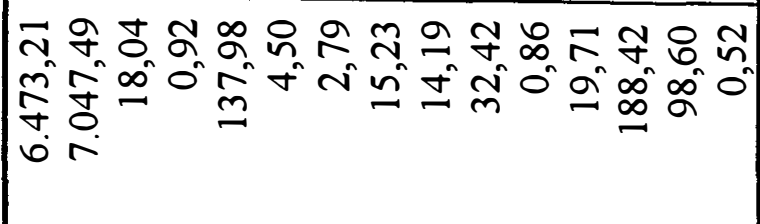 \\
\hline 量 & 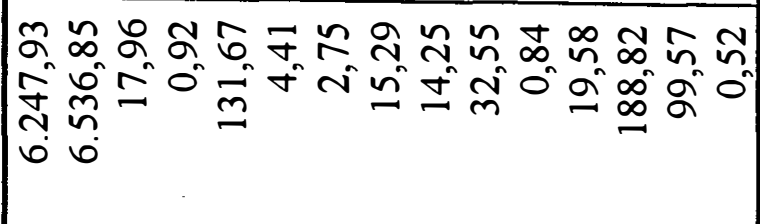 \\
\hline 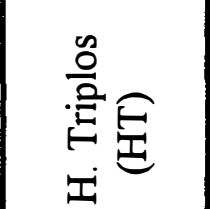 & 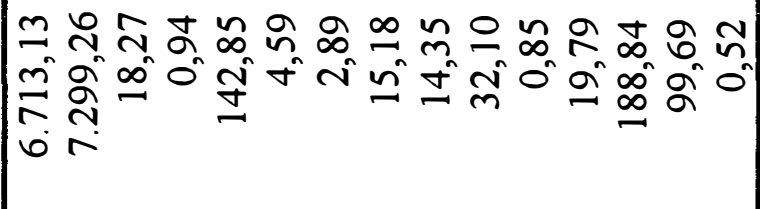 \\
\hline 兽忽 & 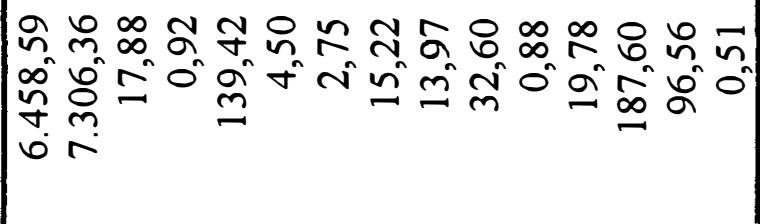 \\
\hline$\stackrel{\varrho}{\varrho}$ & 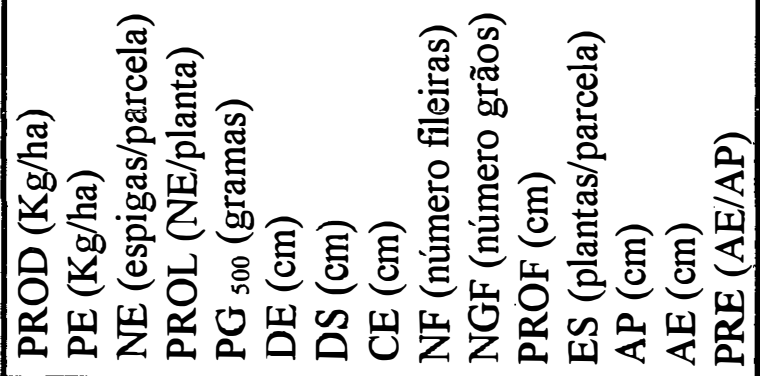 \\
\hline
\end{tabular}




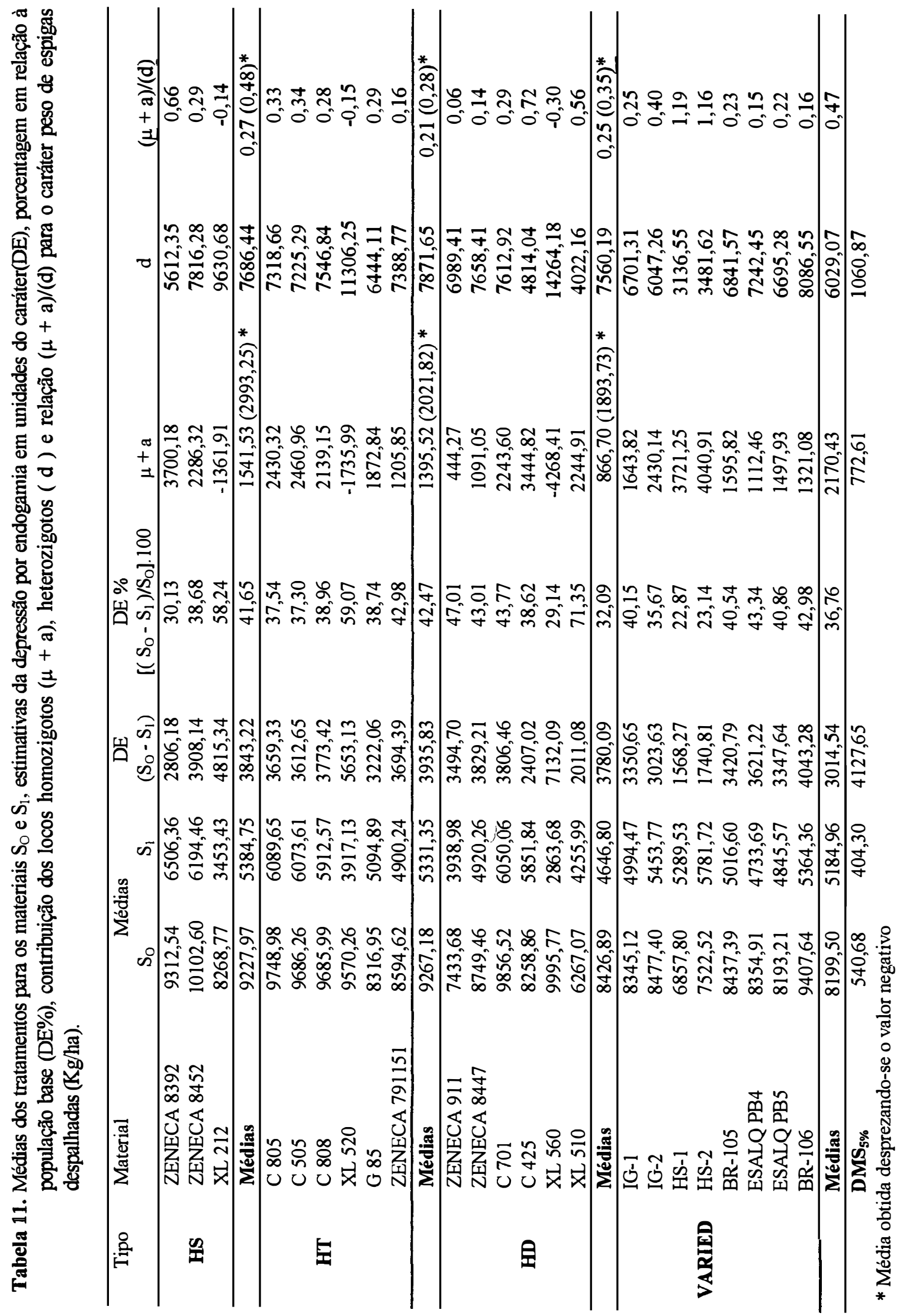




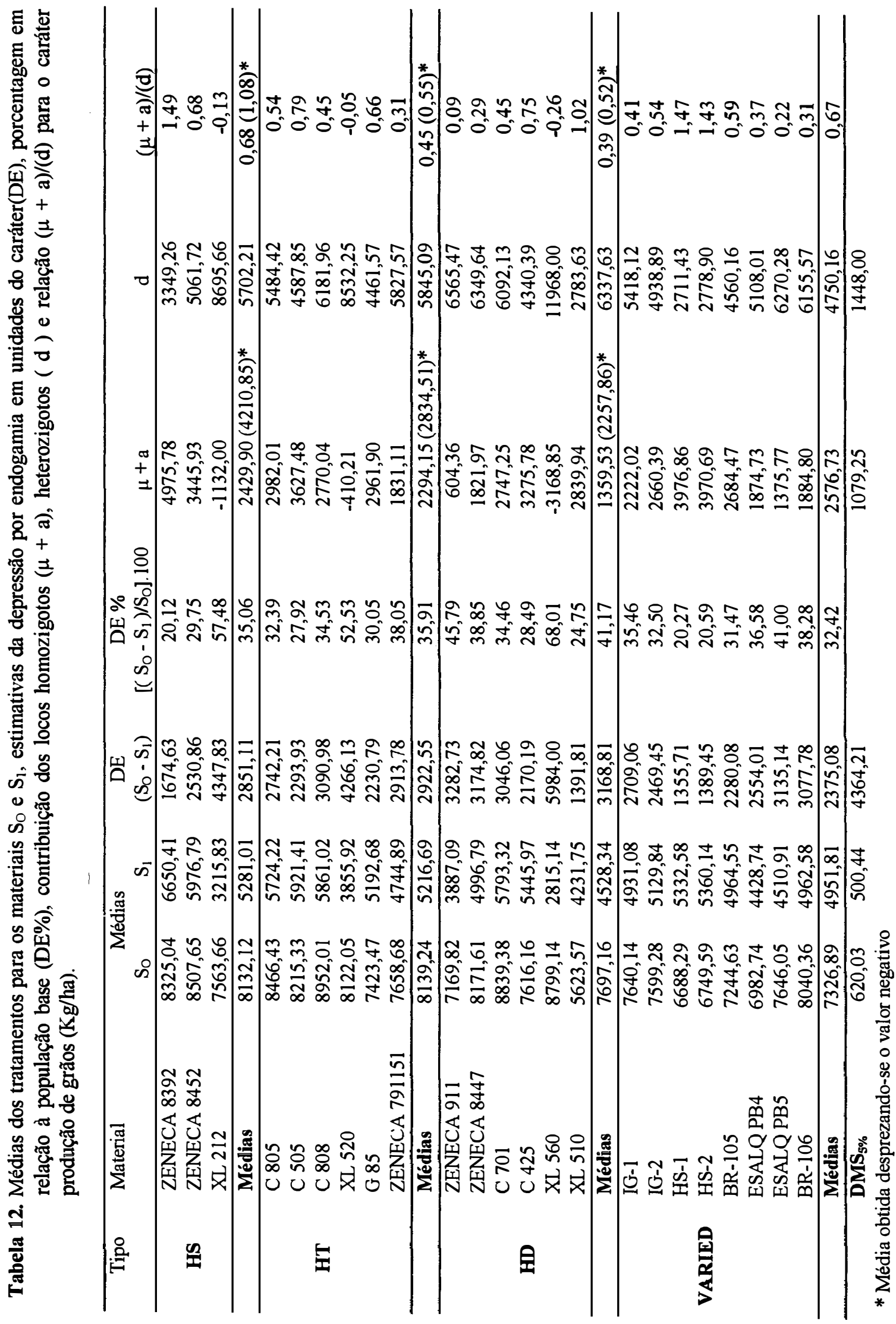




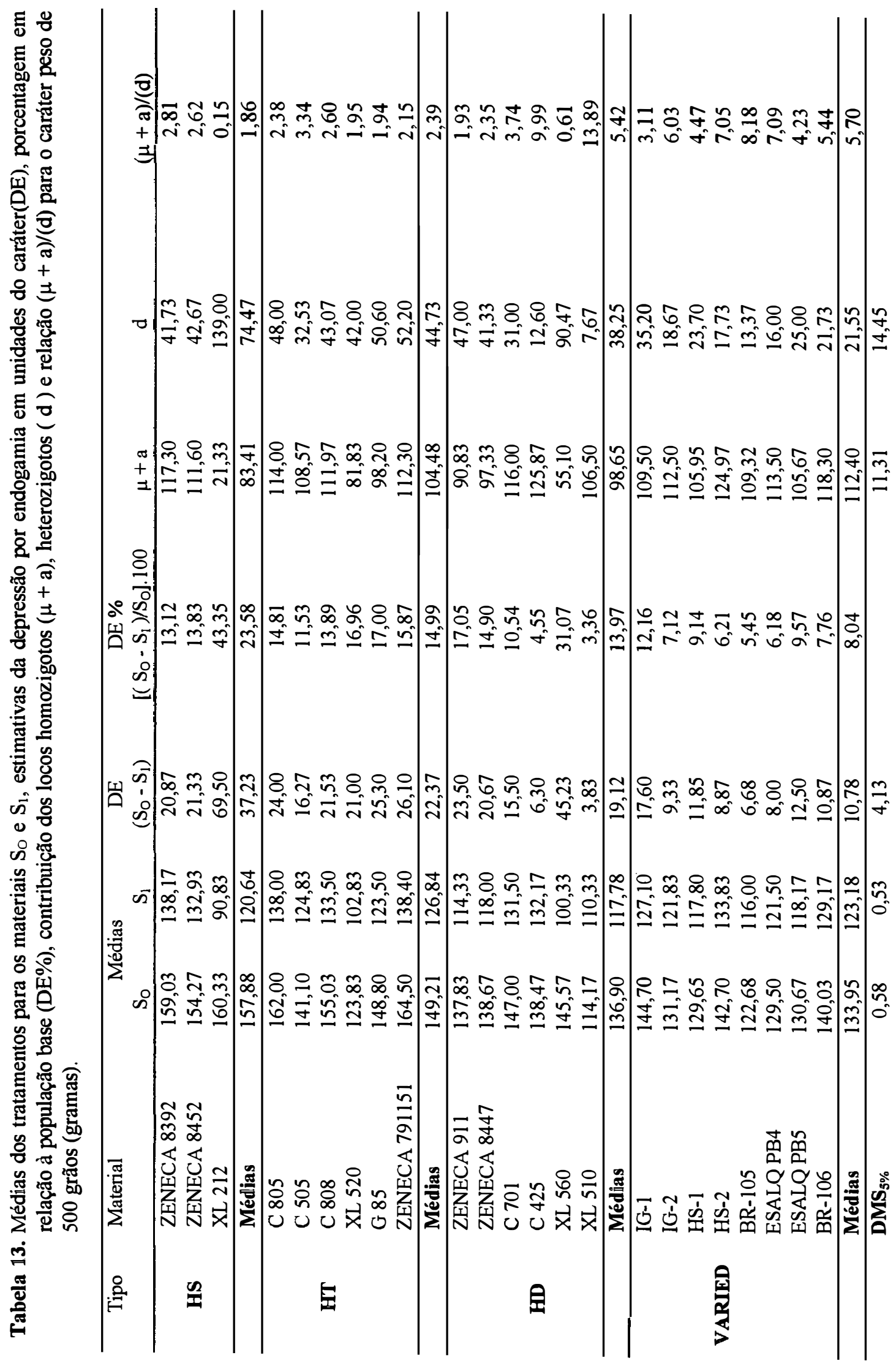




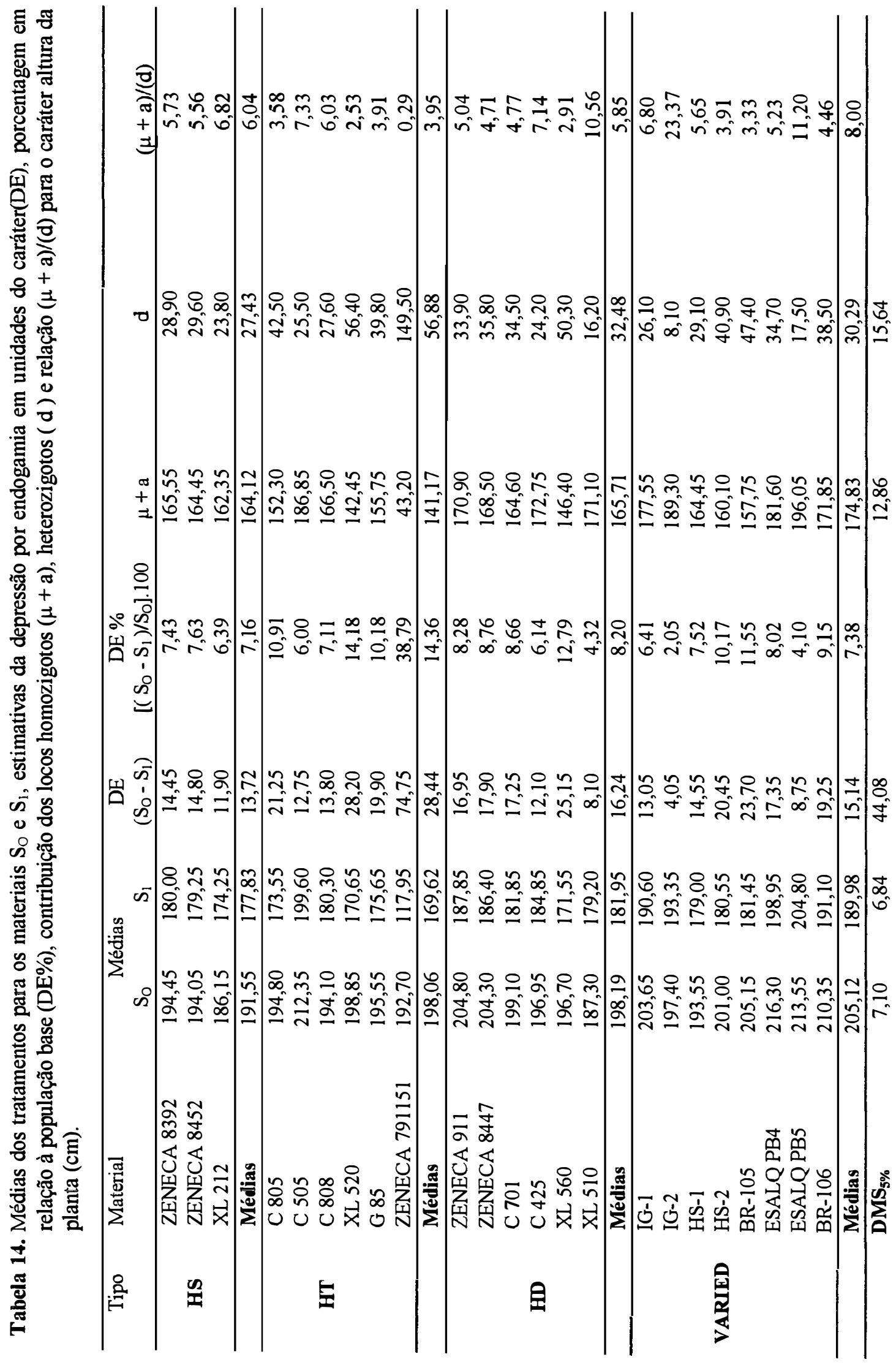




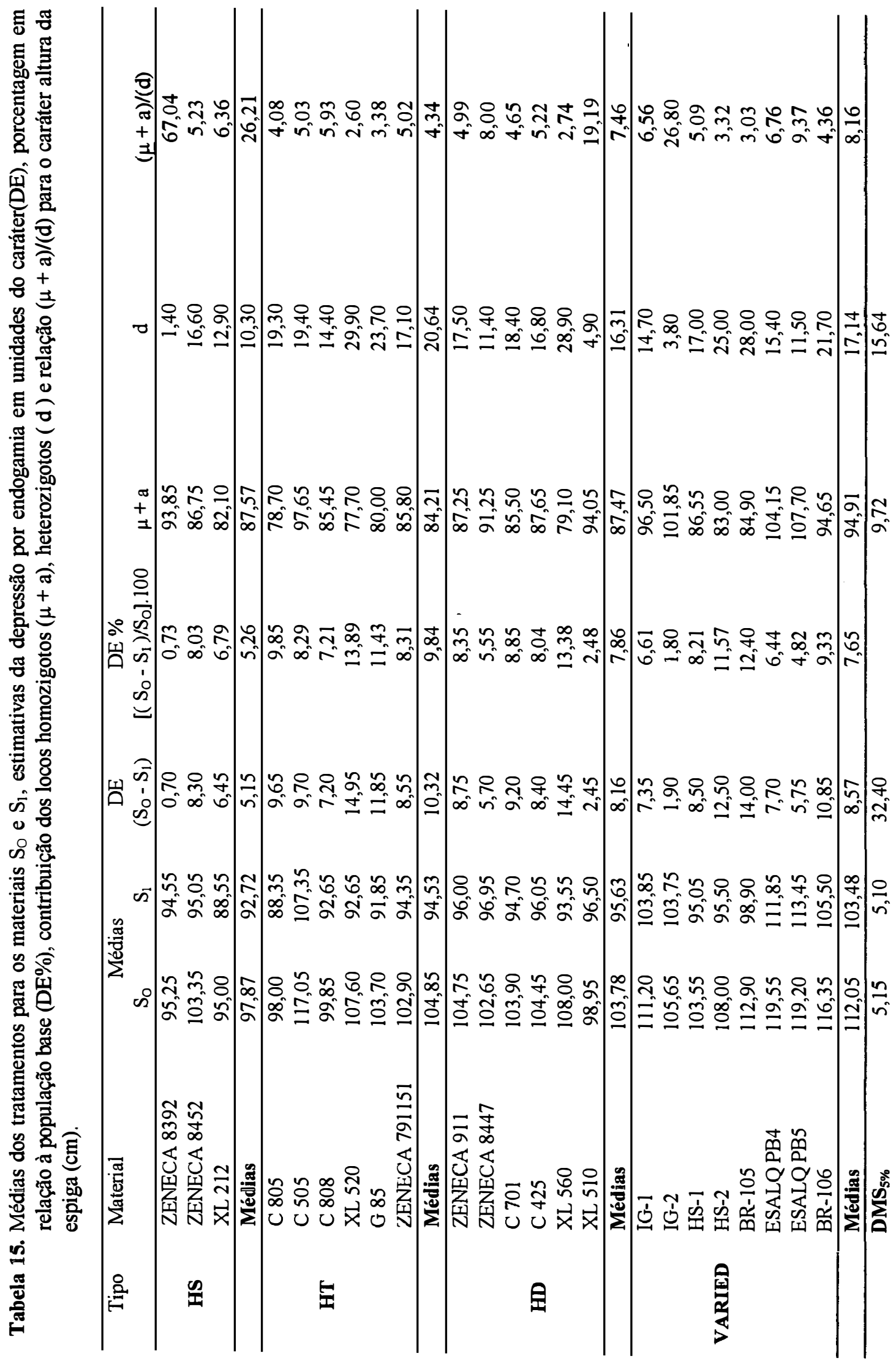




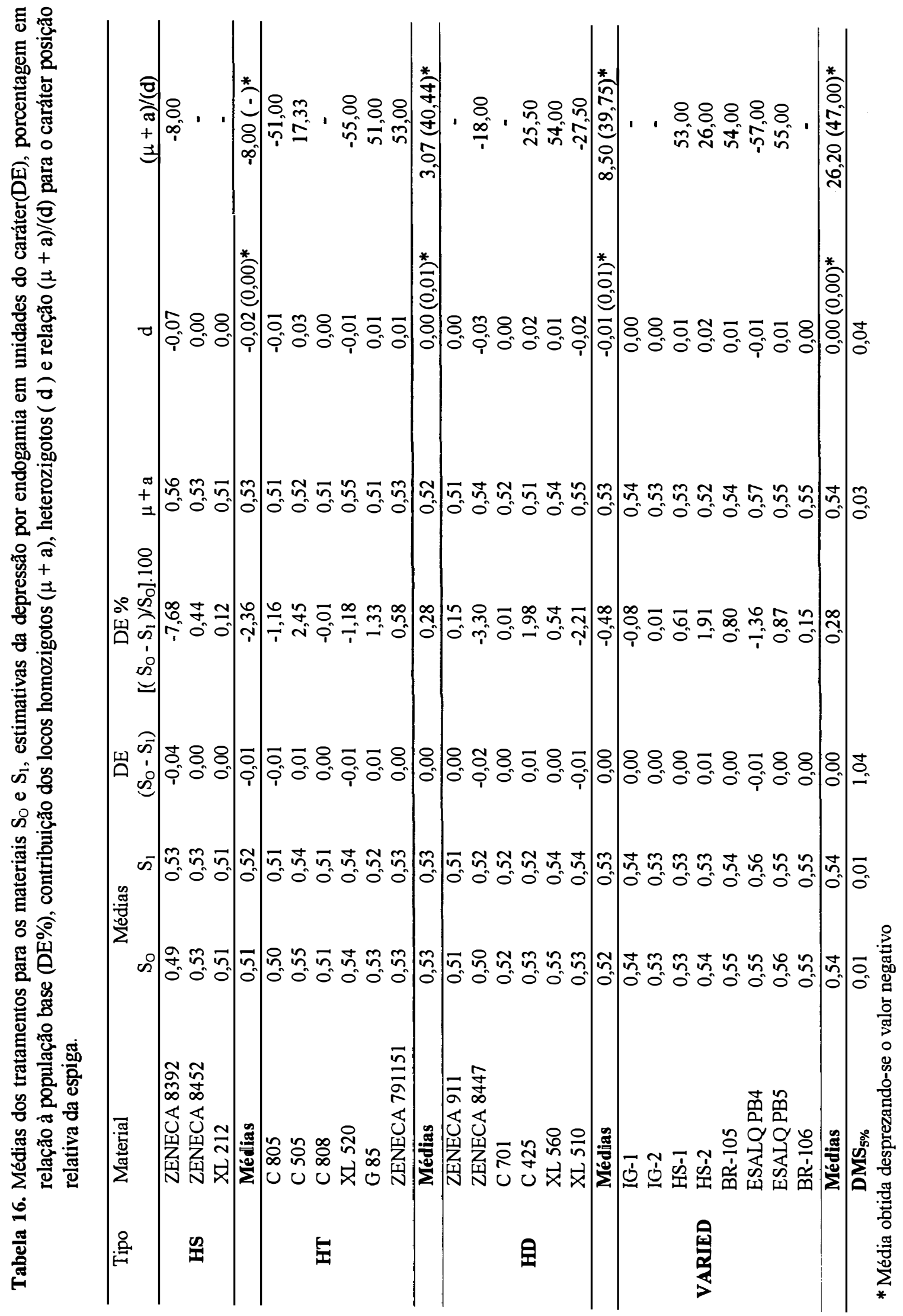




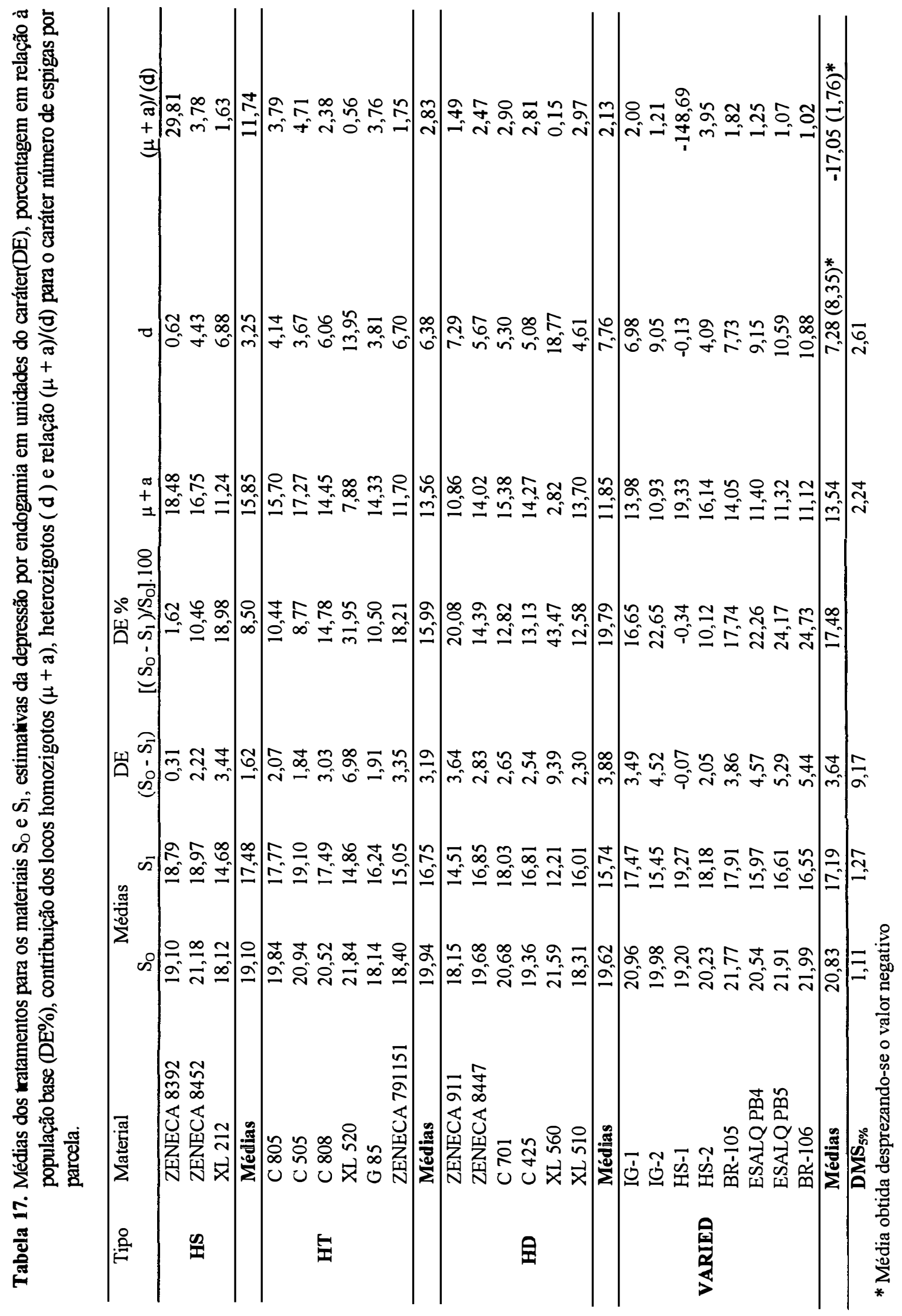




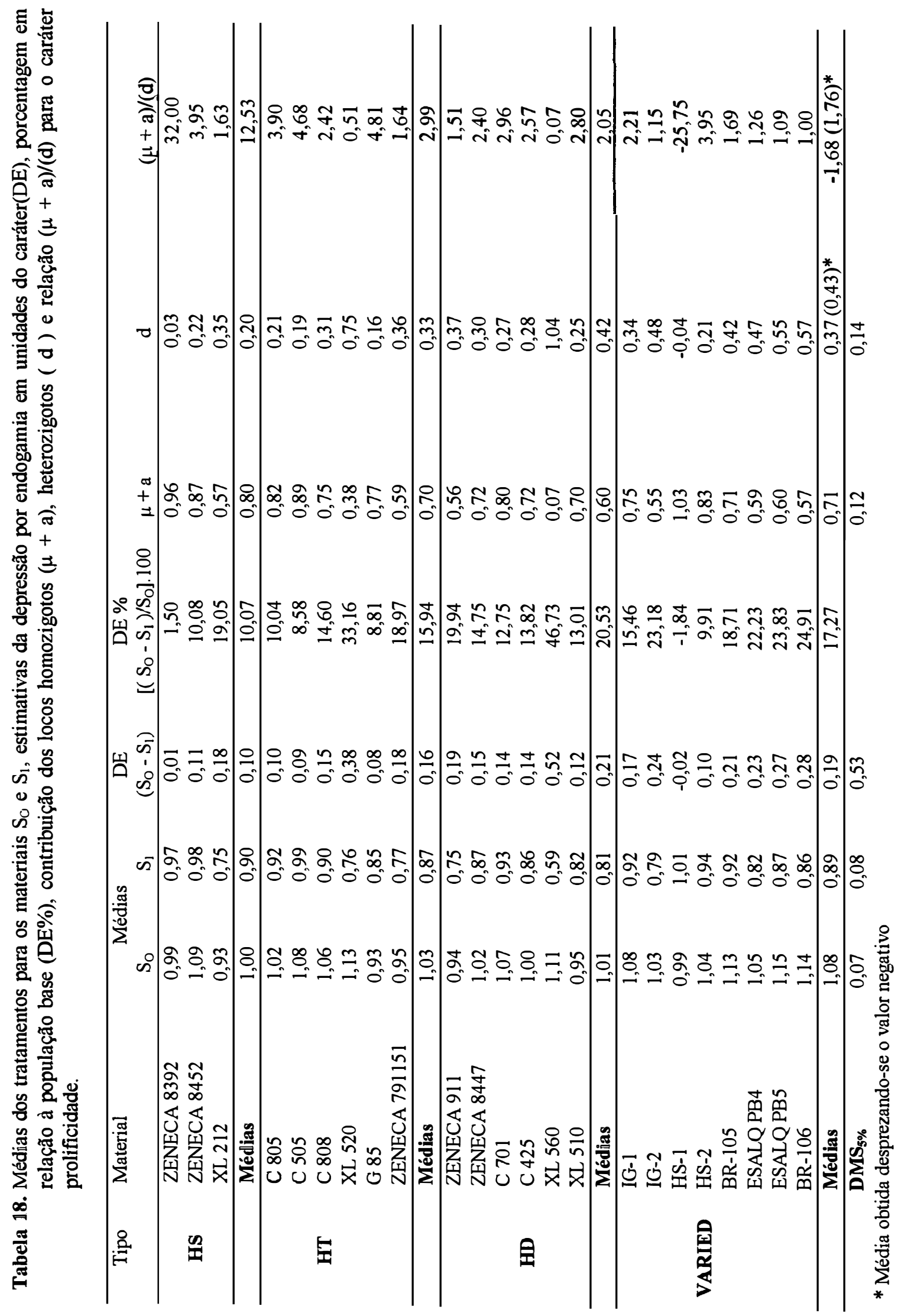




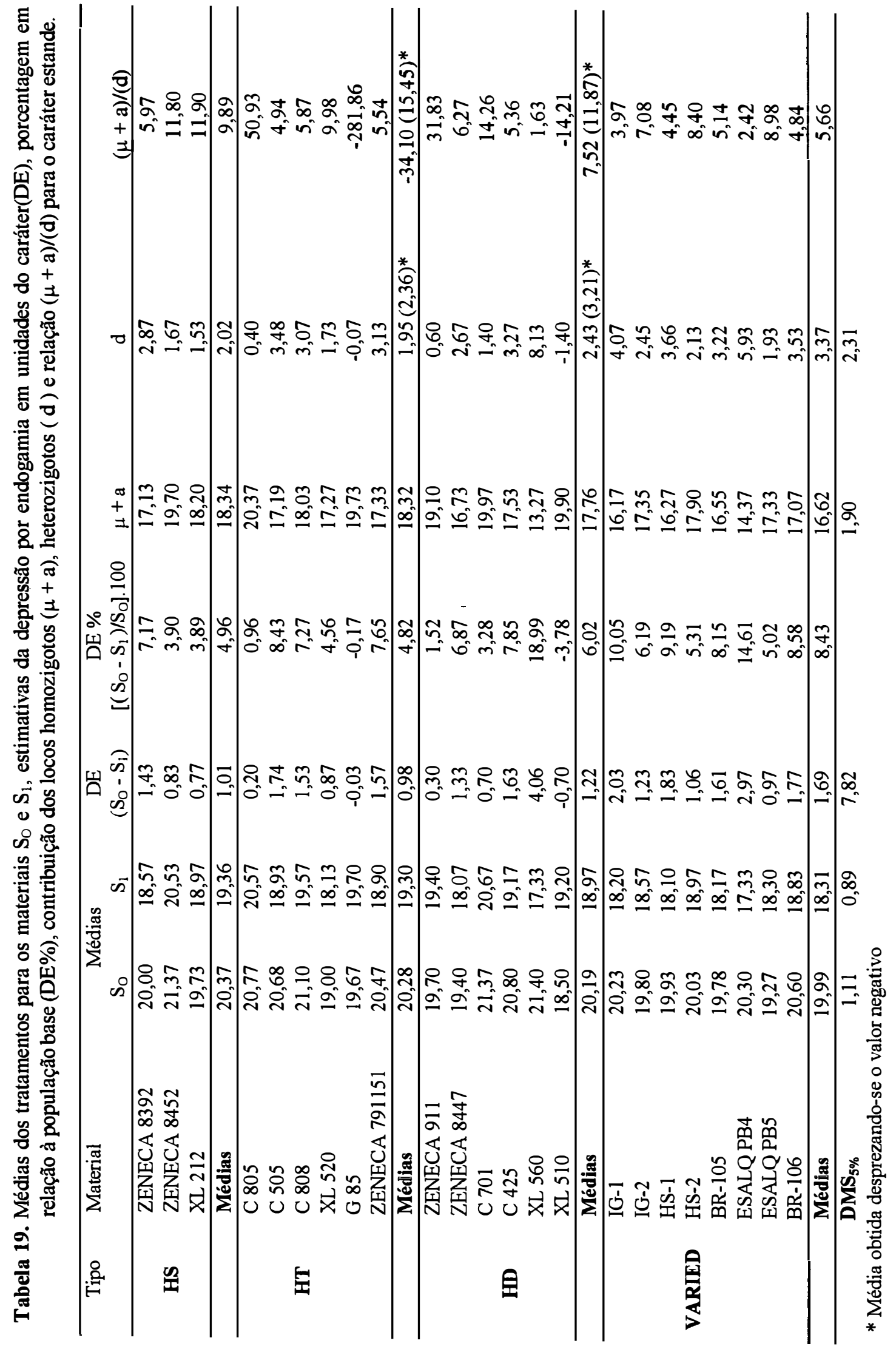




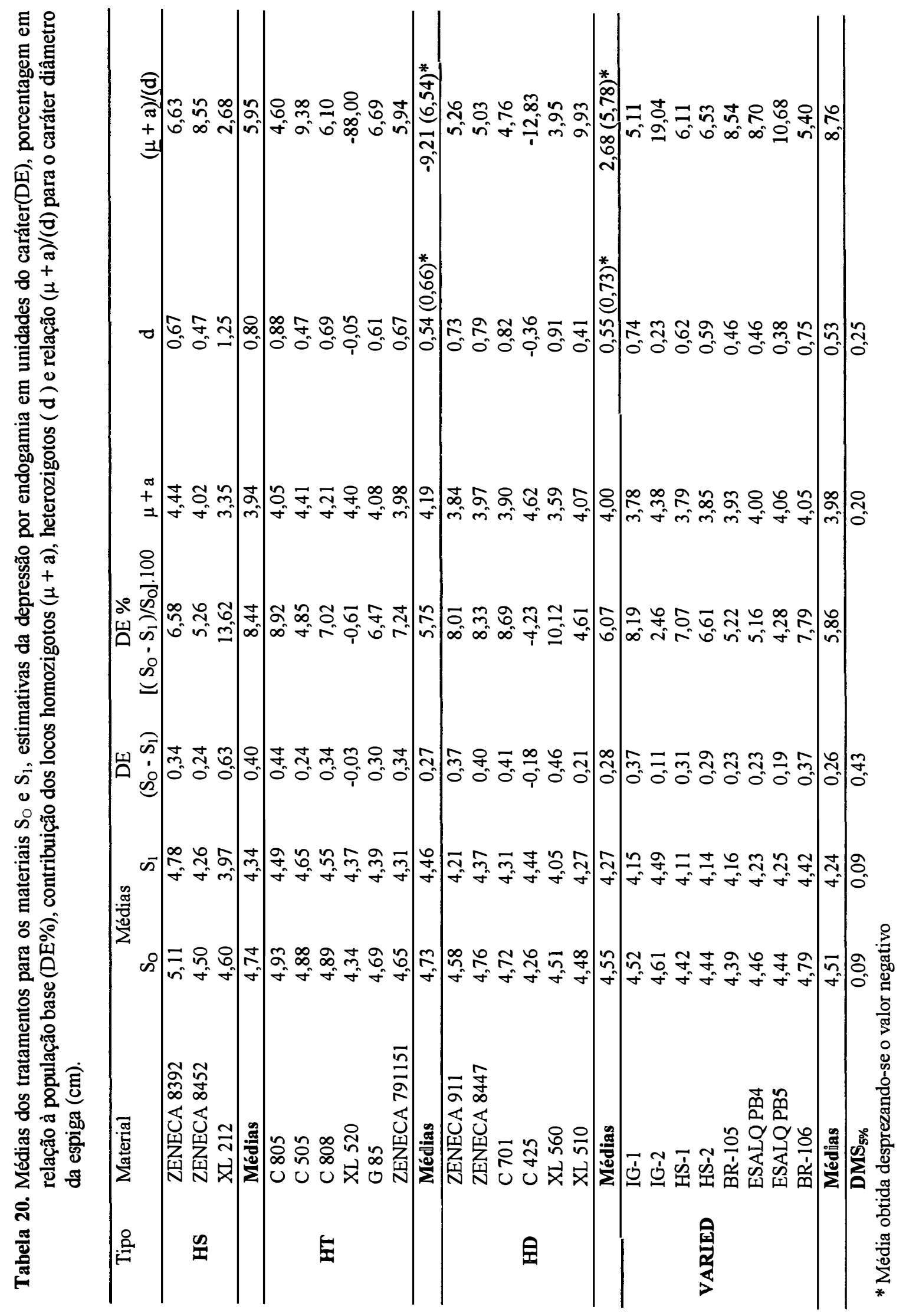




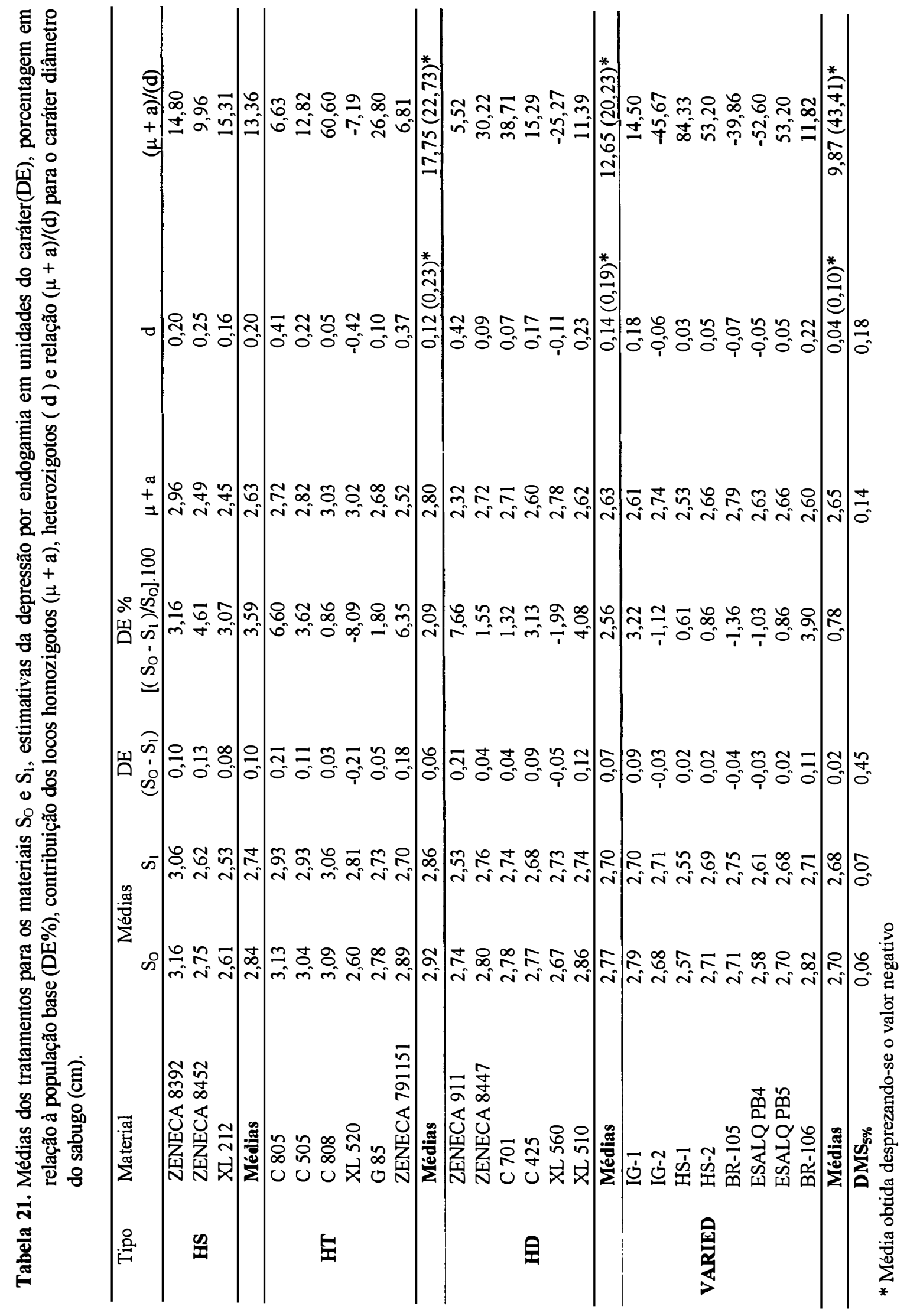




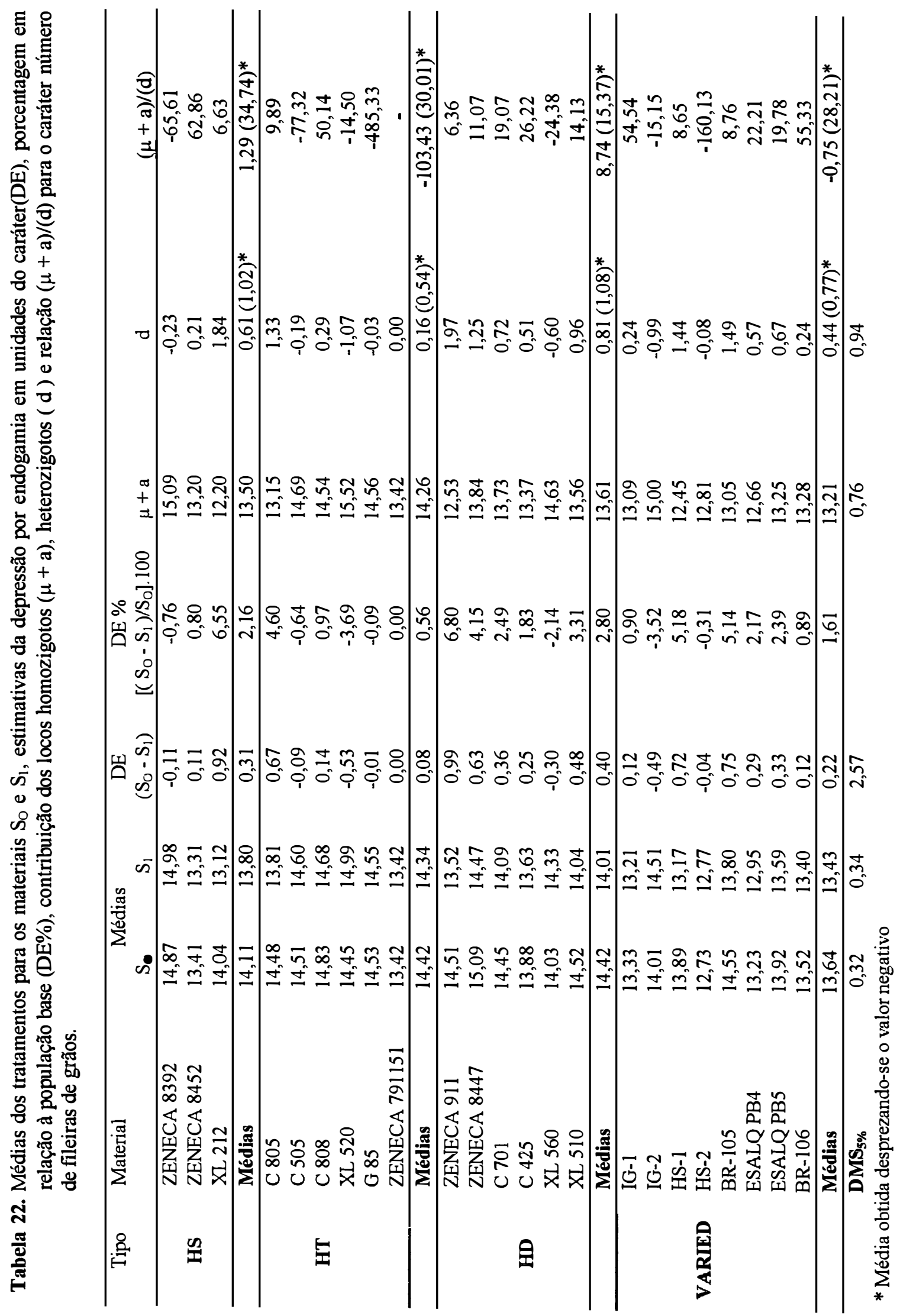




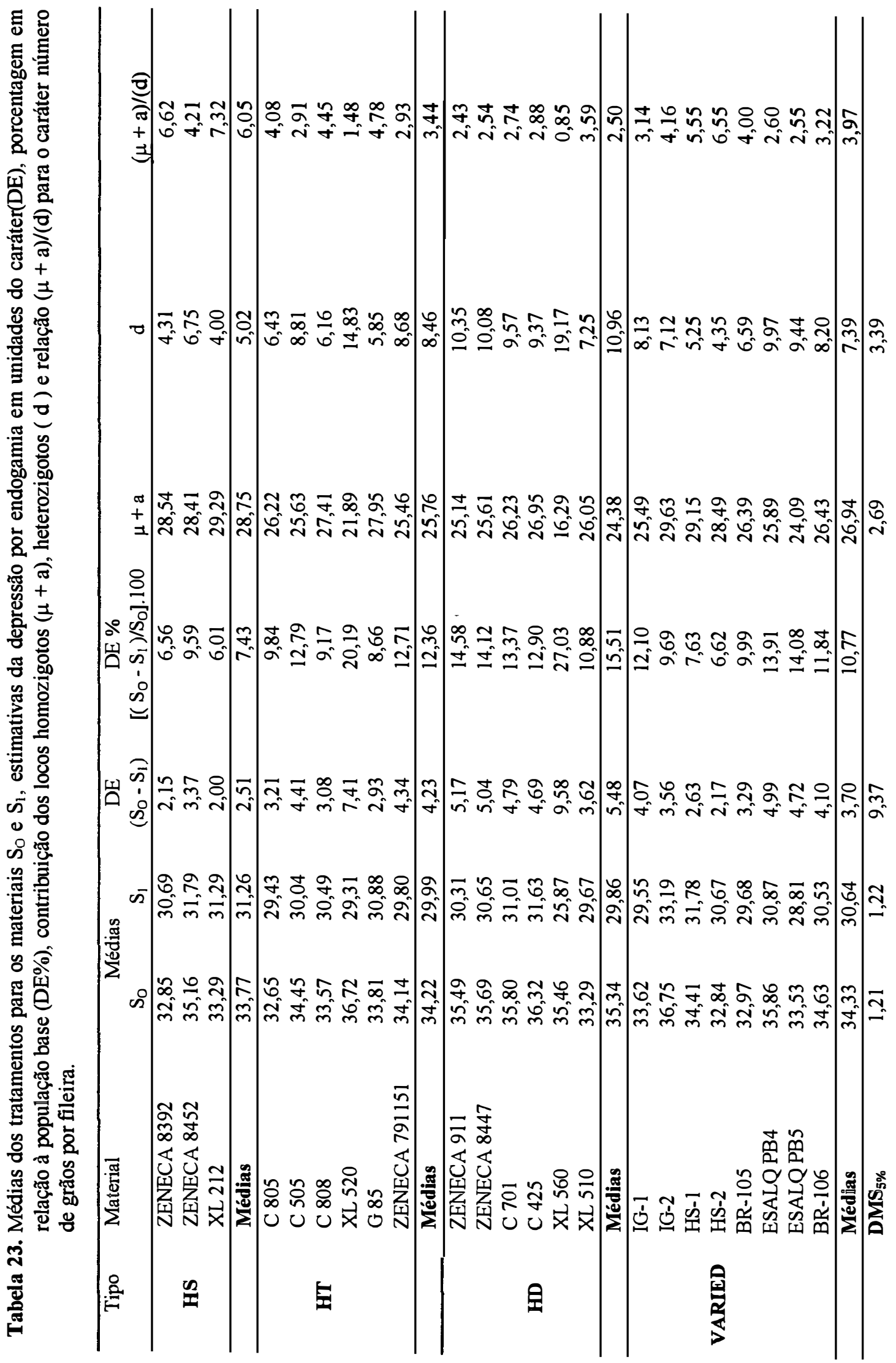




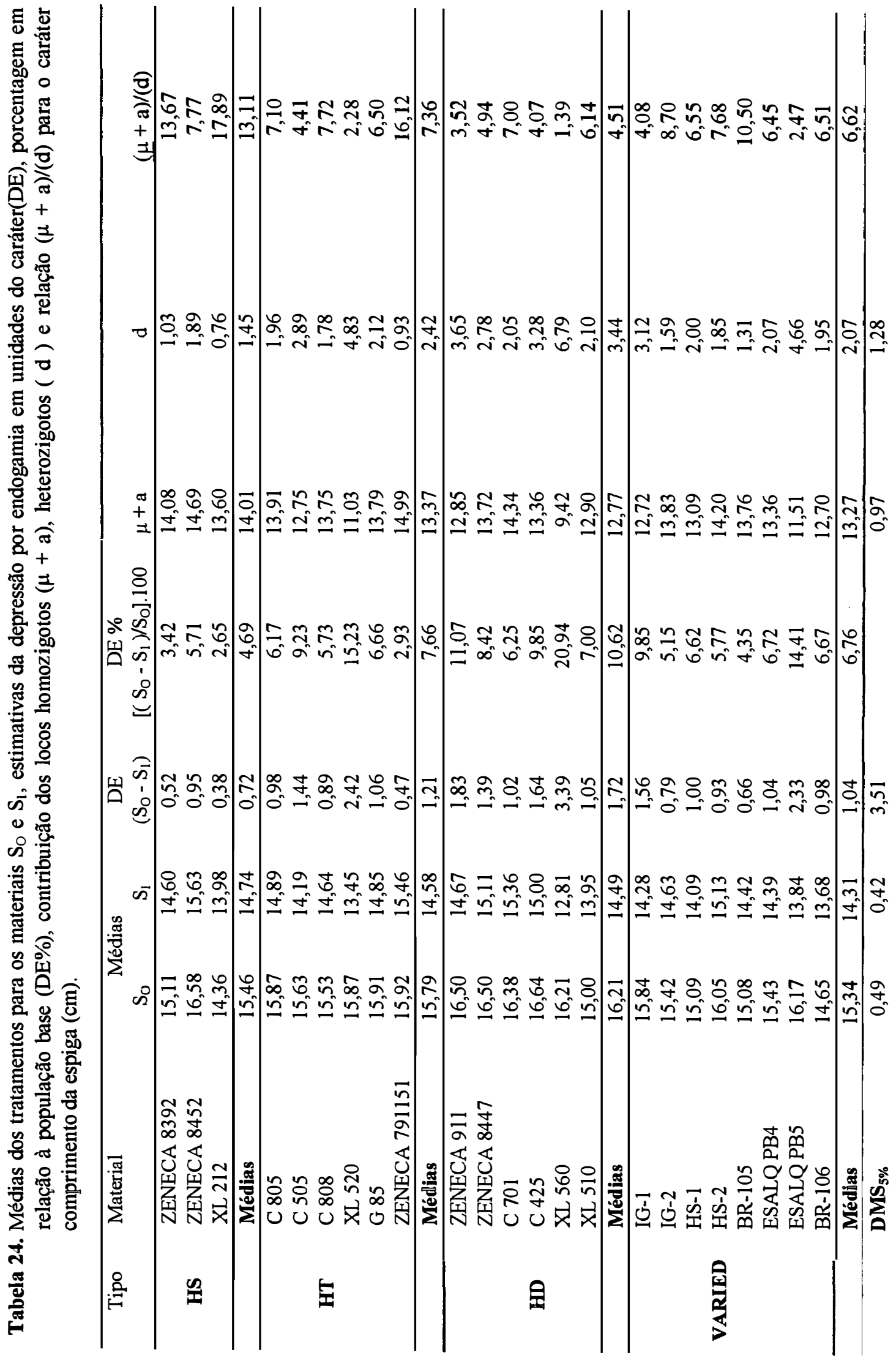




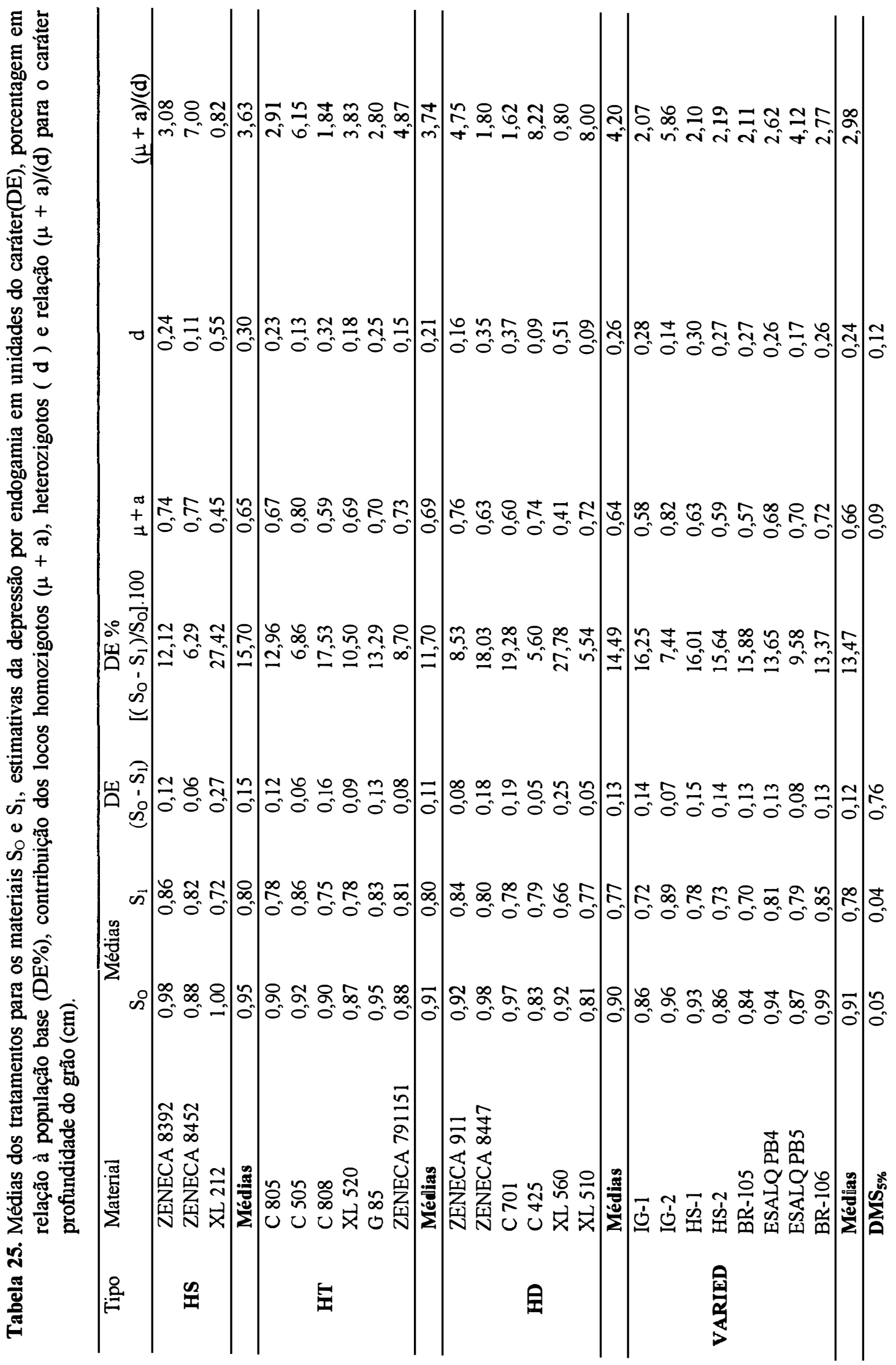




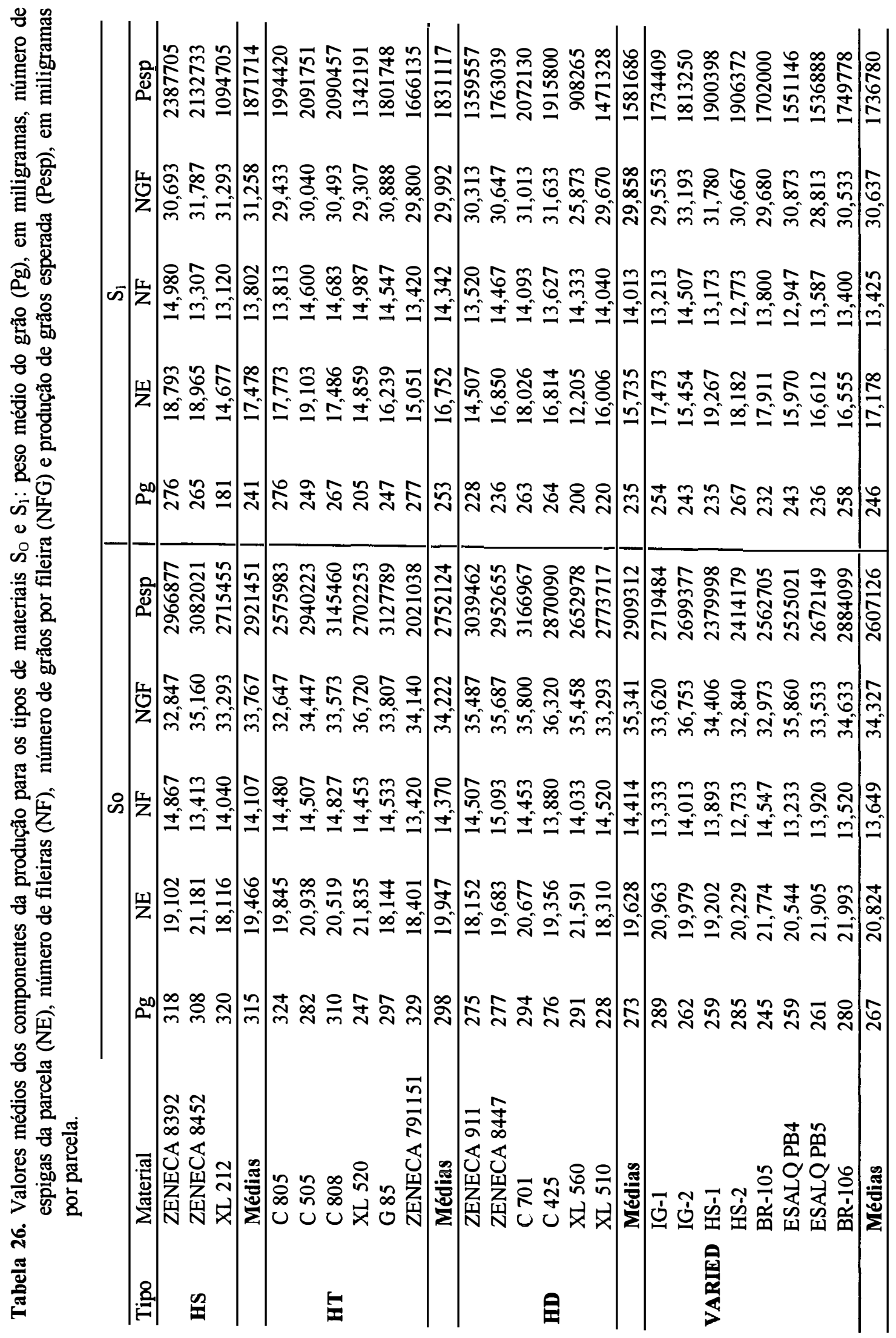




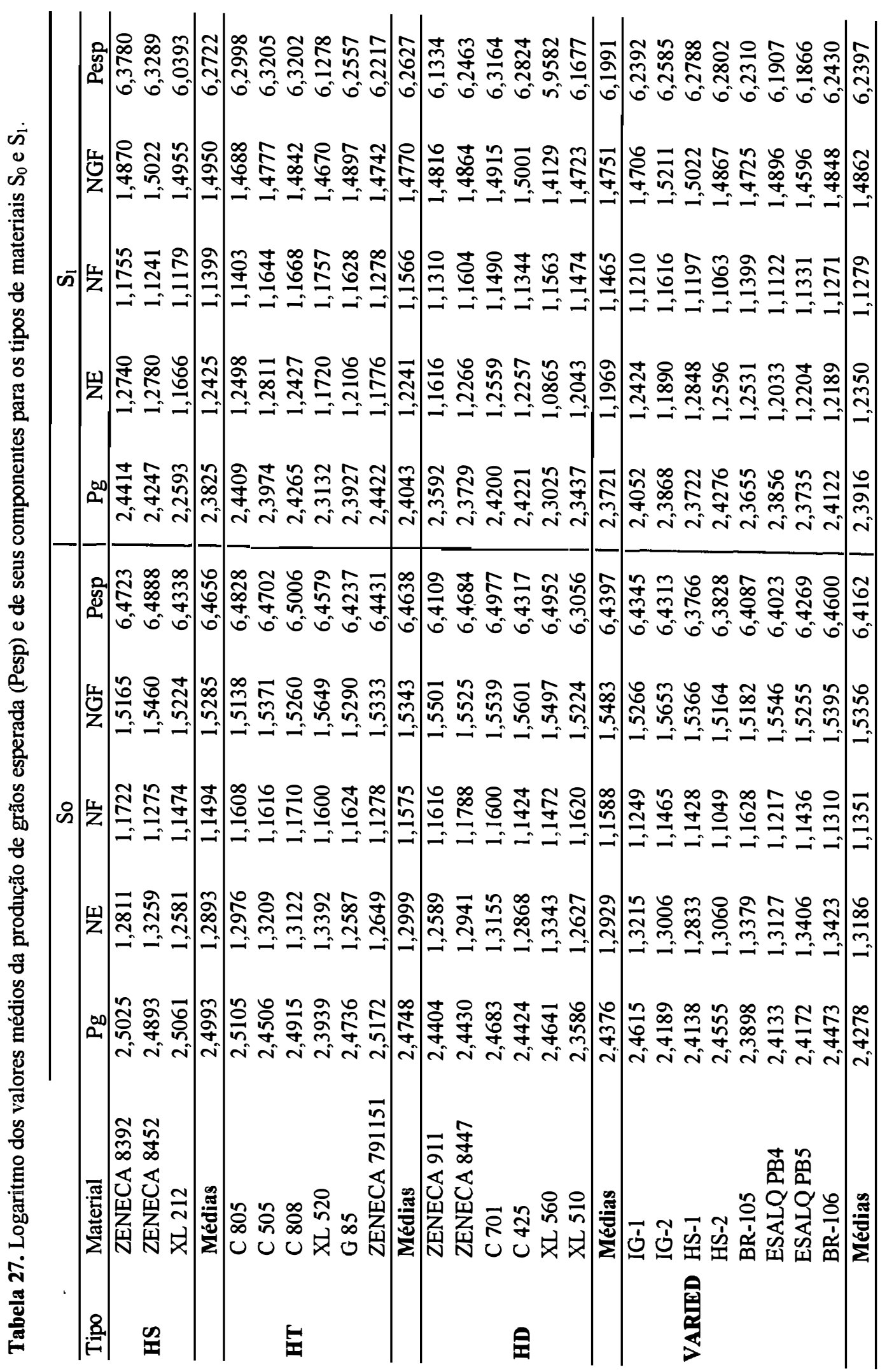




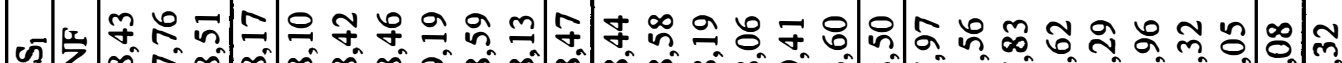
剀

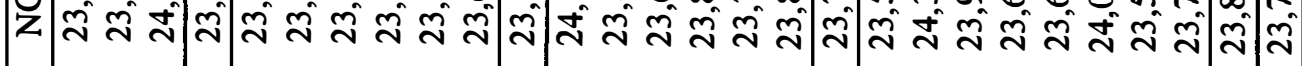

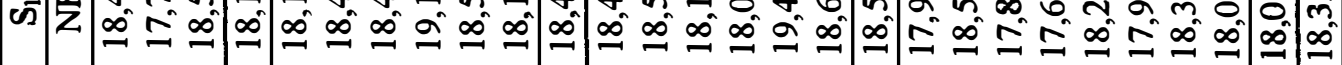

山ू.

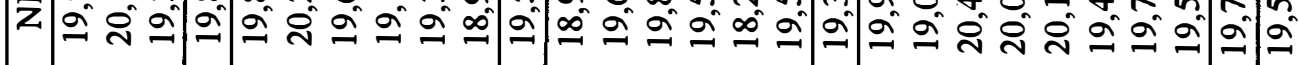

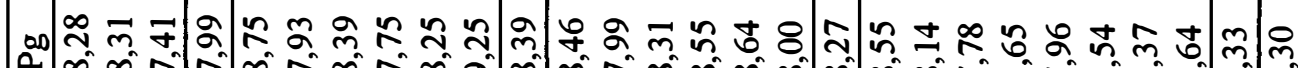

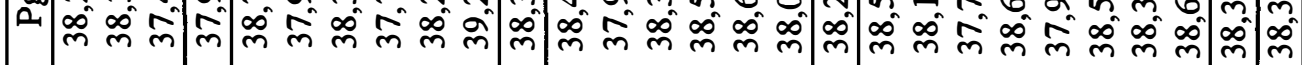

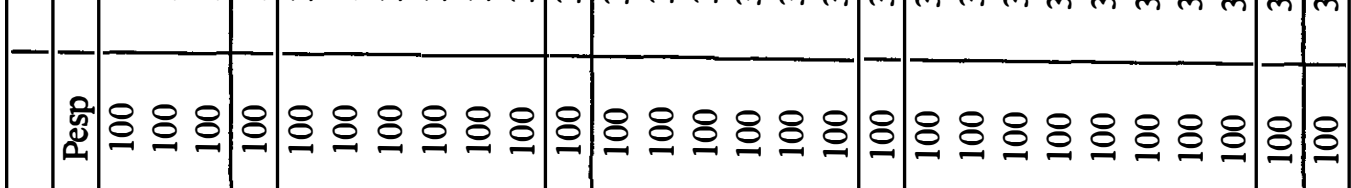

要

要

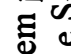

\%

늘

嵌

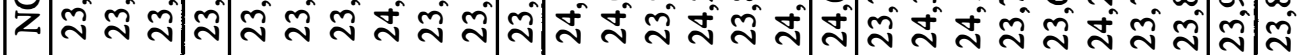

通

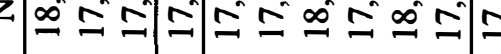

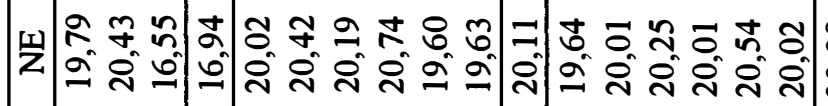

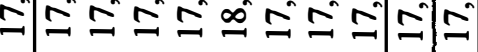

त्रे

"

哭

$\approx$

蛅

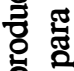

뭉

응

핼

영응

i

舟 ద

宽
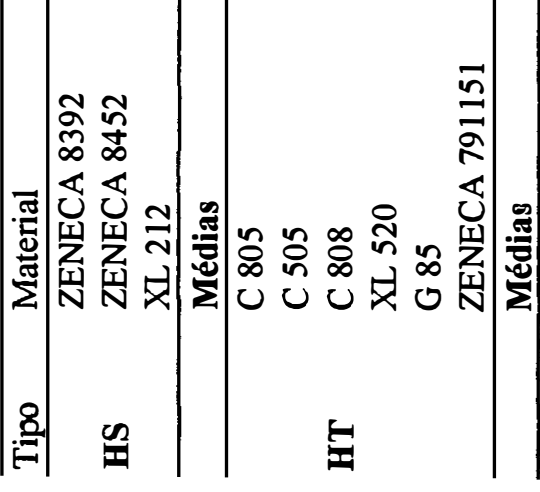

竞安

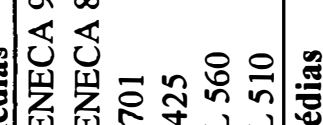

畏 웅 


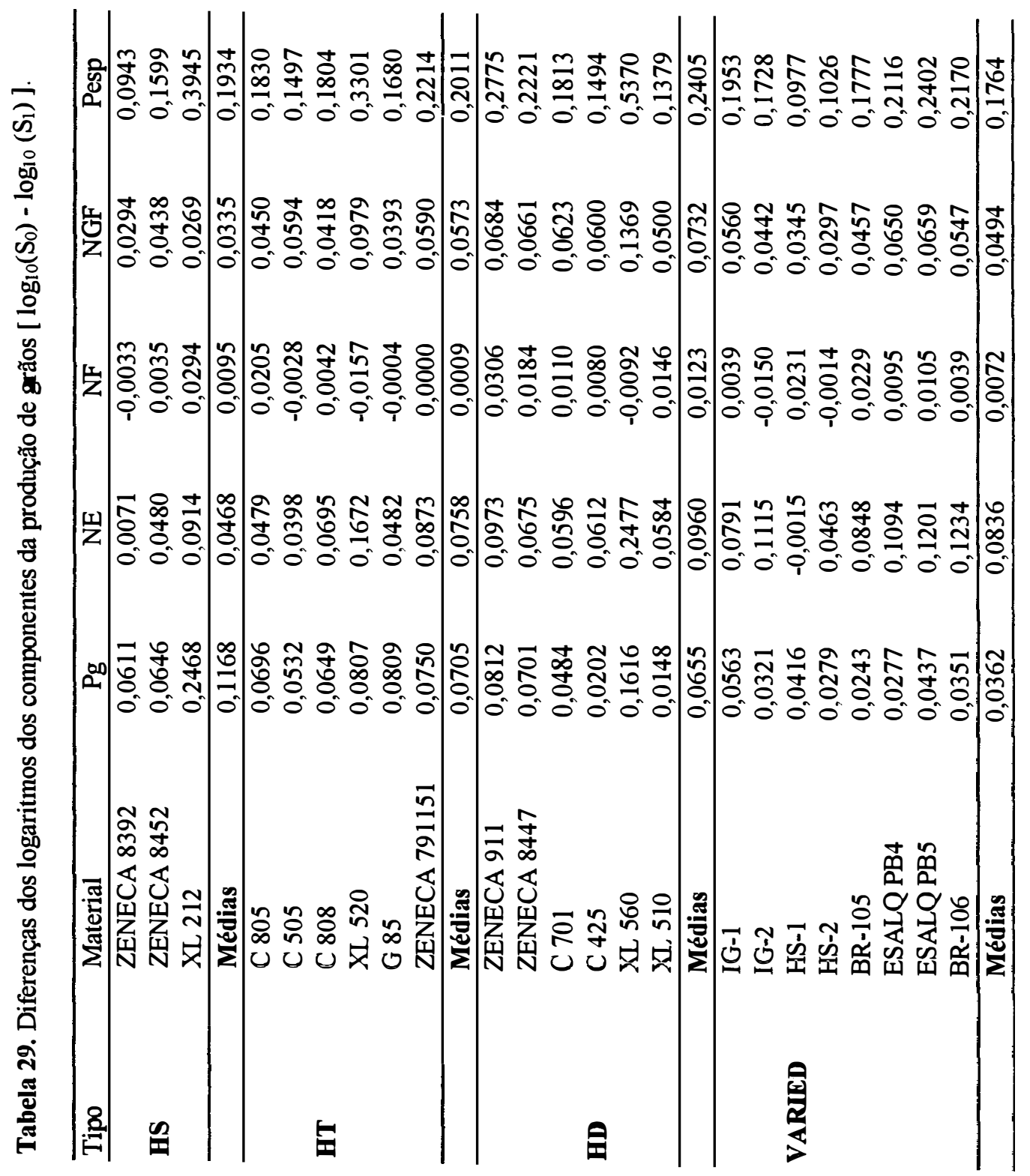




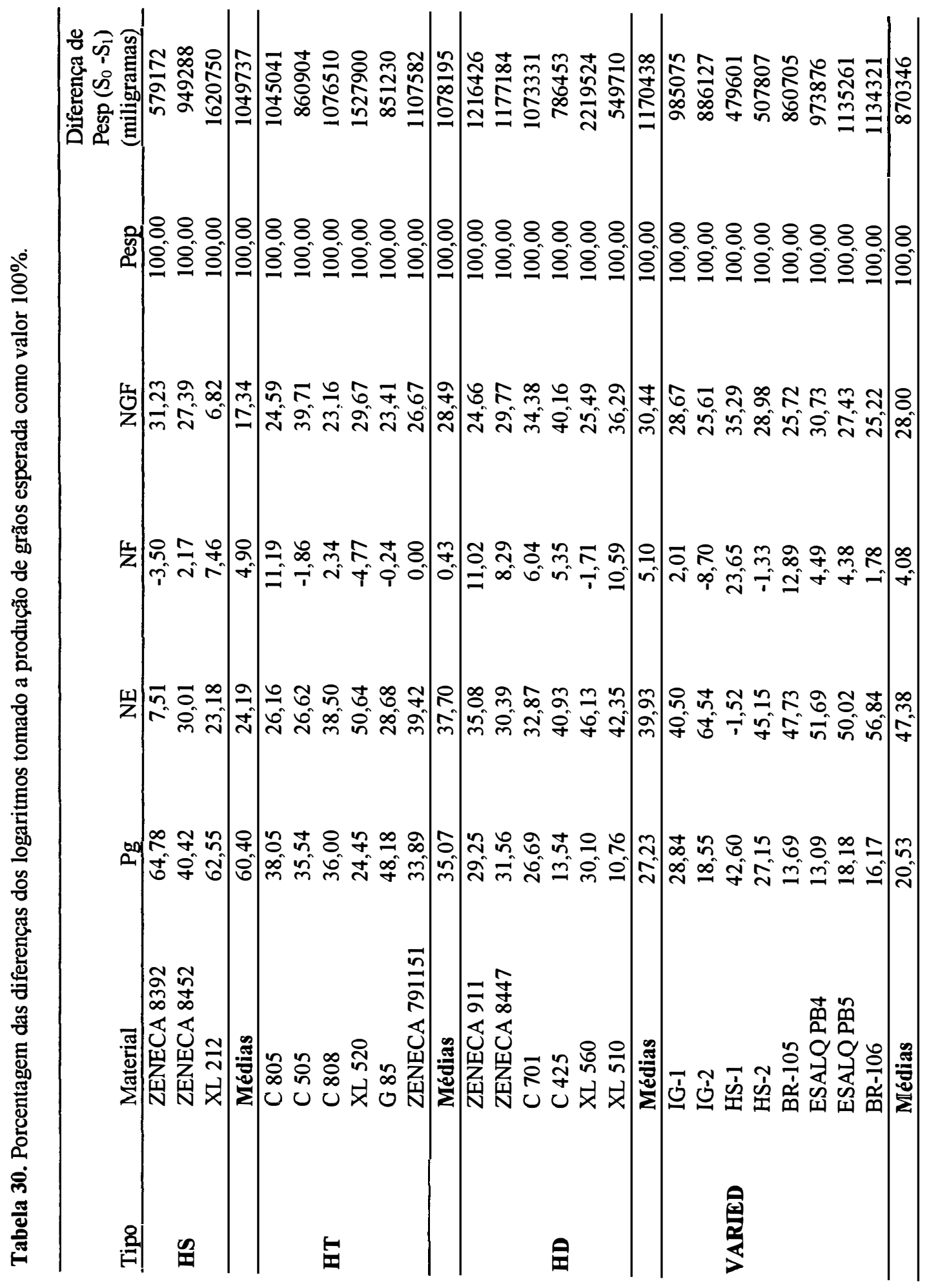

